\title{
WRR
}

SCIENTIFIC COUNCIL FOR GOVERNMENT POLICY

\section{A COMPARISON OF AMERICAN AND DUTCH IMMIGRATION AND INTEGRATION EXPERIENCES}

WHAT LESSONS CAN BE LEARNED?

Mirjam van het Loo, Stephan De Spiegeleire,

Gustav Lindstrom, James P. Kahan, Georges Vernez

The Hague, May 2001 


\section{THE MULTICULTURAL SOCIETY SERIES}

\section{Published titles}

J.D.J. Waardenburg, Institutionele vormgevingen van de islam in Nederland, gezien in Europees perspectief, WRR Werkdocumenten nr. W118, Den Haag.

Ingrid Esveldt en Jeroen Traudes, Kijk op en contacten met buitenlanders. Immigratie, integratie en interactie, WRR Werkdocumenten nr. W119, Den Haag.

Mirjam van het Loo, Stephan de Spiegleire, Gustav Lindstrom, James P. Kahan en Georges Vernez, A Comparison of American and Dutch Immigration and Integration Experiences. What Lessons can be Learned?, WRR Werkdocumenten nr. W120, Den Haag.

\section{Forthcoming}

J. Dagevos, Perspectief op integratie. Over de sociaal-culturele en structurele integratie van etnische minderheden in Nederland, WRR Werkdocumenten nr. W121, Den Haag.

Ruben Gowricharn, In- en uitsluiting in Nederland. Een overzicht van empirische bevindingen, WRR Werkdocumenten nr. W122, Den Haag.

Helga A.G. de Valk, Ingrid Esveldt, Kène Henkens en Aart C. Liefbroer, Allochtonen in Nederland. Een demografisch profiel, wRR Werkdocumenten nr. W123, Den Haag.

S. Verhallen et al., Nieuwe kansen voor taalonderwijs aan anderstaligen, WRR Werkdocumenten nr. W124, Den Haag.

Dennis Broeders, Immigratie- en integratieregimes in vier Europese landen, WRR Werkdocumenten nr. W125, Den Haag 


\section{PREFACE}

In continuation of its former reports relating to immigrant policy (i.e. 1979 and 1989) the WRR has initiated an new study on the multicultural society. This study particularly is concerned with the analyses and considerations as to the fact that the Netherlands has developed into an immigration country.

In the context of this project the WRR has asked several researchers to compile the information that is necessary for a solid empirical funding. One of the issues to be studied in this respect is the question to what extent Dutch experiences with immigration and integration can be compared to the experiences in the United States. To be more specific, the Council is interested in the question whether the Netherlands could gain some insights from the United States, being a country that has a lot of experiences with immigration processes. In the present study researches of RAND Europe make a binational comparison with respect to immigration and integration experiences, from which the Council may draw its own conclusions for Dutch government policy.

prof.mr. M. Scheltema

voorzitter WRR 


\section{CONTENTS}

Preface

Summary

1 Introduction

1.1 Background

1.2 Research questions

1.3 Set-up of the report

$2 \quad$ Methods

3

Bilateral comparison of immigration related issues

3.1 General issues

3.1.1 Locus of policy

Institutions responsible for immigration policy

3.1.3 Categories of immigration policy

3.2 Admission policy

3.2.1 Principles

3.2.2 Key issues

3.2.3 Statistics

3.3 Asylees and refugee

41

3.3.1 Prinicples

3.3.2 Criteria

Statistics

3.4.1 Principles

3.4.3 Statistics 53

3.5 Naturalization $\quad 54$

3.5.1 Principles $\quad 55$

3.5.2 Key issues $\quad 57$

3.5.3 Statistics $\quad 58$

3.6 Return migration $\quad 59$

3.7 Bilateral comparison of immigration related issues 60

$4 \quad$ Bilateral comparison of integration related

issues $\quad 63$

4.1 Education $\quad 64$

4.1.1 Key issues 66

4.1.2 Government policies $\quad 69$

$\begin{array}{lll}4.1 .3 & \text { Statistics } & 72\end{array}$

4.2 Employment $\quad 74$

$\begin{array}{lll}4.2 .1 & \text { Key issues } & 76\end{array}$ 
4.2.2 Government policies 78

$\begin{array}{lll}4.2 .3 & \text { Statistics } & 79\end{array}$

$4.3 \quad$ Social welfare $\quad 81$

$\begin{array}{lll}4.3 .1 & \text { Key issues } & 82\end{array}$

$\begin{array}{lll}4 \cdot 3.2 & \text { Government policies } & 82\end{array}$

$\begin{array}{lll}4.3 .3 & \text { Statistics } & 87\end{array}$

$\begin{array}{lll}4.4 & \text { Housing } & 88\end{array}$

4.4.1 Key issues $\quad 89$

$\begin{array}{lll}4.4 .2 & \text { Government policies } & 90\end{array}$

$\begin{array}{lll}4.4 .3 & \text { Statistics } & 92\end{array}$

4.5 Bilateral comparison of integration related issues 93

4.5.1 Education 93

4.5.2 Employment 93

4.5.3 Social welfare $\quad 94$

$\begin{array}{lll}4.5 .4 & \text { Housing } & 95\end{array}$

$\begin{array}{lll}5 & \text { Findings } & 97\end{array}$

$\begin{array}{ll}\text { Bibliography } & 107\end{array}$

$\begin{array}{ll}\text { List of abbreviations } & 111\end{array}$ 


\section{SUMMARY}

\section{INTRODUCTION}

The Netherlands Scientific Council for Government Policy (Wetenschappelijke Raad voor het Regeringsbeleid, WRR) asked RAND Europe to study American and Dutch experiences with immigrants, to analyze similarities and differences between these experiences, and to formulate points of special interest with respect to Dutch immigration policy, integration policy, and the relationships between these two. This report summarizes the approaches the governments of the two countries take, the key problems the United States and the Netherlands are facing with respect to immigration and integration, and the policies they have developed to deal with these problems.

Over the last decade, immigration flows into the Netherlands increased both in quantity and in diversity. This has created challenges for the Dutch government to formulate immigration and integration policies that reflect and balance the country's social, economic and humanitarian goals. Addressing these challenges is hampered by the poor understanding of the consequences of immigration.

Comparative studies can help improve understanding of the challenges, and in particular, some insights may be gained from looking at the American (and within the US, especially the California) experience. Both countries have experienced a large recent influx of immigrants, and governments in both countries struggle with similar problems, albeit sometimes in very different ways. Therefore, we aimed in this project to study similarities and differences between the Dutch and the American experiences with respect to immigration and integration, and to draw conclusions from this binational comparison that lead to points of special interest for Dutch government policy.

In close co-operation with WRR, we identified the following issues in the field of immigration:

- Overall policy categories;

- Admission policy;

- Asylees and refugees;

- Illegal immigration;

- Naturalization; and

- $\quad$ Return policy.

With respect to integration, we focused primarily on topics within the fields of:

- Education;

- Labor market;

- Social welfare; and

- Housing. 


\section{SOURCES}

We identified which challenges the Netherlands is facing with respect to immigration and integration by doing desk research (government reports, websites, etc.) and by conducting a small number of targeted interviews with policy makers within the Dutch government. We consulted available sources to examine the effects of these policies on the immigrant experience. Sources of information include government reports, research reports, key books, articles and websites, and statistical databases of national and international organizations that collect data on migration (e.g. us Census Bureau, Centraal Bureau voor de Statistiek, and UNECE).

\section{BILATERAL COMPARISON OF IMMIGRATION RELATED ISSUES}

\section{Control of immigration}

In the us, immigration policy decisions (who enters the us and in what numbers) are made, controlled and enforced by the federal government. Many integration policies (how to integrate immigrants into the American population and assist them with public benefits during the transition), on the other hand, are made at the state level. The tension between these two interconnected issue areas has led to frequent problems between the federal government on the one hand, and state and local governments on the other. In the Netherlands, immigration policy decisions are made, controlled and enforced by the national government. Integration policy decisions are mainly made at the national level. However, in the foreseeable future we are likely to witness a recalibration of the concept of subsidiarity in immigration as the European Union becomes more integrated.

\section{Institutions responsible for immigration policy}

In the US, the Immigration and Naturalization Service (INS) is responsible for administering and enforcing virtually all immigration laws. In the Netherlands, the Immigration and Naturalization Service (IND), a division of the Ministry of Justice, has the corresponding role, although other agencies reporting to the Ministries of Defense and Home Affairs also have roles.

\section{Categories of immigration policy}

We distinguished among the shaping, admissions and enforcement components of immigration. In the US, shaping the mixture of the immigration flow is largely implicit, although recent policy especially with regard to Mexico and Central America has aimed at improving conditions in these countries in part to reduce the demand to immigrate to the us. In the Netherlands, shaping is less well-developed, and instead, there is an explicit returns policy (absent in the us) to induce foreigners resident in the Netherlands to return to their home countries. 
US control of the admission component is highly regulated and commences in the home country, with visa requirements and agreements with transport companies. Once inside the us, foreigners can sometimes, again in highly regulated ways, change category from non-immigrant to immigrant. Policy in the Netherlands is similar, with the important exception of respecting the right of free movement of persons within the European Union.

The enforcement category is the most important category of us immigration policies, with the lion's share of the budget and effort being dedicated to enforcement at the borders. The Netherlands has a very different policy, with border control never a large priority and assuming even lesser importance after the implementation of Schengen. Internal control, including registration by the Aliens Police and municipal registration of foreigners, is the main component of a relatively minor enforcement category.

\section{Openness to 'regular' immigration (i.e., not refugees or asylum seekers)}

The us has a restrictive immigration policy, in which prospective immigrants have to satisfy a number of requirements before they can be lawfully admitted to the us. These requirements include a system of numerical quotas and preferences, of which the most important policies are those of family reunification and restriction of illegal immigration. Family preferences and employment-based preferences are both codified in detailed priority lists. The Netherlands also has a restrictive immigration policy (within the constraints of European Union rules), although quotas and strict priorities do not exist. Preferences are also for family reunification and (to a lesser extent than previously) acquisition of skilled labor.

In implementing immigration policy for regular immigrants, key issues in the us include more efficient processing of applications and ineffective enforcement. Matters regarding the absolute number of immigrants have a lesser place, although selectivity of immigrants can from time to time become a topic for public debate, especially as this relates to labor needs. The dilemmas resulting from the automatic granting of citizenship to children born in the Us no matter what the status of their parents has also been discussed, but would take a Constitutional amendment to change - never an easy step. In the Netherlands, there is a similar key issue on the efficiency of the immigration bureaucracy, in particular the backlog of processing applications and the perceived occasional arbitrariness of IND decisions.

\section{Asylees and refugees}

Asylees and refugees play an important role in immigration policy. The two differ only in the place where a person asks for the status - asylum being asked for once a person has landed in the country and refugee status being asked for outside the borders. 
Both the us and the Netherlands offer asylum and refugee protection to qualified applicants who are unable or unwilling to return to their country of nationality because of persecution or a well-founded fear of persecution, based on at least one of five internationally recognized grounds: race, religion, ethnicity, membership in a particular social group, or political opinion. Once granted entry, people are allowed to live and work in the country. Eligibility is decided on a case-by-case basis. Although the processes for admission of asylees and refugees are largely similar in the two countries, the proportion of immigrants in these classes (both in terms of percentage of immigrants and size of this group compared to the total population of the country) is much greater in the Netherlands than it is in the Us; hence policies concerning this class are much more a subject of consideration in the Netherlands. The us has quotas for admissions, both in total number and according to nationality group. The Netherlands does not have quotas, but decides on a periodic basis which nationalities or ethnic groups qualify as asylees or refugees.

\section{Illegal immigration}

This class of immigrants poses specific challenges to the receiving country, and therefore deserves specific attention. The us has a high number of illegal immigrants and this issue drives much of immigration policy. A high proportion of the entire immigration budget is border enforcement aimed at interdiction and deterrence. The problem is much less evident in the Netherlands (although the exact prevalence is unknown); detection is through internal (residence registration and employment) means. In both countries, there is some thought of reducing illegal immigration by reducing incentives in the home country to immigrate. In the Us, this is part of the reasoning behind NAFTA and other economic levers; in the Netherlands, it is expressed through foreign aid and investment and a returns policy. Both the us and the Netherlands have or have had in essence a statute of limitations, whereby illegal immigrants who have resided in the country a sufficient amount of time can become open and obtain legal immigration.

\section{Naturalization}

Becoming a citizen is the last step in immigration (although not necessarily in integration, as will be seen). Both the us and the Netherlands make it relatively easy for a legal immigrant to become a citizen after a period of time as a permanent resident. Differences reside in two areas: dual citizenship and automatic status for children born of non-citizens. The us does not require persons taking us citizenship to relinquish citizenship in other countries, although it does not encourage that practice. The Netherlands currently makes that demand (although in the past it has not made the demand or not enforced it). Children born in the United States are automatically us citizens, while only children born of Dutch parents are automatically Dutch citizens. In the us, the naturalization process was regarded as cumbersome and time-consuming, but the average processing time has recently fallen from 27 months to 12 months. In the Netherlands, this has not been an issue. 


\section{Return migration}

The Dutch have a policy not found in the us of return migration - that is stimulating immigrants to the Netherlands to return to their home country by providing economic incentives. This is a policy in part derived from a desire to limit the number of immigrants and in part to better living conditions in other countries.

\section{BILATERAL COMPARISON OF INTEGRATION RELATED ISSUES}

Integration refers in this report to how immigrants fare in education, the labor market, social welfare, and housing, compared to natives. Although integration also comprehends acceptance, discrimination, and political participation, these factors fall outside the scope of this current study. In both the Netherlands and the Us, policies are in place in diverse areas relating to integration not only of immigrants, but also of different segments of society to which immigrants often belong. Although such broader policies can have a strong effect on immigrants, they are generally not designed with immigrants in mind. Here, we will consider such policies when the effect on immigrants is particularly important.

Responsibilities for integration of immigrants in both the Netherlands and the US do not only rest with the national government. In the Us, the federal government plays only a minor role in integration; in the Netherlands, the national government has the most important role, but provinces and municipalities are also involved. It is outside the scope of this project to describe all integration-related activities of subnational governments, but where state responsibilities in the us correspond to national responsibilities in the Netherlands, we will look to California.

\section{Education}

In the us, immigrant children and youths are as likely as natives to enroll in primary and middle schools, are somewhat less likely than natives to attend high school and beyond. This is not entirely 'dropping out', but more a matter of never 'dropping in'. However, this is strongly conditioned on ethnic origin - Hispanics do markedly less well than other immigrant groups. There is evidence that problems are due in large part to language problems; the better the ability to speak English, the less the problem. Consequently, there is pressure to increase the number and quality of English as a Second Language courses and programs. In the Netherlands, there is special concern about the relatively high percentage of people leaving secondary school without any qualifications, especially among certain ethnic groups. Here, though, immigrants are not particularly distinguished from citizens of these ethnicities. Again, language is singled out as a major source of problems.

Both countries have teacher shortages and concerns about class size and the quality of education, but these are not related to integration (although they influence integration to the extent that immigrants differentially feel the effects of these 
problems). There is evidence that starting schooling behind is not easily remediated by 'catch up' programs; hence there is a focus on improving quality at the earliest stages of education.

Both countries have forms of immigrant education programs that are relatively small in scale and administered by local agencies (but partly or totally funded by the national government).

\section{Employment}

After education, employment is the other big issue for regular immigrants. In the us, the unemployment rate was mildly higher for the foreign-born labor force as a whole compared to the native labor force; for the Netherlands, this difference is significant and major. This is in spite of strong requirements for labor permits and the likelihood of occupation for immigrants to the Netherlands.

On the demand side of employment, both countries attempt to fill critical shortages of skilled labor in certain sectors through immigration, although whether this is an advisable policy is debated in both countries, given an 'immigrants should not displace native-born workers' philosophy.

Once legally in the Us, immigrants may obtain job training available to other residents, but there are no programs targeted to immigrant job training. The Netherlands, on the other hand, has a special law to help immigrants obtain training and find jobs.

\section{Social welfare}

A relatively high use of social welfare programs is often considered to be a sign of poor integration in society. In the us, some welfare programs are used relatively intensely, while others are relatively little used. This is in part because of eligibility requirements for such programs, which often have work history or other requirements not possessed by immigrants, and is also a reflection of the principle in the Us that immigrants (or anybody else, in some views) should not become public charges. Also, because authority to determine immigrants' access to social welfare programs has devolved to the states, there are significant differences among states. California, for example, is a leading state in the provision of benefits, while Texas is one of the trailing states, even though both rank high in the proportion of (especially Hispanic) immigrants entering. In the Netherlands, by contrast, there is a relatively high use by immigrants, especially non-western foreigners, of the whole range of public benefits. Asylum seekers are singled out for special benefits in this regard.

\section{Housing}

Like social services, housing is less an immigration issue than a racial minority issue in the us Statistics there are based upon ethnic group, and show significant discrimination, especially among disadvantaged groups. Government policy, while limited by a general principle of the rule of the market, are based upon civil rights 
and social efforts to improve poor communities. Housing assistance is available in limited degree. Immigrants are not generally considered part of the overall housing problem, although undoubtedly some of them (especially illegals) lack housing. In the Netherlands, most non-western foreigners live in the four big cities in the western part of the country, and usually within specific parts of these cities. This concentration is in spite of programs to diversify communities. Asylum seekers in the Netherlands are entitled to housing as part of the asylum granting process.

Home ownership is a particular Dutch issue, with non-western foreigners owning homes at 30 percent of the rate of natives or western foreigners. The Us statistics show a similar, but not as extreme, pattern.

\section{FINDINGS}

\section{Three populations of immigrants $=$ three flavors of policy}

The objective of the present project was to compare the immigration and integration policies of the Netherlands and the Us. A first finding of our review of the information is that there is no 'policy' for newcomers to either country. Instead, there are different, sometimes overlapping, policies for addressing three separate populations of people who desire to relocate to a new country: 'regular' legal immigrants, refugees and asylees, and illegal immigrants. For example, asylees and refugees number proportionally far more in the Netherlands than in the us, and it is this category that often presents the greatest need for integration. Therefore, a magic bullet for best immigration and integration practices cannot be derived from a comparison between the us and the Netherlands.

\section{American and Dutch approaches towards immigration and integration}

There are, however, a few overall generalizations that are useful to mention. One difference between the two countries is in the underlying attitude towards citizenship. Americans view their country as the land of opportunity; us citizenship is viewed more than Dutch citizenship as a privilege. The Dutch might consider easing somewhat the restrictions on obtaining Dutch citizenship in order to better compete in obtaining immigrants who can add value to Dutch society. A concrete example of this is the question of dual citizenship, currently officially not permitted in the Netherlands; relaxing this restriction might increase immigration of skilled workers.

In the us, immigration policy is entirely governed at the federal level while integration is largely left to the states. By contrast, in the Netherlands the policies on both immigration and integration are designed at a national level and are pretty much consistent throughout the country. Even when specific programs are implemented at the provincial or municipal level, the source of the funding is likely to be national. However, with growing European unification, there is discussion about some of the immigration policies moving up to a supranational policy level. 
The American experience urges caution here - separation of authority for immigration and responsibility for integration can yield discontinuities in policy that do not serve newcomers well.

The American attitude towards welfare is different from the Dutch and leads to differences in integration. Welfare in the us is widely regarded as a fall-back position and is not offered readily to newcomers. In the Netherlands, on the other hand, admission as a resident to the country carries the implication that the newcomer is now part of Dutch society, and therefore entitled to the full set of benefits all members of society may obtain. Our examination of American versus Dutch statistics on some measures of integration (e.g., unemployment, home ownership, engagement in higher education) showed that in spite of many integration programs, the Dutch might be viewed as lagging behind the Americans in integration. However, this conclusion is based upon aggregated statistics across all three of the Dutch immigrant populations compared to the largely regular us immigrant population. Better breakdowns of Dutch immigrant groups and studies of factors facilitating or impeding integration are needed before one could conclude that Dutch integration efforts are ineffective or counterproductive.

In both the Netherlands and the us, a number of social programs for disadvantaged native minorities are available to immigrants; these (e.g., bilingual education, supplementary money for schools in poor neighborhoods, job training programs) often are major sources of integration. What is not known is the extent to which these general social programs are effectively designed for the specific needs of immigrants. For such programs with a heavy proportion of immigrant use, needs assessments and evaluations could help illuminate where integration could be made more efficient.

\section{Immigration and integration policy should be linked more closely}

The relationship between immigration and integration policy works in two directions. The interconnecting nature of these two forms of policy implies that they should be linked. Both in the Netherlands and the Us, immigration and integration are managed by different (sets of) organizations. A closer linking of immigration and integration policy would, in our view, improve the potential for policy planning, especially in the field of integration.

\section{Regular immigrants}

The Dutch and the Americans approach the issue of regular immigrants from slightly different perspectives, but in the end, there are many similarities in the policies that are employed in their immigration and integration. In both countries, the entry of regular immigrants is highly regulated. Regular immigrants are generally not viewed as social problems in either country - at least status as an immigrant is not viewed as an element of the problem. 
The recent debate in the Netherlands on the use of immigration policy as a tool to attract needed human capital (critical skills) has already yielded some important policy initiatives, such as relaxing the entry of skilled labor in areas of acute demand. This is indeed an adoption of the us policy regarding the immigration of skilled labor. Perhaps, what is needed is a consolidation of this policy through enhancing and streamlining the ways in which it is implemented (e.g. through quotas, auctions, etc.).

Although Dutch foreign and security policy affects migratory flows, the Dutch external relations apparatus does not appear to have a direct function with respect to immigration policy. More explicit integration of the 'shaping' factor (a direction the Us State Department seems to be taking) in overall immigration policy, and in the country's (and European) foreign policy in particular, could be of some interest to Dutch policymakers.

Many people come to both the Netherlands and the us for a temporary stay of several years duration, either to attend educational institutions or to fill critical jobs. Some of these people desire to remain and become immigrants. The us and Dutch policies differ in this regard, especially in helping valued temporary visitors become permanent residents. In particular, the Dutch have a return policy that is completely unknown in the Us. What is true of both countries is that the policies regarding who should or should be encouraged to return home are inconsistent; a rethinking of these policies would probably be of benefit.

\section{Asylees and refugees}

Compared to the us, the Netherlands admits many more refugees and asylum seekers. Caring for these immigrants is therefore the dominant issue in the Dutch immigration debate, and a number of the integration policy tools have been formulated with this group specifically in mind. The us provides more guidance and services for the integration of asylees and refugees than for any other population of immigrants. This said, the American effort falls far short of that of the Netherlands. However, given the relative size of the proportion of asylees and refugees in the total immigration in the two countries, we are hesitant to recommend that either can provide exemplary practices for the other.

It is widely viewed that some people seek refugee or asylum status in order to immigrate to the Netherlands because other avenues for immigration are not open to them. Dutch policy holds that the entry of asylees and refugees should not be linked to the immigration needs of the receiving society, nor should it be restricted by any problems of reception capacity. However, in view of the perceived problem, there is a need for a better understanding of the links between asylees and refugees on the one hand and regular immigration on the other hand, and a policy that is based upon this understanding. 


\section{Illegal immigrants}

The question of illegal immigration dominates the us debate. In the Netherlands, illegal immigration is a lesser concern, but not entirely absent. Predicting the extent of illegal immigration and controlling it pose difficulties for the Dutch government, and the us experience offers more in the way of negative object lessons than practices to alleviate the problem.

\section{The limits to immigration and integration policy}

Immigration and integration policy react to external developments that are difficult, if not impossible to control. In the conduct of our research, several developments were mentioned during the interviews or found in the literature that might lead to reconsiderations of the us and Dutch immigration and integration policies. Examples of such developments are:

- The state of the world: The number of people applying for admission to a specific country is strongly influenced by the number and size of armed conflicts, natural disasters, hunger, or turbulent political instabilities in the world.

- Economic developments: The economies of most countries with a positive net migration are currently doing very well. A period of economic downturn might lead to reconsideration of the practices and principles of both admissions policies and efforts to integrate newcomers.

- Pace of European unification: Increasing European integration, both in terms of number of countries and supranational authority, leads to questions with respect to the division of responsibilities for immigration and integration.

- Aging of the population: The changing demographics threatens to lead to a situation in which there are not enough workers to pay for retired people's pensions. Whether immigration can or should be offered as a solution to this problem requires analysis and discussion.

\section{Toward the assessment of immigration and integration policies}

Although both countries have done remarkably little systematic evaluation of the effectiveness or efficiency of various immigration-related policies, there appear to be more holes in the state of the art on the impact of immigration in the Netherlands than in the us. Both the us and the Netherlands have experienced an explosion in public expenditures on immigration. But surprisingly enough, there are remarkably few studies on the effectiveness and the efficiency of those expenditures. The analyses that have been performed suggest that the increased expenditures have not produced a commensurate improvement in performance in either country.

The meaning of integration is subject to differences of opinion. There are no commonly accepted measures of successful integration. A broad definition of successful integration would be that it is no longer possible to distinguish the immigrant population from the native population. Integration has both social-structural (such as education, employment, social welfare and housing) and social-cultural dimen- 
sions (such as acceptance, discrimination, and political participation). As the various integration policies affect different dimensions of integration at the same time, it is very difficult to measure the effects of single policies. Our analysis showed that a one-to-one matching of policies and outcomes was not possible. This is not only because of context effects, but because adequate information for teasing out likely effects of single policies from the combined effects of the entire package of policies is not possible.

Another complicating factor is that integration takes place over a generation at a minimum. Integration is, by definition, a process that cannot take place from one day on the next. Therefore, it is difficult to determine after which period of time the effectiveness of integration policy should be assessed. Both the us and the Netherlands face a continuous and ever more diverse influx of immigrants and successful integration of these immigrants cannot be expected on short term. It would be valuable to develop measures for integration that could be used across countries and across generations of immigrants. Improved monitoring of integration processes in different countries might make it easier to define best practices of integration. Based on the currently available information, it is hardly possible to measure to which integration policies are effective.

We believe that the Netherlands could benefit from examining the us approach to the collection and analysis of information regarding immigration and integration, and indeed going a step further than that to develop new measurements of policy effectiveness. This effort would not only be of practical benefit in the assessment of current policy, but it would be an impetus for making more explicit what the goals of immigration and integration policy are. If policy goals are made more explicit, then the public debate can be conducted on more of a rational basis. This, in turn, can lead to the development of policy tools whose chances of success are increased. 


\section{INTRODUCTION}

\subsection{BACKGROUND}

Over the last decade, immigration flows into the Netherlands increased both in quantity and in diversity. Currently, approximately 17 percent of the people living in the Netherlands are of foreign origin ${ }^{1}$ and approximately 10 percent of the people living in the Netherlands belong to what are termed 'ethnic minority groups'2 . According to a prognosis of the Central Bureau of Statistics, these percentages will double in the next 15 to 20 years. The increasing proportion of foreigners in the Dutch population and the increasingly diverse composition of this group poses major challenges to Dutch society in general, and to policy makers in particular.

One of the major challenges for the Netherlands in this context is to formulate immigration and integration policies that reflect and balance the country's social, economic and humanitarian goals. Many of the consequences of the recent immigration into the Netherlands remain poorly understood - even important ones, such as its net fiscal and economic impact. There have been surprisingly few systematic attempts at developing 'best practices' in various fields of immigration and integration policy. There is little understanding of the complex interplay among the various policies (e.g. between asylum policy and regular immigration policy; or between immigration and integration policy).

The Netherlands, however, is not alone in facing these challenges. Similar challenges are faced by a large number of other countries, such as the United States, Canada, Australia, New Zealand and most European Union countries. Social scientists in these countries have accumulated an impressive body of findings on various aspects of the immigration phenomenon, although these studies tend to be uneven across immigration aspects and across countries. Significant knowledge gaps remain and many of the findings fail to be systematically introduced into the policy debate.

We are of the firm belief that comparative studies in the field of immigration can yield the systematic knowledge that is required to improve this part of public policy, whose importance will only increase in the decades to come. To give an impetus in this direction, this exploratory report has examined and compared key aspects of the immigration experiences in the Netherlands and the United States (US). Because of integration in the US is a matter left largely to the states and because it is the state with the largest influx of immigrants, we will focus the American part of the comparison on California.

The immigration experience of the us in general, and California specifically, is interesting to the Netherlands for a number of reasons. Both countries have experienced a large recent influx of immigrants, towards which they appear to have a fairly ambivalent attitude. On the one hand, there is a feeling that the influx is becoming increasingly problematic, partly because it is widely believed that immigrants impose fiscal 
costs on local and national budgets, partly because of concerns over the impact of immigration on the local Labor market, and partly because the ethnic, racial, or religious composition of the immigrants raises issues about acculturation. On the other hand, both countries have self-images that, while fundamentally different, still share a concept of openness and shelter.

In addition to these general similarities, California experiences in this field may be of interest to the Dutch debate because the effects of its integration policies are relatively well studied. RAND has over the past decade generated significant policy insights in this field (McCarthy and Vernez 1997; McCarthy and Vernez 1998) that this report attempts to synthesize with an eye towards Dutch policy concerns and interests.

The Netherlands Scientific Council for Government Policy (Wetenschappelijke Raad voor het Regeringsbeleid, WRR) has asked RAND Europe to study American and Dutch experiences with immigrants, to analyze similarities and differences between these experiences, and to formulate points of special interest for Dutch immigration and integration policy. This report focuses entirely on the approaches the governments of the two countries take, and does not include information on any private sector initiatives, e.g. activities of NGO's, focusing on immigrants.

The RAND Europe study is an input to an ongoing WRR study on developing new views to cope with immigration and integration related problems. The aim of the wRR study is to provide the building blocks for a policy that primarily assumes a permanent inflow of foreigners and an increasing diversity - in ethnic, cultural and socio-economic respects - of those who wish to settle in the Netherlands.

\subsection{RESEARCH QUESTIONS}

The aims of this project were (1) to study similarities and differences between the Dutch and the American experiences (with an emphasis on California) with respect to immigration and integration, and (2) to draw conclusions from this binational comparison that lead to points of special interest for Dutch government policy. For both the us and the Netherlands, we addressed the following questions:

- What are policies with respect to immigration, integration, and social support for immigrants? Which policy instruments are used to influence immigration flows and to stimulate integration? To what degree do the policies and policy instruments used differ between the two countries?

- What is the context within which these policy instruments are used, and to what degree do similarities between the two exist?

- What are the socio-economic characteristics of immigrants (e.g. age and sex, nation of origin, education, and economic status and economic mobility)? 
- What are the characteristics of relevant aspects of the California and Dutch society (e.g. economic situation, labor markets, and education system)?

- How did the immigrants fare in their new home country? We specifically focus on the social-structural dimension of integration (education, labor market, social welfare, and housing). Although important, social-cultural issues of integration (such as acceptance, discrimination, and political participation) fall outside the scope of this study.

- What is the relationship between government policies, the context in which these instruments are implemented, and the effects of immigration on both the immigrant population and the native population of the receiving countries? Examples of more specific issues addressed are:

- $\quad$ the relationship between immigration policy and integration policy

- the facilitators and barriers to integration of immigrants

- the role of social welfare arrangements in the immigration debate

- What lessons can we learn from comparing the California with the Dutch experience? What does this mean for Dutch policy?

\subsection{SET-UP OF THE REPORT}

In Chapter 2, the methodology of the study is briefly described. Chapters 3 and 4 describe the results of the binational comparison of immigration and integration related issues, respectively. These chapters present key information on immigration and integration related problems and government policies in both the us and the Netherlands in short synoptic tables summarizing the respective us and Dutch policies and experiences and highlighting some of the most interesting observations. These synoptic tables are broken down by policy issues and are supplemented by brief descriptions of both cases and by a presentation of the most relevant statistics. In preparing these materials, our priority was on policy relevance for Dutch immigration policy, rather than on any attempt at exhaustiveness. Chapter 5 briefly describes our findings of this binational comparison in terms of possible policy implications for the Dutch. 


\section{NOTES}

1 The broad definition of people of foreign origin as used by the Centraal Bureau voor de Statistiek is that people of foreign origin are people of whom at least one of the parents was born outside the Netherlands.

2 Ethnic minorities are defined as people from non-western foreign origin. 


\section{METHODS}

This chapter briefly describes the methodology of the study. It describes what steps were taken to answer the research questions and how information was collected.

Task 1: Identification of the main policy issues faced by Dutch policy makers with respect to immigration and integration

The first task was to identify which challenges the Netherlands is facing with respect to immigration and integration that this study will address. The needed information was collected by doing desk research (government reports, websites, etc.) and by conducting a small number of targeted interviews with policy makers within the Dutch government. In close co-operation with WRR, we identified the following issues in the field of immigration:

- $\quad$ Overall policy categories;

- Admission policy;

- Asylees and refugees;

- Illegal immigration;

- Naturalization; and

- $\quad$ Return policy.

With respect to integration, we focused primarily on topics within the fields of:

- Education;

- Labor market;

- Social welfare; and

- Housing.

Task 2: Comparative study on immigration and integration policies

Within the context of the foci identified in Task 1, we summarized the main elements of Dutch and American policy on immigration and integration. We consulted available sources to examine the effects of these policies on the immigrant experience. Sources of information include government reports, research reports, key books, articles and websites, and statistical databases of national and international organizations that collect data on migration (e.g. Us Census Bureau, Centraal Bureau voor de Statistiek, and UNECE). The task resulted in an overview of what we know and what we do not know about immigration and integration, as described in chapter 3 and 4 of this report.

\section{Task 3: Analysis of the available information, resulting in points of special interest for Dutch policy makers}

We compared Dutch and us government policies, the context in which these policies are implemented, and the effects of immigration on both immigrants and the people in the receiving countries. This task yielded points of special interest for the Dutch policy on immigration and integration. 


\section{BILATERAL COMPARISON OF IMMIGRATION RELATED} ISSUES

This chapter focuses on the most important aspects of immigration policy. It starts off sketching the general framework of immigration policy, i.e. it describes the three main components of immigration policy, and the institutions responsible for it. The other sections in this chapter deal with more specific aspects of immigration policy, including admission of regular immigrants, admission of asylees and refugees, illegal immigrants, naturalization, and return migration. Each section describes the key problems, the policies that are being implemented to address those problems, and, where possible, the effects of these policies. In addition, some statistics are included to give an impression of the similarities and differences between the us and the Dutch situation.

Section 3.2 discusses the admission of immigrants: it describes the main principles of admission policy, the categories of immigrants who are admitted, the criteria that potential immigrants need to meet, key issues related to admission policy, and some statistics on admitted immigrants. The main focus will be on permanent immigration. However, some attention will also be paid to temporary immigration, because temporary migration creates both opportunities (e.g. temporary labor migration to fill job vacancies) and threats (e.g. people overstaying their permits) for the receiving society. Additionally, some temporary immigrants become permanent ones.

Section 3.3 focuses on the admission of a specific class of immigrants, namely asylees and refugees. This class needs specific attention because admission policy for asylees and refugees is significantly different from admission policy for regular immigrants. Important differences exist with respect the main principles of admission policy, the criteria for admission, and the key problems with respect to admission. As we will see in chapter 4 and 5 , this not only has implications for immigration, but also for integration of immigrants into the society.

Section 3.4 focuses on illegal immigration, the related enforcement policy, the rights of illegal immigrants and the key problems related to illegal immigration. Section 3.5 describes the policies related to naturalization of immigrants and the key problems associated with naturalization. Specific issues discussed are dual nationality and the nationality of children born to immigrants. Finally, section 3.6 focuses on return migration, a policy option that is well accepted in the Netherlands, but non-existent in the Us. 


\subsection{GENERAL ISSUES}

Section 3.1 focuses on some general issues with respect to immigration policy. It describes at which level of government immigration policy is developed. In addition, it discusses the institutions that are responsible for these policies and focuses on major policy categories. In the table below, a comparison of the key aspects of the Dutch and American immigration policy is made. The remainder of this section discusses these issues in more detail.

\section{Table $3.1 \quad$ General issues}

\begin{tabular}{|c|c|c|c|}
\hline Topic & The Netherlands & United States & Remarks \\
\hline Locus of policy & $\begin{array}{l}\text { National, but with } \\
\text { important European } \\
\text { component }\end{array}$ & National & \\
\hline $\begin{array}{l}\text { Responsible } \\
\text { institutions }\end{array}$ & $\begin{array}{l}\text { Ministry of Justice (IND), } \\
\text { Ministry of Foreign Affairs } \\
\text { Ministry of Defense }\end{array}$ & $\begin{array}{l}\text { Department of Justice } \\
\text { (INS), State Department; } \\
\text { Department of Labor; } \\
\text { Department of Health } \\
\text { and Human Services }\end{array}$ & $\begin{array}{l}\text { INS is responsible for both } \\
\text { processing of applications } \\
\text { and enforcement. IND is } \\
\text { only responsible for appli- } \\
\text { cations; Royal Mare- } \\
\text { chaussee is primarily res- } \\
\text { ponsible for enforcement. }\end{array}$ \\
\hline Policy categories & $\begin{array}{l}\text { Limited deliberate } \\
\text { shaping*; } \\
\text { Great emphasis on } \\
\text { admission procedure } \\
\text { Limited enforcement }\end{array}$ & $\begin{array}{l}\text { Some deliberate shaping* } \\
\text { Important emphasis on } \\
\text { admission procedure } \\
\text { Great emphasis on } \\
\text { enforcement }\end{array}$ & $\begin{array}{l}\text { Both countries put em- } \\
\text { phasis on the admission } \\
\text { procedure; us puts more } \\
\text { emphasis on enforcement } \\
\text { (mainly at the border) } \\
\text { than the Netherlands } \\
\text { (where enforcement } \\
\text { mainly takes place inside } \\
\text { the country). }\end{array}$ \\
\hline General principles & $\begin{array}{l}\text { main pillars: } \\
\text { Limit immigration } \\
\text { Fight discrimination } \\
\text { Stimulate integration } \\
\text { Stimulate return } \\
\text { migration }\end{array}$ & $\begin{array}{l}2 \text { main pillars: } \\
\text { Limit general immigra- } \\
\text { tion, while stimulating } \\
\text { selective immigration } \\
\text { Fight discrimination (not } \\
\text { immigrant-specific) }\end{array}$ & $\begin{array}{l}\text { In US, a key principle is } \\
\text { family reunification } \\
\text { (where family is defined } \\
\text { broadly beyond the nu- } \\
\text { clear family); Netherlands } \\
\text { has a return policy }\end{array}$ \\
\hline
\end{tabular}

* For a definition of 'shaping', see below.

\subsubsection{LOCUS OF IMMIGRATION POLICY}

In the Us, immigration policy decisions (who enters the us and in what numbers) are made, controlled and enforced by the federal government. Many integration policies (how to integrate immigrants into the American population and assist them with public benefits during the transition), on the other hand, are made at the state level. The tension between these two interconnected issue areas has led to 
frequent problems between the federal government on the one hand, and state and local governments on the other. States have grown increasingly angry at what they see as an unfair financial burden placed on them by a federal government that is unwilling to enforce its immigration laws. Several measures to deny state and local government services to illegal immigrants are prompted by the rising cost of services paid for by state taxpayers.

In the Netherlands, immigration policy decisions are made, controlled and enforced by the national government. Integration policy decisions are mainly made at the national level. However, local governments have the right to develop and implement integration policies, in addition to the policies designed at a national level.

For the foreseeable future, we are likely to witness a continuing recalibration of the concept of subsidiarity in immigration issue, as European countries try to define exactly which aspects of immigration policy are best dealt with at the European level, which at the national, and which even at the subnational level.

\subsubsection{INSTITUTIONS RESPONSIBLE FOR IMMIGRATION POLICY}

Table 3.2

Overview of governmental organizations handling immigration/ integration issues

\begin{tabular}{|l|l}
\hline Federal Agency & Main functions \\
\hline INS (Department of Justice) & Process immigration/refugee/asylum applications \\
& Naturalization \\
& Enforcement (border and interior) - with some involve- \\
& ment of Customs and the Treasury Department \\
& Initial screening of immigrant applications \\
& Provide visitor visas \\
& Negotiate bi/multilateral agreements \\
Department of Labor & Employer certification for visas \\
Department of Health and Human Services & E.g. provide and enforce programs targeting \\
& immigration \\
\hline No one agency has the lead role in formulating immigrant policy.
\end{tabular}

Typically, initiatives for changes in immigration policy have been proposed by Congress.

The primary mission of the Immigration and Naturalization Service (INS) is to administer and enforce the nation's immigration laws. INS activities include: determining the admissibility of persons seeking entry into the us and facilitating entry; processing and granting immigration-related benefits; patrolling the borders and inspecting individuals at ports-of-entry; deterring and investigating illegal employment and providing information to employers and benefit providers to prevent 
illicit employment or benefit receipt; and disrupting and dismantling organizations engaging in document and benefit fraud and the smuggling of aliens. In addition, INS apprehends, detains, and removes aliens present in the Us without lawful status and/or those who have violated us criminal laws. As individual aliens do engage in criminal activity and organizations that facilitate illegal immigration are often associated with other criminal activity, INs plays a critical role in enforcing us Criminal laws and co-operating with other federal, state, and local law enforcement agencies in activities such as drug smuggling, terrorism, and other criminal activity.

Table 3.3 Overview of main governmental organizations handling immigration issues

\begin{tabular}{|l|l}
\hline National government & Main functions \\
\hline Ministry of Justice & $\begin{array}{l}\text { National and international co-ordination of immi- } \\
\text { gration policy } \\
\text { Process of immigration and naturalization applica- } \\
\text { tions; shared responsibilities for enforcement } \\
\text { Housing for asylees }\end{array}$ \\
$\begin{array}{l}\text { (Immigratie and Naturalization Service } \\
\text { asylees (Centraal Orgaan Opvang Asiel- } \\
\text { zoekers (COA)) }\end{array}$ & \\
Ministry of Home Affairs (includes police) & $\begin{array}{l}\text { National co-ordination of integration policy } \\
\text { and return policy } \\
\text { Supervision of foreigners staying in the Netherlands }\end{array}$ \\
Foreigner service (Vreemdelingendienst) & $\begin{array}{l}\text { Development and implementation of employment } \\
\text { and social welfare policy } \\
\text { Education of immigrants }\end{array}$ \\
Ministry of Education & $\begin{array}{l}\text { Country reports (which serves as a basis to decide } \\
\text { whether asylum seekers from specific countries will } \\
\text { be admitted) } \\
\text { Border enforcement }\end{array}$ \\
Ministry of Foreign Affairs & \\
\hline $\begin{array}{l}\text { Ministry of Defense/Royal Marechaussee } \\
\text { (with some involvement of the Ministry of } \\
\text { Finance/Customs) }\end{array}$ & \\
\hline
\end{tabular}

In the Netherlands, the Ministry of Justice - and more precisely the Immigration and Naturalization Service (IND) - bears the main responsibility for the implementation of the country's immigration policy. In doing so, the IND co-operates closely with instances ranging from the police, the Royal Marechaussee, and the customs service to the Central organization for the reception of asylees, the Foreigners service, and the Ministry of Foreign Affairs.

\subsubsection{CATEGORIES OF IMMIGRATION POLICY}

In theory, immigration policy can consist of three different components: 
- A 'shaping' component - where countries attempt to help shape the international environment within which migratory flows can emerge with the aim of modulating immigration flows into that specific country.

- An 'admission' component - in which immigrant flows are controlled at a country's external borders.

- An 'enforcement' component - in which the admission criteria are enforced throughout the country.

In addition to immigration policy, most countries have policies focused on integration of legally admitted immigrants into their societies. These policies are dealt with in more detail in chapter 4 . The purpose of this section is to assess the relative weight given in both countries to these three components (the final two of which will be dealt with separately in subsequent sections of the report).

\section{The shaping component}

The literature on immigration frequently ignores or underplays the potential importance of various 'shaping' policies that can affect current of future migration flows into a country. Many developed countries' external policies have implicit immigration aims, although this link is typically not made explicit.

In the Us, many external policies have immigration 'shaping' goals - mostly implicit, but at times also explicit. The us does not have a systematic policy of preventing people from coming to the Us. Nonetheless, policy makers are conscious that improving conditions in countries, such as Mexico, might deter immigration from these countries in the long-term (20+ years). The State Department also has a special 'Bureau of Population, Refugees, and Migration' with a primary responsibility for formulating policies on population, refugees, and migration, and for administering Us refugee assistance and admissions programs. The Bureau recognizes that the root causes of migration are linked to human rights abuses, economic and political opportunity, family reunification, and, increasingly, to environmental degradation; and argues that us external policies can reduce the push factors of migration (www.state.gov/www/global/prm/CPDFY200o.pdf).

Other examples of such 'shaping' policies include:

- $\quad$ North American Free Trade Agreement (NAFTA) (where the link with immigration was more explicit than in many other examples);

- $\quad$ us financial assistance programs around the world;

- Military policy (including the us military intervention of Haiti);

- Conflict prevention and management strategies;

- Bilateral diplomatic efforts aimed at specific countries - e.g. the us has (or has had) bilateral relations in the migration field with other countries such as Mexico, Haiti, Canada, Ireland, Bosnia, and China. 


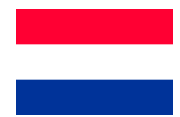

Although Dutch foreign and security policy (e.g. trade and aid policy at both the national and the EU level; the eu's enlargement policy; normal diplomatic activity; military participation in 'Petersburg' tasks; etc.) affects migratory flows, the Dutch external relations apparatus does not appear to have a direct function with respect to immigration policy.

\section{The admission component}

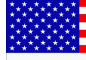

Immigration control commences at the international level as us embassies and consulates abroad play a role in issuing visas to prospective migrants. Beyond this initial step, the us also has agreements with transport companies (ships, airlines) to make certain travelers to the us have the necessary paperwork and visas to enter the country. Just as in countries such as France and Germany, the us levy fines for non-compliance by carriers (Vernez, DRU-757-FF/CC p.16).

At the national level, aliens (any person not a citizen of the us) can be admitted legally to the Us in a variety of ways: e.g. as immigrants, non-immigrants, refugees, and asylees. While some of these statuses confer a right to permanent residency, others are of a temporary nature. Since an alien entering in one category can change status to another, these categories are not fixed. Further details will be discussed in the next section.

The procedure of admission in the Netherlands also has an international and a national level. Immigration control commences at the international level as Dutch embassies and consulates abroad play a large role in issuing authorizations for temporary stay to prospective immigrants. At the national level, aliens can be admitted legally to the Netherlands in a variety of ways: e.g. as immigrants, EU/EEA citizens, and asylees. Further details will be discussed in the next section. 


\section{The enforcement component}

The most important category of us immigration policies is enforcement at the borders, and has clear priority over interior enforcement. Policy outside the borders represents a small and forgotten component of foreign policy with rare exceptions (e.g. Haiti). Usually, foreign policy with respect to immigration is reactive.

Looking at the funding by program (Table 3.3), one notes that programs such as Border Patrol and Detention/Deportation indeed have higher funding levels; in addition, they have experienced greater percentage increases in their budgets (e.g. +854 for Border Patrol between 1993 and 2000).

Border control is the most visible element in enforcement policy. Its main task is to secure the 8,000 miles of land and water boundaries of the us between ports of entry (there are some 250 ports of entry into the Us; in Fiscal Year 1999 (FY 1999), more than 525 million inspections of individuals were conducted at these ports of entry).

There is an element of enforcement within the borders as well. Complimenting the INs' border management efforts, interior resources are concentrated on

- Removing criminal and other illegal aliens;

- Breaking smuggling rings;

- Responding to community reports and complaints about illegal immigration;

- Countering immigration benefit and document fraud;

- Enforcing immigration law among employers (e.g. rules governing the treatment of those who hire undocumented workers)

The budget for the INS in FY 1999 was $\$ 3.9$ billion - a 150\% increase from the

FY 1993 budget ( $\$ 1.5$ billion). The spending breakdowns for FY 1999 was as follows:

\section{Table $3.4 \quad$ Spending breakdown FY 1999 (in billions)}

\begin{tabular}{|l|l|}
\hline Enforcement programs & $\$ 2.500$ \\
Citizenship and other immigrant services & \\
Shared support for both missions/programs & $\$ 0.530$ \\
Total & $\$ 3.906$ \\
\hline
\end{tabular}

Source: 1997 Statistical Yearbook of the INS.

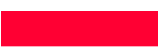

Control of people entering the Schengen area (effective since 1994) is effectuated at the zone's external borders. As a result, the Netherlands's national border control possibilities are restricted to:

- Concentration on entry posts at external borders: sea ports; Schiphol and other airports (including gate checks); 
- $\quad$ 'Mobile oversight on foreigners' (Mobiel Toezicht Vreemdelingen (MTV)) controls: behind and along all borders on international trains and busses, on motorroads, and in seaports;

- Controls in countries of origin: control before granting of visa; boarding checks.

Table 3.5 Spending breakdown FY 2001 (in millions NLG)

\begin{tabular}{|l|r}
\hline Ministry & FY 2001 \\
\hline Justice & 429.2 \\
$\quad$ IND & 2102.0 \\
Asylum seekers care & 237.7 \\
Ama's* & 35.0 \\
Interpreters & 79.0 \\
$\quad$ Foreigner chambers & 102.0 \\
$\quad$ Legal assistance & 164.1 \\
Home Affairs & \\
$\quad$ Police & 25.0 \\
State Council & \\
$\quad$ Appeals & 132.0 \\
Oc\&w & \\
$\quad$ Education asylum seekers & 219.8 \\
Defense & $\mathbf{3 5 2 5 . 8}$ \\
$\quad$ Royal Marechaussee & \\
Total & Asylees under the age of 18 present in the Netherlands without parents \\
\multicolumn{2}{|c|}{ Source: Tweede Kamer, vergaderjaar 2000-2001, 27 400 VI, nr. 10, p. 26. }
\end{tabular}

\subsection{ADMISSION POLICY}

Section 3.2 discusses the admission of regular immigrants, i.e. all legal immigrants with the exception of asylees and refugees. This section focuses on the main principles of admission policy, and the problems related to the implementation of this policy. It also gives some statistics on the admission of regular immigrants. 
Table 3.6 Admission policy

\begin{tabular}{|c|c|c|c|}
\hline Topic & The Netherlands & United States & Remarks \\
\hline Principles & $\begin{array}{l}\text { 'No, unless...': } \\
\text { Family formation and } \\
\text { reunification; } \\
\text { Dutch return migration and } \\
\text { EU immigration; } \\
\text { Asylees/refugees. }\end{array}$ & $\begin{array}{l}\text { 'No, unless...': } \\
\text { Family reunification, } \\
\text { Employment-based } \\
\text { preferences; } \\
\text { 'Diversity' immigrants } \\
\text { Asylees/refugees }\end{array}$ & $\begin{array}{l}\text { Same fundamental princi- } \\
\text { ples, but different weights: } \\
\text { in US, more allowance for } \\
\text { critical labor skills and de- } \\
\text { tailed criteria; in NL more } \\
\text { free movement of people. }\end{array}$ \\
\hline Key problems & $\begin{array}{l}\text { Backlogs in administration; } \\
\text { problems related to exten- } \\
\text { sion of residence permits; } \\
\text { quality of IND-decision- } \\
\text { making }\end{array}$ & $\begin{array}{l}\text { Organization; procedure } \\
\text { (backlog applications); } \\
\text { number of immigrants; } \\
\text { selectivity of immigrants; } \\
\text { critical skills }\end{array}$ & $\begin{array}{l}\text { Similar problems with } \\
\text { respect to the length of the } \\
\text { application procedure. }\end{array}$ \\
\hline Data and trends & $\begin{array}{l}\text { Total of } 122 \mathrm{k} \text { legal immi- } \\
\text { grants in } 1998 \text { (i.e. } 8 \text { per } \\
1000 \text { pop.) } \\
\text { Sizeable emigration (about } \\
50 \% \text { of immigration) } \\
\text { Most immigrants from } \\
\text { developed world } \\
\text { Historically unprecedented } \\
\text { number of immigrants (the } \\
\text { peak in Dutch history was } \\
1998 \text { ). } \\
\text { Illegal immigration thought } \\
\text { to be relatively small }\end{array}$ & $\begin{array}{l}\text { Total of } 660 \mathrm{k} \text { legal im- } \\
\text { migrants in } 1998 \\
\text { (i.e. } 2.5 \text { per } 1000 \text { pop.) } \\
\text { Relatively small emigration } \\
\text { Most immigrants from } \\
\text { Mexico (ca. } 20 \%) ; 33 \% \\
\text { from Asia ( } 5.6 \% \text { China, } \\
5.5 \% \text { India) } \\
\text { Historically high: not } \\
\text { unprecedented in } \\
\text { numbers, but unprece- } \\
\text { dented in its duration. } \\
\text { Illegal immigration thought } \\
\text { to be relatively large }\end{array}$ & $\begin{array}{l}\text { In the Netherlands, immi- } \\
\text { gration and emigration are } \\
\text { relatively higher than in } \\
\text { the US. There are large dif- } \\
\text { ferences in the nations of } \\
\text { origin of immigrants to the } \\
\text { US and to the Netherlands. } \\
\text { The uS probably has a rela- } \\
\text { tively larger influx of illegal } \\
\text { immigrants than the } \\
\text { Netherlands. }\end{array}$ \\
\hline Expenditures & $\begin{array}{l}\text { IND expenditures increased } \\
\text { from } 176 \text { million Dutch } \\
\text { guilders in } 1995 \text { to } \\
533 \text { million Dutch guilders } \\
\text { in } 2000 \text {. }\end{array}$ & $\begin{array}{l}\text { INS expenditures: between } \\
1993 \text { and FY, the INS } \\
\text { budget increased from } \\
\$ 1.5 \text { to } \$ 3.8 \text { billion }\end{array}$ & $\begin{array}{l}\text { Explosive growth in ex- } \\
\text { penditures, limited data on } \\
\text { value for money. }\end{array}$ \\
\hline
\end{tabular}

\subsubsection{PRINCIPLES}

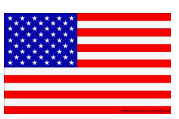

The us implements a restrictive immigration policy, in which prospective immigrants have to satisfy a number of requirements before they can be lawfully admitted to the Us. These requirements vary according to whether a person is seeking permanent or temporary admission to the us.

\section{Permanent admission}

According to us immigration law, immigrants are persons lawfully admitted for permanent residence in the us. Preferential immigration status is extended to individuals with a close family relationship with a us citizen or legal permanent resident, persons with specialized job skills, or individuals qualifying as refugees. 
Immigrants in other categories tend to account for relatively few admissions, the only recent exception occurring between 1989-92 when over 2.6 million former illegal aliens gained permanent resident status through legalizing provisions given by the Immigration and Reform and Control Act (IRCA) of 1986. While IRCA opened the door to many immigrants, it also sought to limit the flow of illegal immigrants. Through employer sanctions, employers would be held responsible should they hire illegal workers.

The Immigration and Nationality Act (INA) of 1990 specified a worldwide level immigration open to certain categories of immigrants. The annual limit is 675,000 depending on admissions in the previous year. The principal categories and their limits (in parentheses) are:

- Family-sponsored preferences (480,000);

- Employment-based preferences (140,000);

- Diversity immigrants $(55,000)$.

The total ceiling and the ceiling on family-sponsored preferences can be broken, because there is no limit on the number of immediate (nuclear family) members that can come in.

In addition to the above categories, other categories of immigrants are admitted, such as refugees and asylees.

Section 203 of the INA prescribes preference classes for allotment of immigrant visas as follows:

\section{Family-Sponsored Preferences}

- First: Unmarried sons and daughters of citizens: 23,400 plus any numbers not required for fourth preference.

- Second: Spouses and children, and unmarried sons and daughters of permanent residents: 114,200, plus the number (if any) by which the worldwide family preference level exceeds 226,00o, and any unused first preference numbers:

- Spouses and children: 77 percent of the overall second preference limitation, of which 75 percent are exempt from the per-country limit;

- Unmarried sons and daughters (21 years of age or older): 23 percent of the overall second preference limitation.

- Third: Married sons and daughters of citizens: 23,400, plus any numbers not required by first and second preferences.

- $\quad$ Fourth: Brothers and sisters of adult citizens: 65,000, plus any numbers not required by first three preferences.

\section{Employment-Based Preferences}

- First (EB-1): Priority Workers: Persons of extraordinary ability in the sciences, arts, education, business, or athletics; outstanding professors and researchers; and certain multinational executives and managers. (28.6\% of the worldwide employment-based preference level, plus any numbers not required for fourth and fifth preferences). 
- Second (EB-2): Professionals holding advanced degrees, and persons of exceptional ability in the sciences, arts, and business: 28.6 percent of the worldwide employment-based preference level, plus any numbers not required by first preference.

- Third (EB-3): Professionals holding baccalaureate degrees, skilled workers with at least two years experience, and other workers whose skills are in short supply in the us: 28.6 percent of the worldwide level, plus any numbers not required by first and second preferences, not more than 10,000 of which to 'Other Workers'.

- Fourth (EB-4): Certain Special Immigrants - certain religious workers, ministers of religion, certain international organization employees and their immediate family members, and qualified, recommended current and former us Government employees: 7.1 percent of the worldwide level.

- Fifth (EB-5): Employment Creation - persons who create employment for at least ten unrelated persons by investing capital in a new commercial enterprise in the us (the minimum capital required is between $\$ 500,000$ and $\$ 1,000,000$, depending on the employment rate in the geographic area): 7.1 percent of the worldwide level, not less than 3,000 of which reserved for investors in a targeted rural or high-unemployment area, and 3,00o set aside for investors in regional centers.

A total of 140,000 employment-based immigrant visas and green cards may be issued each governmental fiscal year by the INs. These immigrant visas are broken down into different categories for each country in the world. Each category has different levels of credentials necessary in order to qualify. Once the available immigrant visas are gone for a particular category and country, no more immigrant visas can be issued for that year. This why there is a backlog for foreign nationals from certain countries (such as India and the People's Republic of China) to obtain their immigrant visas, even though they have fulfilled all the requirements necessary to obtain a green card.

\section{Diversity immigrants}

The diversity immigrant law took effect on 29 November 1990 through the passage of the INA. Article 203 of this Act states that as of October 1, 1994, 55,000 immigrant visas are to be made available annually to individuals of foreign states which the us Attorney General has determined to have had a previous low ratio of immigrants admitted under other sections of the immigration law (e.g. family preference). Diversity immigrants must file an application with the us Department of State. The application period usually runs for a couple of weeks in November-applicants that meet the criteria (having a high school education or two years of recent work experience in a skilled job) can apply from anywhere (even within the us).

Prospective immigrants are identified by random selection (a 'lottery') and a total of 55,000 visas are available annually. Nationals of countries with more than 50,000 numerically limited admissions during the preceding 5 years are excluded from participating in the program. The maximum visa limit per country is 3,850 . The quotas for 
1995 and 2000 were 55,000. The number of requests, however, is greater than the number of visas available, because not everyone selected will be qualified for the visa or will choose to complete the processing. Once 50,000 visas have been issued, the diversity visa program for the year will end.

There is no fee for entering the lottery. People who win must pay a fee for an immigrant visa and a separate visa lottery surcharge. Before the issuance of an immigrant visa, every applicant, regardless of age, must undergo a medical examination. Anyone who is given a visa through the Diversity Lottery Program will be authorized to live and work permanently in the Us. In addition, they are allowed to bring their spouse and any unmarried children (<21 years) to the us.

\section{Temporary admission}

Temporary admittees include visitors to the US, students, people coming to the US to engage in business transactions, and temporary workers. The us government has an 'open door' policy for most non-immigrant classes of admission.

There are specific visas for temporary workers, called $\mathrm{H}-1$ visas. The $\mathrm{H}-1$ visas are a class of non-immigrant visa that may be issued to individuals who seek temporary entry in a specialty occupation as a professional. Examples of $\mathrm{H}-1 \mathrm{~B}$ 'specialty occupations' include accounting, computer analysis, engineering, science, law, financial analysis, or architecture. The petition can be approved with a combination of college or university course work plus three years work experience for each year of university education missing. An $\mathrm{H}-1 \mathrm{~B}$ is approved by the INs for an initial period of up to three years renewable for another three years for a total of six years. Section 106 contains special provisions requiring the INS to grant extensions, in one-year increments, past the six-year maximum, should there be lengthy adjudications.

The Netherlands implements a restrictive immigration policy, in which prospective immigrants have to satisfy a number of requirements before they can be lawfully admitted to the Netherlands. As in the Us, the basic principle behind Dutch immigration policy is 'No, unless....' Foreigners (anybody who does not have Dutch nationality) can only be admitted for legal residence on the basis of (Vreemdelingenwet 2000, Art. 13):

- International legal obligations, such as the:

- Maastricht Treaty on European Union (free movement and residence of people within the EU);

- the Schengen and Dublin agreements (first country of physical entry responsible for asylum request - e.g. in 1999 the Netherlands made 1659 Dublin claims with other European countries; in first 8 months of 2000, 2380, of which 1950 were accepted); 
- European Convention for the Protection of Human Rights and Fundamental Freedoms (including the right to a family life);

- $\quad$ the Geneva Convention and Protocol Relating to Refugees 1951 / 1967

(refugee-specific rights, including non-refoulement);

- Substantial national interest ('if the presence of the foreigner serves a substantial Dutch interest' - e.g. critical labor skills); and

- 'Urgent reasons of a humanitarian nature.'

\section{Permanent admission (>3 months)}

On the basis of the general principles described above, the following categories of people can petition for legal residence:

- Citizens of the European Union (or European Economic Area²) member states;

- $\quad$ Family formation or reunion (including of non-married couples);

- $\quad$ Skilled labor (more in 6os and 70s; now more restricted, but still possible - e.g. in horticulture; or in special cases for scientists, professional top athletes or managers of large companies);

- Study or medical treatment (temporary residence permit);

- Asylum seekers (see special section on asylum seekers);

- Invited refugees (every year, some 500 refugees are taken on basis of agreements with UNHCR);

- Other special smaller groups (imams, seamen, au pairs, adoption or foster children, victims of women smuggling);

- 'Urgent reasons of a humanitarian nature.' Even in cases where none of the above apply, the Dutch Minister of Justice can decide to grant a residence permit.

Most foreigners have to satisfy certain conditions to be granted residence. At first, they must have petitioned for residence from abroad. Secondly, they have to demonstrate having sufficient means of subsistence. And finally, they have to demonstrate that they do not have a criminal past. Different criteria apply for the admission of different categories of immigrants.

Regular aliens: Aliens planning to stay in the Netherlands for more than three months require a residence permit (Vergunning Tot Verblijf (VTV)). The grounds on which residence permits are issued to applicants can be distinguished in two categories:

1 Temporary purpose for residence: entering the Netherlands to study or participate in a training program, to work as an au pair, to participate in exchange programs of over three months, or to visit family for longer than three months;

2 Non-temporary purpose for residence: entering the Netherlands in order to live with a partner or spouse or to work.

To qualify for a residence permit, people first need to apply for an authorization for temporary stay (Machtiging tot Voorlopig Verblijf (MVV)). Applicants for the MVV must apply in person at the Dutch embassy or consulate in their country of 
residence, or may have the application procedure initiated in the Netherlands via a sponsor, e.g. the future employer of the applicant. It is then checked whether the person submitting the request meets the criteria for staying in the Netherlands. To obtain the Mvv, the person needs to have a valid passport and needs to pay a fee. The MvV entitles the person to travel to the Netherlands (including via through other Schengen-countries). After arriving in the Netherlands, applicants must apply for a residence permit (VTV) - within three working days - from the Aliens Police (Vreemdelingendienst) in the Netherlands. To process the request, a fee has to be paid. In principle, a VTV is valid for one year. However, under some conditions it may be extended (www.immigratiedienst.nl).

EU/EEA citizens: EU/EEA citizens are subject to different rules than other foreigners. EU/EEA citizens may stay in the Netherlands in accordance with the EC Convention, and if the purpose of their stay is not in accordance with the Ec Convention, they may stay if they meet the criteria of the Aliens Act. The EC Convention distinguishes several lawful categories of immigrants:

a working in the Netherlands as an employee;

b working in the Netherlands as a self-employed person;

c economically inactive (applies only for people who can show that they have independent means of subsistence);

d studying (applies only for higher and vocational education);

e staying with relatives.

All categories of immigrants need to have a valid passport and health insurance covering all risks in the Netherlands. If an EU/EEA citizen wants to stay in the Netherlands for another reason than the ones described above, e.g. stay with a Dutch partner, or as an au pair with a Dutch host family, they are subject to the regular aliens policy.

Asylees/refugees: The specific procedure applying to admission of asylees and refugees is described in section $3 \cdot 3$.

\section{Temporary admission (<3 months)}

Different criteria apply to regular aliens and EU/EEA citizens who want to stay in the Netherlands temporarily (less than three months).

Regular aliens: In principle, aliens wishing to stay in the Netherlands for a short period (as tourists, to conduct business or visit family) need a visitor's visa. This visa requirement is waived for visitors of certain nationalities, mostly Western European or North American. The maximum validity for a visitor's visa is three months.

EU/EEA citizens: Any citizen of the EU or EEA may in any event stay in the Netherlands for three months. A valid travel document and sufficient money to be able to live are required. 


\subsubsection{KEY ISSUES}

This subsection discusses the key issues regarding admission policy considered in the legislature, raised by experts, and discussed/talked about in media. It should be noted that many have been objects of legislation.

\section{INS organization}

INS is seeking to respond to several outside and Congressional attempts to break the agency into two parts: one part focused on processing of immigration and naturalization applications, and one part focused on enforcement of immigration laws. This pressure for reorganization of INS results from 2 major problems, namely:

a ineffective enforcement, and

b slow and unresponsive processing of applications, mostly for naturalization.

\section{Administrative--backlog applications}

A different kind of policy problem is how to deal with the backlog of immigrant applications for naturalization. At the end of fiscal year 1999, there were just under two and a half million applications pending. While there are about 2.5 million people waiting their turn to come to the Us, they are waiting because of the ceiling. This is not viewed as a major issue to be corrected.

The processing fees have been raised so that more staff can be hired. This has started to gradually lower the amount of backlog applications. Another measure taken has been to improve the fingerprinting program. The INs has standardized its methods of making fingerprints, thereby reducing the rejection rates and turnaround times. Specifically, the INs has introduced Application Support Centers (ASCs), collocated fingerprint offices and mobile routes while establishing fingerprint locations at convenient locations that provide high quality prints. Before ASC, the Federal Bureau of Investigations rejected up to 40 percent of the fingerprints submitted by the INs for background checks. In FY 2000, the rejection rate has dropped to 5 percent and turnaround time is under 21 days. In addition, the INS has streamlined the process further by shifting preliminary review and processing to the Service Centers to allow officers more time to adjudicate cases. Finally, the INs has developed goals, plans, and accountability standards required to reduce the backlog of both naturalization cases and adjustment of status cases.

\section{Absolute number of immigrants}

Immigration is currently at its highest absolute levels with some 1.1 million immigrants annually (including refugees and asylees), some 400,00o higher than the Great Migration period of the 1900-1920s (although it represents a smaller per- 
cent of total population: 0.4 percent compared to 0.7 percent in the 1900-20s). This issue will gain more attention should the economy take a downturn.

\section{Selectivity of immigrants}

With record numbers of immigrants coming to the us, a question of selectivity has gained momentum - especially in the area of educational attainment. For example, in California, McCarthy et al. (1997) find that 'the magnitude of current flows - and the flows' disproportionate share of poorly educated immigrants has increased the costs of immigration to the state's public sector and to some nativeborn workers.' This led to an increasingly intense discussion about criteria for admission of immigrants.

\section{Citizen children}

Since anybody born in the US automatically is a US citizen, children born in the US to illegal parents present another challenge. There are an estimated 500,000 such children currently living in the us. Citizen children pose a dilemma to the INS as the parents (illegal immigrants) could be deported, but it is unclear what would happen to the children in that case.

\section{Labor shortages}

Another issue area is how to fill critical labor shortages. Initial measures have been taken to address this problem by expanding the number of visas available to highskilled workers, especially in the technology area. The technology industry has successfully lobbied for the increase in H1-B on the grounds that its growth would be impaired otherwise. According to a Georgetown University study of $\mathrm{H}-1 \mathrm{~B}$ workers, 'if not all, at least the majority' of H1-B workers intend to stay permanently in the Us. However, the H1-visas are only good for six years. People who want to stay in the us permanently need to get a new status.

\section{Backlogs in administration of residence permits}

There is a backlog in administration of applications for regular migration to the Netherlands. The main problems concern VTV-applications/-appeals; the backlogs with respect to other types of applications (MVV-applications/-appeals, visaapplications/-appeals) are considered to be acceptable. The backlogs in VTVapplications/-appeals are mainly caused by the large number of "white illegals ' 3 applying for a VTV. In addition, there is a backlog in court cases with respect to regular migration (Tweede Kamer, 27400 VI, No. 10: 11).

\section{Problems related to extension of residence permits}

Generally, the requirement to obtain an authorization for temporary stay (MVV), as introduced in 1998, is considered to be effective. An increasing number of people 
is applying for an MVV from their home country (instead of in filing an application in the Netherlands). However, difficulties are identified with respect to:

- People residing in the Netherlands who want to extend their stay in the Netherlands: Often these people do not request extension of their permit in time. One of the main reasons for this is that these people are, in principle, required to request extension of their permit from their home country. This is not very practical, especially because the person might lose his or her job by leaving the country for some time, and therefore lose his or her right to a residence permit.

- People residing in the Netherlands who want to change the purpose of their stay in the Netherlands, e.g. foreign students who want to change studies. In principle, these people need to return to their home country to request extension of their residence permit. This is considered to be somewhat unreasonable.

\section{Quality of IND decision-making}

Some people have doubts about the quality of the decisions made by the Dutch IND because 30 percent of the IND-decisions were reversed by the courts. This holds for decisions with respect to both regular migration and asylum. In addition, the number of appeals on IND-decisions has increased in recent years (Tweede Kamer, 27400 VI, No. 10: 75-79).

\subsubsection{STATISTICS}

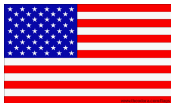

Table 3.7 Immigrants admitted from top ten countries of birth (FY 1997)

\begin{tabular}{|l|rr}
\hline Country & Number & Percentage \\
\hline Mexico & 146865 & $18.4 \%$ \\
Philippines & 49117 & $6.2 \%$ \\
China & 41147 & $5.2 \%$ \\
Vietnam & 38519 & $4.8 \%$ \\
India & 38071 & $4.8 \%$ \\
Cuba & 33587 & $4.2 \%$ \\
Dominican Republic & 27053 & $3.4 \%$ \\
El Salvador & 17969 & $2.3 \%$ \\
Jamaica & 17840 & $2.2 \%$ \\
Russia & 16632 & $2.1 \%$ \\
Total & $\mathbf{7 9 8 3 7 8}$ & $\mathbf{1 0 0 \%}$ \\
\hline
\end{tabular}

Source: 1997 Statistical Yearbook of the INS 
Table 3.8 Immigrants admitted by major category of admission (FY 1997)

\begin{tabular}{|l|r}
\hline Categories related to numerical limits & $\mathbf{6 7 5 , 8 1 6}$ \\
- Family-sponsored immigrants & 535,771 \\
- Legalization of dependents & 64 \\
- Employment-based preferences & 90,607 \\
- Priority workers & 21,810 \\
- Professionals with advanced degree or of & 17,059 \\
exceptional ability & \\
- Chinese Student Protection Act & 142 \\
- Needed unskilled workers & 8,702 \\
- Other skilled workers, professionals & 33,752 \\
- Special immigrants & 7,781 \\
- Investors & 1,361 \\
- Diversity programs & 49,374 \\
Other Categories & $\mathbf{1 2 2 , 5 6 2}$ \\
- Ameriasians & 738 \\
- Parolees, Soviet and Indochinese & 1,844 \\
- Refugee adjustments & 102,052 \\
- Asylee adjustments & 10,106 \\
- Suspension of deportation & 4,628 \\
- Total, IRCA legalization & 2,548 \\
- Other & 646 \\
All categories & $\mathbf{7 9 8 , 3 7 8}$ \\
\hline
\end{tabular}

Source: 1997 Statistical Yearbook of the INS

Table 3.9 Applications for immigration (FY 1998 and FY 1999)

\begin{tabular}{|l|r|}
\hline Initial receipts & $4,534,559$ \\
Approved & $3,574,489$ \\
Denied & 314,836 \\
Pending & $2,488,205$ \\
\hline \multicolumn{2}{|c|}{ Source: INS website }
\end{tabular}

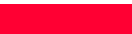

Table 3.10 Immigrants admitted from different regions (1998)

\begin{tabular}{|l|rr}
\hline $\begin{array}{l}\text { Region of } \\
\text { origin }\end{array}$ & Number of immigrants & \multicolumn{2}{c}{$\begin{array}{l}\text { \% of immigrants who do not } \\
\text { have Dutch citizenship }\end{array}$} \\
\hline Europe & 51800 & $67.1 \%$ \\
America & 26300 & $39.7 \%$ \\
Asia & 25400 & $85 \%$ \\
Africa & 16500 & $82.9 \%$ \\
Oceania & 2000 & $41 \%$ \\
Total & 122400 & $66,7 \%$ \\
\hline
\end{tabular}

* the remaining groups are Dutch citizens returning to the Netherlands Source: CBS (2000: 64)

Table 3.11 Influx of regular immigrants (1999)

\begin{tabular}{|l|l|}
\hline MVV & 36968 \\
\hline VTV & 20222 \\
\hline Visas & 32306 \\
\hline
\end{tabular}

Source: www.minjust.nl 
Table 3.12 Status of the applications for regular immigration (31-8-2000)

\begin{tabular}{|l|rrrrrr}
\hline & VTV & MVV & $\begin{array}{r}\text { VTV- } \\
\text { appeals }\end{array}$ & $\begin{array}{r}\text { MvV- } \\
\text { appeals }\end{array}$ & Visa & $\begin{array}{r}\text { Visa- } \\
\text { appeals }\end{array}$ \\
\hline 0-3 months & 1628 & 2837 & 4294 & 869 & 3216 & 1054 \\
3-6 months & 1146 & 930 & 3124 & 912 & 648 & 957 \\
6 months - 1 year & 2111 & 1059 & 3069 & 995 & 96 & 1530 \\
> 1 year & 2211 & 759 & 7477 & 1539 & 145 & 636 \\
Total & $\mathbf{7 0 9 6}$ & $\mathbf{5 1 3 4}$ & $\mathbf{1 7 9 6 4}$ & $\mathbf{4 3 1 5}$ & $\mathbf{4 1 0 5}$ & $\mathbf{4 1 7 7}$ \\
\hline
\end{tabular}

Source: Tweede Kamer, 27400 VI, No. 10, p. 11.

\subsection{ASYLEES AND REFUGEES}

Section 3.3 pays special attention to one specific class of immigrants, namely asylees and refugees. This class needs special attention, because the admission policy for asylees and refugees is significantly different from the admission policy for regular immigrants. This section focuses on the main principles of admission for asylees and refugees and offers some key statistics on this class of immigrants.

Table 3.13 Asylees and refugees

\begin{tabular}{|c|c|c|c|}
\hline Topics & The Netherlands & United States & Remarks \\
\hline Principles & $\begin{array}{l}\text { Governed by international } \\
\text { agreements }\end{array}$ & $\begin{array}{l}\text { Party to the } 1967 \text { Protocol } \\
\text { relating to the Status of } \\
\text { Refugees and has enacted } \\
\text { relevant legislation governing } \\
\text { the protection of refugees }\end{array}$ & \\
\hline Criteria & $\begin{array}{l}\text { Dependent upon country } \\
\text { of origin }\end{array}$ & $\begin{array}{l}\text { Dependent upon country of } \\
\text { origin }\end{array}$ & \\
\hline Issues & $\begin{array}{l}\text { Unpredictability of } \\
\text { number of asylees, } \\
\text { determination of } \\
\text { admission criteria }\end{array}$ & 'Expedited procedure' & \\
\hline Data & $\begin{array}{l}45,217 \text { claims submitted } \\
\text { in } 1998 ; 15,000 \text { approved } \\
\text { ( } 0.1 \text { per } 1000 \text { pop); } \\
31.6 \text { approval rate; } \\
131,800 \text { resident refu- } \\
\text { gees ( } 8 \text { per } 1000 \text { pop) } \\
\text { (www.unhcr.ch) }\end{array}$ & $\begin{array}{l}42,530 \text { asylum applications in } \\
1999 \text { ( } 50 \% \text { decline from } \\
97-98) ; \text { and } 73,000 \text { refugee } \\
\text { applications. Asylum appli- } \\
\text { cations: } 13510 \text { approved; } \\
342,095 \text { pending; } 20.8 \% \text { ap- } \\
\text { proval rate. } 524,000 \text { resident } \\
\text { refugees (www.unhcr.ch) }\end{array}$ & $\begin{array}{l}\text { NL accepts proportionally } \\
\text { many more refugees; } \\
\text { also houses more than } \\
4 \text { times (proportionally) } \\
\text { as many }\end{array}$ \\
\hline
\end{tabular}

\subsubsection{PRINCIPLES}

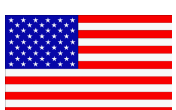

The us offers asylum and refugee protection based on a belief in human rights and in ending or preventing the persecution of individuals. Asylum and refugee pro- 
tection are granted by federal law to qualified applicants who are unable or unwilling to return to their country of nationality because of persecution or a wellfounded fear of persecution. Those individuals with no nationality must generally be outside their country of last habitual residence to qualify as refugees. Claims of persecution must be based on at least one of five internationally recognized grounds: race, religion, ethnicity, membership in a particular social group, or political opinion. Once granted asylum, people are allowed to live and work in the us.

Asylum status and refugee status are closely related. They differ only in the place where a person asks for the status. Asylum is asked for in the us; refugee status is asked for outside of the us. Each fiscal year, the President - after consultation with Congress - determines the number of refugees in need of resettlement who are of special humanitarian concern to the us. Given this figure, the President establishes the authorized number of admissions for the fiscal year. During the year, changes in the need for resettlement may require revisions in the overall limit of refugee admissions or reallocation among areas of the world.

Eligibility for refugee status is decided on a case-by-case basis. INs officers conduct personal interviews of all applicants. Those who are found to be eligible for refugee status and their immediate family members then have medical examinations, attend cultural orientation sessions, and prepare for departure for the Us. Each refugee case is assigned to an American private voluntary agency that - working under co-operative agreement with the Department of State - provides sponsorship and initial resettlement assistance, including housing, food, clothing, and additional cultural and community orientation. Transportation arrangements to the us are usually made through the International Organization for Migration (even though refugees are expected to repay the cost of their transportation). At a Us port of entry, the INS admits the refugee officially and authorizes employment.

The Illegal Immigration Reform and Immigrant Responsibility Act of 1996 provided that some actions taken under coercive population control programs constitute persecution on account of political opinion. A maximum of 1,000 aliens per fiscal year may be granted asylum or admitted as a refugee under this provision.

In addition to asylum and refugee protection, withholding of removal is available to refugees in the us who can demonstrate the likelihood that their lives or freedom would be threatened if they were returned to the country in question. Withholding of removal is in some ways similar to asylum, but is governed by a higher standard, requiring applicants to establish that it is more likely than not that they would be persecuted. Unlike asylum, however, once this standard is met, there is no discretion to deny withholding and the applicant may not be returned to the country. 
It is not easy to receive a residence permit in the Netherlands, but the Dutch government does try to be hospitable to refugees. The Netherlands perceives itself as being a small, heavily populated country, with many housing and other problems. This is why there are strict rules for aliens who want to come and live permanently in the Netherlands. Asylum seekers will be recognized as refugees if there are clear reasons for them to be afraid of persecution in their own countries.

Asylum-seekers are aliens who apply for asylum at the Dutch border. They thereby request protection from persecution on the grounds of their political conviction, faith, race, nationality or belonging to a particular social group in their country of origin. There are different categories of permits for asylum-seekers.

An asylum-seeker whose application is accepted is admitted as a refugee and receives the so-called 'A'-status under Section 10 of the Aliens Act, which is valid for an indefinite period.

Asylum-seekers who are not eligible for an A-status, but who cannot be sent back on urgent humanitarian grounds, may be granted a Permit for Residence (VTV) without restrictions, also known as a Permit for Residence on Humanitarian Grounds (VTV-humanitair). A holder of this permit is also permitted to work.

A temporary residence permit (VVTV) is an exceptional residence permit given to asylum-seekers who cannot be sent back because the situation in the country of origin is very bad. This permit is designed for people fleeing from a war, who can be sent back when the situation improves. If the situation does not improve, the asylum-seeker can be given a VTV after three years. VVTV holders must gradually integrate into Dutch society. In the first year, they must follow orientation and language courses and are allowed to work on a part-time basis. In the second year, they are also allowed to enter professional training. Third-year vVTV holders may work without restrictions. A work permit is not required.

\subsubsection{CRITERIA}

To be admitted to the us as a refugee, each applicant must meet the following criteria:

- Be a refugee as set forth in the Refugee Act of 1980;

- Be among the types of refugees determined to be of special humanitarian concern to the Us;

- Be admissible under the Immigration and Nationality Act;

- Not be firmly resettled in any foreign country. 
According to the State Department, the us Refugee Admissions Program Eligibility for Refugee Processing Priorities covered the following nations in FY 1999: Angola, Bosnia, Burma, Burundi, Cameroon, Chad, Congo (Brazzaville), Congo (DROC), Cuba, Djibouti, Eritreans, Ethiopia, Former Soviet Union, Guinea Bissau, Iran, Iraq, Liberia, Nigeria, Rwanda, Sierra Leone, Somalia, Sudan, Togo, Uganda, and Vietnam.

It should be noted that the UNHCR or Us Embassies may refer members of any nationality group - not only those above - for consideration of admission to the US under Priority $1(\mathrm{P}-1)$. The exception to this is the processing of North Koreans, Libyans, and Palestinians, which requires prior consultation with the Department of State and INs headquarters.

The admission ceiling of 78,000 for 1997 was established and later allocated along geographic regions as follows:

Table 3.14 Admission ceiling (FY 1997)

\begin{tabular}{|l|r}
\hline Africa & 7,000 \\
East Asia & 10,000 \\
Eastern Europe/ Soviet Union (former) & 52,500 \\
Latin America/Caribbean & 4,000 \\
Near East/South Asia & 4,500 \\
Total & $\mathbf{7 8 , 0 0 0}$ \\
\hline
\end{tabular}
on the political, economic, etc. status of most countries in the world. Based on these lists, it is decided whether people from a specific country or ethnicity qualify to enter the Netherlands as an asylee or refugee. 


\subsubsection{STATISTICS}

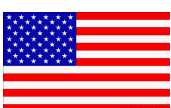

Table 3.15 Refugee status applications filed and approved, and refugees admitted: top ten countries (FY 1997)

\begin{tabular}{|c|c|c|c|}
\hline Nationality & $\begin{array}{r}\text { Applications filed } \\
\text { (number) }\end{array}$ & $\begin{array}{r}\text { Applications } \\
\text { approved (number }\end{array}$ & $\begin{array}{r}\text { Refugee arrivals } \\
\text { (number) }\end{array}$ \\
\hline Yugoslavia & 39,561 & 28,730 & 21,360 \\
\hline Bosnia-Herze. & 38,381 & 27,840 & 21,357 \\
\hline Soviet Union, former & 35,329 & 27,623 & 27,072 \\
\hline Vietnam & 19,552 & 6,522 & 6,660 \\
\hline Cuba & 9,102 & 1,860 & 2,911 \\
\hline Somalia & 6,510 & 5,599 & 4,974 \\
\hline Iraq & 4,573 & 3,289 & 2,679 \\
\hline Congo, Dem.Rep. & 2,664 & 651 & 45 \\
\hline Iran & 2,244 & 1,234 & 1,305 \\
\hline Liberia & 1,620 & 893 & 231 \\
\hline Total & 122,741 & 77,600 & 69,276 \\
\hline
\end{tabular}

Source: 1997 Statistical Yearbook of the INS.

Table 3.16 Requests for asylum: top ten countries (1998)

\begin{tabular}{|l|r}
\hline Nation of origin & Number \\
\hline Iraq & 8300 \\
Afghanistan & 7117 \\
Yugoslavia & 4289 \\
Bosnia-Herzegovina & 3769 \\
Somalia & 2775 \\
Sudan & 1875 \\
Iran & 1679 \\
Azerbaijan & 1268 \\
Turkey & 1222 \\
Sri Lanka & 1049 \\
Total top-10 countries & $\mathbf{3 3 3 4 4}$ \\
Other & 11873 \\
Total & $\mathbf{4 5 2 1 7}$ \\
\hline \multicolumn{2}{c}{ Source: www.minjust.nl }
\end{tabular}

Table 3.17 Decisions with respect to requests for asylum (1998)

\begin{tabular}{|l|r}
\hline Total number of requests & 45217 \\
A-status & 2356 \\
VTV-status & 3591 \\
VVTV-status & 9152 \\
Rejected & 28173 \\
\hline \multicolumn{2}{|c}{ Source: www.minjust.nl }
\end{tabular}

\subsection{ILLEGAL IMMIGRATION}

Section 3.4 focuses on immigrants who have no lawful right to stay in the country to which they have migrated. This class of immigrants poses specific challenges to 
the receiving country, and therefore deserves specific attention. The table below describes the key similarities and differences between the Us and the Netherlands. The remainder of this section provides further detail on the us and Dutch policies and problems.

Table 3.18 Illegal immigration

\begin{tabular}{|l|lll}
\hline Topics & Netherlands & United States & Remarks \\
\hline Principles & $\begin{array}{l}\text { Illegal immigrants have } \\
\text { no rights to stay in the } \\
\text { Netherlands. Certain } \\
\text { policies still implemented } \\
\text { to assist them. }\end{array}$ & $\begin{array}{l}\text { Illegal immigrants have no } \\
\text { rights to stay in the US. } \\
\text { Various states still provide } \\
\text { certain public benefits. }\end{array}$ & \\
Key issues & $\begin{array}{lll}\text { Limited knowledge on } \\
\text { size of illegal immigra- } \\
\text { tion; alien smuggling; } \\
\text { 'white' illegals; removal } \\
\text { of criminal illegals. }\end{array}$ & $\begin{array}{l}\text { High number of illegals; } \\
\text { detection problems; lack of } \\
\text { co-ordination between Ins } \\
\text { and state and local enforce- } \\
\text { ment agencies; lack of } \\
\text { employer enforcement. }\end{array}$ & $\begin{array}{l}\text { The issue of illegal immi- } \\
\text { than in the Netherlands. }\end{array}$ \\
& $\begin{array}{ll}\text { Little is known. } \\
\text { Statistics }\end{array}$ & $\begin{array}{l}\text { Fairly sophisticated counting } \\
\text { methodology. }\end{array}$ & $\begin{array}{l}\text { Need for better account- } \\
\text { ing of illegal immigration }\end{array}$ \\
\end{tabular}

An illegal immigrant does not have a lawful right to stay in the Us. The main categories of illegal immigrants are 'immigrant overstays' and border crossers (more on this later in this section).

With respect to enforcement, the INS has several options in removing an alien from the us. Traditionally, these options have included deportation, voluntary departure, and exclusion. The Illegal Immigration Reform and Immigration Responsibility Act (IIRIRA) made major revisions to these procedures. Deportation and exclusion proceedings have been consolidated as removal proceedings. The most significant change was the new authority for expedited removals. Most removal proceedings are conducted before an immigration judge and lead to either removal, adjustment to a legal status, or termination of proceedings. Besides removal, the penalties associated with formal removal include the possibility of fines, imprisonment for up to 10 years, and a bar to future legal entry for up to 20 years. It seems to be rare to get such harsh penalties (more likely to happen if you have a criminal history). In some cases, aliens may be offered a voluntary departure (common for non-criminals apprehended by the Border Patrol). They agree that their entry was not legal, waive rights to a hearing, remain in custody, and are removed under supervision. 
An illegal immigrant does not have a lawful right to stay in the Netherlands. Important categories of illegal immigrants are overstays and border crossers. In addition, it is suspected that some of the asylum seekers for whom IND took a negative decision on their asylum request stay in the Netherlands illegally.

Illegal immigrants who have been working in the Netherlands for six years in a row were eligible for a residence permit until 1 January 1998. These people are called 'white' illegals (witte illegalen). 7938 people have requested a residence permit based on this regulation. Thus far, approximately 2200 people received a residence permit.

\subsubsection{KEY ISSUES}

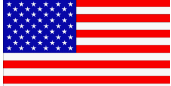

\section{High number of illegal immigrants}

Enforcement policies appear not to have decreased the number of illegal immigrants entering the country. While some regions seem to have experienced a decrease in the number of illegal entrants, others have seen an increase. In some regions the Border Patrol apprehensions decreased by roughly 45 percent in 1994-98, whereas in other regions it rose 88 percent in the same period of time. According to the INs, there has been no drop in apprehensions along the entire California-Mexico border in 1994-98. (Goldsborough 2000: 95). To address this, the 'enforcement' portion of the budget has been increased.

\section{Detection problems}

The main issues in this field are the ease with which fake documents can be obtained and the low level of resources spent on 'interior' enforcement. There are a variety of ways available to 'beat' the system. For example, there is a difficulty pinning down people who have overstayed their visas (effectively becoming illegal aliens) and those who decide to enter the country through the porous/northern parts of the country.

\section{Interdiction}

Aliens are apprehended through three Ins Programs: Border Patrol, Investigations, and Inspections. The largest program is the Border Patrol which in 1997 apprehended 1,412,953 individuals from a total of 1,536,520 (all three programs).

The investigations program focuses on the enforcement of immigration laws within the interior of the Us. The immigration officers involved in investigations often work in multi-agency teams targeted against violent crime, document fraud, narcotic trafficking, and various forms of organized crime. They also work to identify 
aliens who are in prison and deportable as a result of their criminal convictions (these can be removed under the Institutional Removal Program).

Inspections refer to the work/employees at ports of entry who interact with individuals seeking admission to the Us. Inspectors look for fraudulent documents, previous overstays, question applicants under oath, and can search (without a warrant) the applicant and his or her belongings.

\section{Detection strategy}

The detection strategy specifically calls for 'prevention through deterrence,' that is, elevating the risk of apprehension to a level so high that prospective illegal entrants consider it futile to attempt to enter the us illegally. The current strategy focuses resources in phases to the areas of greatest illegal activity, currently certain targeted entry corridors of the Southwest border.

At land border ports, the INS uses a Secure Electronic Network for Travelers Rapid Inspection (SENTRI) system that allows inspectors to use advanced technology to rapidly screen low-risk, frequent travelers. Some three SENTRI lanes are currently operational in the Southern border. In the Northern border, Dedicated Commuter Lanes are used to facilitate entry while freeing up resources to go after illegal entrants.

At international airports, inspection officials use the Advanced Passenger Information System (APIS). Through APIS, the INS obtains biographical passenger information in advance of passengers arriving at selected us ports of entry. According to the INS, over 66 percent of all passengers have been inspected using APIS through June of FY 2000. Sixty-seven carriers are currently signatories to the APIS memorandum of Understanding.

At a deeper level, Border Patrol uses an Integrated Surveillance Intelligence System (ISIS). The ISIS system with night and day surveillance cameras - used in combination with ground sensors - is linked to central controller centers so that Border Patrol agents can be dispatched with strategic information about potential targets. Since 1993, the INs has added some 233 night scopes, 7,299 ground sensors, 82 miles of fencing, 22 miles of border lighting, and added/improved over 1,500 miles of roads (from The Budget for FY 2001: 115). Agents patrol the border in vehicles, boats, aircraft, and afoot. In some areas, the Border Patrol even employs horses, all-terrain motorcycles, bicycles, and snowmobiles.

\section{Institutional issues}

The main issue is the lack of co-ordination between INS and state and local enforcement agencies. State and local enforcement agencies are under no obligation to turn over illegal aliens to the INS, and some states and local areas even have explicit policies against it. The only exception is made for illegal aliens convicted of 
criminal activities who are subject to deportation upon completion of their sentence.

In August 1998, the Attorney General and the Secretary of the Treasury (Department of Treasury) created the Border Co-ordination Initiative (BCI). The objective of the $\mathrm{BCI}$ is to establish a 'comprehensive effort by Federal agencies to create seamless immigration and narcotics enforcement through facilitation processes at and between border ports of entry' (Meissner Testimony before Congress, March 2000). Initially involving the INS and the us Customs Service, it is intended to eventually involve other Federal agencies including the Coast Guard (Department of Treasury), the Department of Agriculture, the Federal Bureau of Investigation (Department of Justice), and the Drug Enforcement Administration (Department of Treasury).

Co-operation with federal, state and local law enforcement agencies is to be enhanced with the deployment of Quick Response Teams (ORTs are new as of FY 1999). ORTs will be deployed to states that are experiencing illegal immigration problems in areas that had not previously been affected. Ideally, QRT agents are to work closely with state and local law enforcement to determine the status of apprehended individuals and remove those determined to be removable. As of 3 January 1999, 188 of the 200 ORTs had been selected with 166 having entered duty at their respective locations (Meissner Testimony before Congress, March 2000).

\section{Lack of employer enforcement}

INS is not aggressively using its employer sanctions power to enforce immigration law. The employer sanctions established under IRCA have not been successful, partly because of lax enforcement due to employer pressures. Without a workers' identification system (which Congress would not include), it is difficult to distinguish between legal and illegal workers. The situation has not improved through the increasing prominence of fake green cards and social security cards.

For example, a major fraud case conducted in FY 1999 resulted in the seizure of 2.1 million false green cards, social security cards, and California state identification cards (INS website).

Through its worksite enforcement operations, INS aims to build relationships with employers, openly conduct audits and surveys, and work with employers after unauthorized workers are removed to ensure continued compliance with immigration laws. Criminal investigations are to focus on employers who engage in the most blatant violations of immigration laws and human rights.

\section{Detention and removal}

The INS uses the Justice Prisoner and Alien Transportation System (JPATs) to move aliens to available detention spaces and remove them from the Us. Established in 1995 by the us Marshals Service and the INS, JPATS represents an air transportation system to transfer or repatriate federal prisoners and detainees. In FY 1999, the INS 
used 60,000 air movements to relocate, remove, and repatriate aliens. For 2001, the INS is projecting a need of 85,000 air movements. (Meissner Testimony before Congress, March 2000). The time it takes on average before people are 'removed' depends on the type of removal. Faster removals are voluntary departures and expedited removals. Cases that go before an immigration judge tend to take longer.

The removal of criminal and other deportable aliens is the first priority of INS' comprehensive Interior Enforcement Strategy, and serves a sort of performance measure for the strategy. Many of these removals (19,798 out of 62,838 in FY 1999) come through the Institutional Removal Program (IRP). The IRP involves identifying, processing, and obtaining a decision on deportable inmates before they are released from Federal, state, and local institutions. In addition, the INs also obtains orders and removes a couple of thousand (4,326 in FY 99) within one day of release from institutions.

\section{Limited knowledge on size of illegal immigration}

It is not known how many illegal immigrants are residing in the Netherlands and how many new illegals enter the Netherlands each year. However, some estimates are available for specific groups of illegals. It is estimated that 1200 illegals in Amsterdam and 500 in Rotterdam are involved in criminal activities. The Netherlands Economic Institute estimated that illegal labor is less than 0.5 percent of the total employment (mainly confection industry, agriculture, and the cleaning industry).

\section{Alien smuggle}

Unauthorized migrants rely more and more on the existence of smugglers.

Smugglers now work in networks and avoid government controls with the help of sophisticated techniques. Smuggling of aliens has become an industry that impedes control over unauthorized entry, leads to exploitation of migrants and endangers their lives and safety. The Dutch government created a specific taskforce to study the issue of alien smuggling.

\section{'White' illegals}

With the introduction of the Koppelingswet 1998 (which links the accessibility of certain provisions, such as a housing permit, to having a legal status), it became more difficult to stay in the Netherlands illegally. An important consequence of this is that illegals who have just arrived in the Netherlands have become more dependent on either the support of people from their home country or informal survival strategies (for housing and labor). The current illegals policy has proved successful in closing the formal labor market for illegals and excluding illegals from social welfare. The fact that more illegals become dependent upon the sup- 
port of people from their own home country leads to a situation in which these people are not able to provide support to all illegals because of limited resources. On the one hand, this slows down the influx of illegal immigrants, but on the other hand this might lead to an increased marginalization. It is feared that a new group of 'white' illegals will come into existence, as an effective enforcement policy is lacking.

\section{Removal of illegals}

There has been discussion in Dutch parliament about the length of the removal procedures. It is generally thought that it takes too long before illegals are removed. This holds for the removal of illegals in general, and for the removal of illegals committing crimes in particular. Recently, the strengthening of removal policies has been discussed in parliament. It has been suggested that the supervision on illegal labor needs to be intensified, that people who refuse to leave the Netherlands can be put in prison and have no right to legal aid, and that the removal of criminal illegals needs to be arranged during their detention.

\subsubsection{STATISTICS}

An estimated 5.0 million undocumented immigrants were residing in the us in October 1996. The population is estimated to be growing by about 275,000 each year, which is about 25,000 lower than the annual level of growth projected by the INS in 1994.

Table 3.19 Estimates for undocumented immigrants

\begin{tabular}{|l|r}
\hline & $\begin{array}{r}\text { Number of undocumented } \\
\text { immigrants }\end{array}$ \\
\hline California & $2,000,000$ \\
Texas & 700,000 \\
New York & 540,000 \\
Florida & 350,000 \\
Illinois & 290,000 \\
New Jersey & 135,000 \\
Arizona & 115,000 \\
\hline \multicolumn{2}{|c}{ Note: These figures account for 83\% of the total estimated population in October 1996.} \\
\hline \multicolumn{2}{|c}{ Source: INS website. }
\end{tabular}

The estimates were constructed by combining detailed statistics, by year of entry, for each component of change that contributes to the undocumented immigrant population residing in the us. For people of most nationalities, the typical way of entering the undocumented population in the us is to arrive as a non-immigrant and stay beyond the specified period of admission. This segment of the population, referred to as 'non-immigrant overstays', constitutes roughly 40 percent of the undocumented immigrant population in the us. The rest of the population, more 
widely publicized, enter across land borders, usually between official ports of entry. This part of the population, often referred to as EWIs (entry without inspection), includes persons from nearly every country, but a large majority of them are from Mexico; most of the rest are natives of Central American countries.

Table 3.20 Removals, including deportations, exclusions and removals (FY 1999)

\begin{tabular}{|l|r}
\hline Deportable & 47,731 \\
Inadmissible & 130,825 \\
of which & \\
Criminal removals & 62,923 \\
Non-criminal removals & 115,633 \\
Total removals & 178,556 \\
\hline
\end{tabular}

Source: INS website

\subsection{NATURALIZATION}

Section 3.5 describes the policies applying to legal immigrants to become citizens of the country to which they have migrated. In addition, it focuses on the problems related to naturalization, and provides statistics on rates of naturalization.

Table 3.21 Naturalization

\begin{tabular}{|c|c|c|c|}
\hline Topics & The Netherlands & United States & Remarks \\
\hline $\begin{array}{l}\text { Principles and } \\
\text { criteria }\end{array}$ & $\begin{array}{l}\text { Principle: Stimulated by } \\
\text { government for people } \\
\text { legally residing in the } \\
\text { Netherlands for a certain } \\
\text { period. } \\
\text { Applicant must have lived } \\
\text { legally in the Netherlands } \\
\text { for } 5 \text { years or have been } \\
\text { with a Dutch partner for } 3 \\
\text { years. } \\
\text { Dual nationality: Was possi- } \\
\text { ble from ' } 92-' 97 ; \text { then again } \\
\text { rejected, albeit with many } \\
\text { exceptions. } \\
\text { Children: Ius sanguinis. } \\
\text { children born in the } \\
\text { Netherlands do not auto- } \\
\text { matically receive Dutch } \\
\text { nationality. }\end{array}$ & $\begin{array}{l}\text { No policy to stimulate/laissez- } \\
\text { faire } \\
\text { Being a legal permanent resi- } \\
\text { dent for } 5 \text { years; maintaining a } \\
\text { physical residence in us for } 30 \\
\text { months during } 5 \text { years prior to } \\
\text { the naturalization petition. } \\
\text { Dual nationality: Not en- } \\
\text { couraged, but tolerated; } \\
\text { Us does not require a new } \\
\text { citizen to take formal steps to } \\
\text { renounce his old citizenship. } \\
\text { Children: Ius soli: any child } \\
\text { born in the Us gets American } \\
\text { citizenship. }\end{array}$ & $\begin{array}{l}\text { Dual nationality: } \\
\text { Fundamental differ } \\
\text { ence in theory. } \\
\text { Children: } \\
\text { Different principles. }\end{array}$ \\
\hline Key issues & $\begin{array}{l}\text { Discussion on criteria for } \\
\text { naturalization, e.g. } \\
\text { language requirements and } \\
\text { dual nationality. }\end{array}$ & $\begin{array}{l}\text { Large number of pending } \\
\text { applications. }\end{array}$ & \\
\hline Data & $\begin{array}{l}\text { '99: } 46,088 \text { processed; and } \\
42,162 \text { approved. }\end{array}$ & $\begin{array}{l}\text { '99: } 765,346 \text { receipts, } \\
\text { 872,427 approvals/oaths } \\
\text { (3.2 per } 1000 \text { pop), } \\
\text { 379,993 denied; } \\
1,355,524 \text { pending. }\end{array}$ & $\begin{array}{l}\text { Naturalization re- } \\
\text { quests and approval } \\
\text { relatively higher in NL } \\
\text { than in US. }\end{array}$ \\
\hline
\end{tabular}




\subsubsection{PRINCIPLES}

\section{General principles and criteria}

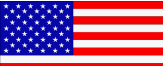

Naturalization represents the conferring of us citizenship - by any means - upon a person after birth. There are five principal ways for becoming a us citizen: naturalization in a court ceremony; naturalization through an administrative hearing; derivation through the naturalization of parents; acquisition at birth abroad to citizen parents; and legislation conferring citizenship upon certain groups of persons.

Aliens who apply to INs to become naturalized citizens have to meet certain requirements, such as residing in the us for at least 5 years as legal permanent residents, demonstrating a knowledge of the English language and American civics, and being of good moral character. The only distinction between a naturalized citizen and being an American from birth is eligibility to become President of the Us.

Foreigners who have lived in the Netherlands for at least five years are entitled to apply for Dutch citizenship. The application is processed by the IND, in co-operation with the municipality in which the applicant lives. To qualify for citizenship, the applicant must:

- be an adult (over 18);

- have lived in the Netherlands for at least five years or have been married to or cohabited with a person of Dutch nationality for at least three years;

- have an indefinite residence permit;

- be integrated into Dutch society and have a sufficient grasp of the Dutch language (this is assessed in an interview by a civil servant from the municipality in which the applicant lives);

- not have a criminal record; and

- renounce their former nationality (there are exceptions ${ }^{4}$ ).

Naturalization has the following consequences:

- registration in the municipal register as a Dutch national;

- removal from the aliens register;

- underage children automatically become Dutch citizens.

Naturalization costs 500 guilders. If a person's income is not higher than the level of a social security grant, she/he pays 250 guilders. A joint application with a spouse or partner costs 750 guilders.

The processing of a naturalization request takes between 6 and 12 months. 
Dutch citizenship is lost when:

- $\quad$ persons accept another nationality;

- persons renounce their Dutch citizenship;

- $\quad$ persons live in their country of birth for ten years at a row; and

- the decision to grant Dutch citizenship is withdrawn.

\section{Dual nationality}

The us does not encourage dual nationality, but tolerates it. If a person has been a dual citizen from birth or childhood, or else became a citizen of another country after already having us citizenship, and the other country in question does not have any laws or regulations requiring to formally renounce us citizenship before us consular officials, then current us law guarantees the right to keep both citizenships for life.

The situation is slightly less clear for someone who becomes a us citizen through naturalization and still wishes to take advantage of his old citizenship. People who go through us naturalization are required to state under oath that they are renouncing their old citizenship, and conduct inconsistent with this pledge could theoretically lead to loss of one's us status. However, the State Department is no longer actively pursuing cases of this nature in most situations. In particular, when a new American's 'old country' refuses to recognize the us naturalization oath (with its renunciatory clause) as having any effect on its own citizenship laws - and insists that the person in question must continue to deal with his old country as a citizen thereof (e.g., by using that country's passport when travelling there to visit) -, the us State Department no longer takes action. Similarly, the State Department is no longer doing anything to people who renounce their us citizenship as part of a foreign country's 'routine' naturalization procedure (in a manner similar to what theus makes its new citizens do). However, if the other country in question requires its newly naturalized citizens to approach officials of their old countries to revoke their previous status, one will generally not be able to remain a citizen both of that country and the us.

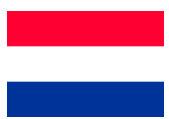

Dual nationality was possible in the Netherlands in the period between 1992-1997; but was then once again rejected in principle, albeit it with many exceptions. People obtaining Dutch citizenship have to renounce their formal nationality, unless there are good reasons not to do so (these reasons might, for example, that the country of original nationality does not accept the loss of nationality, or that it can be demonstrated that loss of the other nationality would lead to serious financial losses). 


\section{Children}

The Citizenship Clause of the Fourteenth Amendment guarantees citizenship to

"All persons born... in the us, and subject to the jurisdiction thereof."

The Netherlands Republic Citizenship Act (Rijkswet op het Nederlanderschap) states that children automatically get the Dutch citizenship when one of their parents is Dutch. In addition, children adopted by Dutch parents also get Dutch citizenship. Children of non-Dutch parents who are born in the Netherlands do not automatically receive Dutch nationality.

\subsubsection{KEY ISSUES}

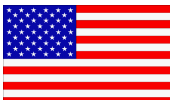

A recurrent theme in the naturalization arena is the large number of pending applications. In FY 1994, the INs had some 300,000 applications pending and received approximately 600,000 applications during the fiscal year. Over the next four years, the INS received almost 5 million applications, and approached 2 million pending by the end of FY 1998. The large increase in applications is attributable to the passage of the 1996 welfare reform legislation that restricted access of recent immigrants to federal public benefits (see section 4.3). As things have settled and the worst predictions about the effects of the legislation did not come to pass, the number of applications for naturalization has declined.

The INS reduced the number of pending cases by 500,000 during FY 1999, the first year of a two-year naturalization program effort. Specific measures taken to decrease the backlog and lower waiting times (the average application processing time went from 27 months in 1998 to 12 months in 1999) include:

- A streamlined naturalization program;

- Completion goals coupled with a multi-year plan to address backlogs;

- Additional budget funding (to reduce backlogs and improve procedures). A second theme relates to the criteria for citizenship. For example, some have called for a change in the granting of automatic citizenship to children born in the Us by non-citizen parents. 5 Others are debating the minimal language and civics/ history requirements for naturalization. Other problems that have been identified include problems in obtaining and using the results of the aliens' criminal history records; and problems with fraud by private companies on which INs relied to test applicants' knowledge of English and civics. 
There has been some discussion in the Netherlands about the new naturalization procedures, generally speaking more about issues such as language requirements (whether knowledge of the Dutch language is required for acquiring Dutch citizenship, and how it is to be established) and dual nationality (especially the required rejection of the previous nationality), than about the overall naturalization numbers (which proportionally lie significantly above those of the Us).

\subsubsection{STATISTICS}

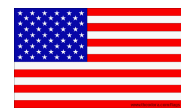

Cohorts are followed in time to gain an idea about what percentage of immigrants actually become American citizens at some moment in time. The table below shows that 48 per cent of the 1982 cohort had naturalized by the end of 1997.

Table 3.22 Naturalization rates through FY 1997 of immigrants admitted in 1982

\begin{tabular}{l|l|c}
\hline \multicolumn{1}{c|}{58} & $\mathbf{1 9 8 2}$ \\
\hline \multirow{2}{*}{$\quad \begin{array}{l}\text { Age: } \\
\text { 16-34 years }\end{array}$} & 53.5 \\
35-54 years & 45.1 \\
55 years and over & 23.8 \\
Gender: & \\
Female & 49.3 \\
Male & 47.4 \\
Class of admissions: & 42.6 \\
Family preference & 53.0 \\
Employment pref. & 62.1 \\
Refugee/Asylee & 49.4 \\
Other & $\mathbf{4 8 . 2}$ \\
Total naturalized & \multicolumn{2}{|c}{ Source: 1997 Statistical Yearbook of the INS. }
\end{tabular}


Table 3.23 Naturalization by country of origin (1999)

\begin{tabular}{|l|r}
\hline Previous citizenship & Number \\
\hline Belgium & 200 \\
China & 800 \\
Germany & 600 \\
France & 200 \\
Indonesia & 400 \\
Italy & 300 \\
Morocco & 11300 \\
Pakistan & 300 \\
Portugal & 200 \\
Spain & 100 \\
Surinam & 3000 \\
Turkey & 13500 \\
United Kingdom & 600 \\
Unites States & 300 \\
Other & 26400 \\
Without and unknown & 1200 \\
Total & $\mathbf{5 9 2 0 0}$ \\
\hline
\end{tabular}

Source: CBS (2000: 76)

\subsection{RETURN MIGRATION}

Section 3.6 describes the Dutch policy to stimulate return migration, i.e. the policy to stimulate immigrants to the Netherlands to return to their home country by providing economic incentives. This policy option is not known and not considered in the Us.

Table 3.24 Return migration

\begin{tabular}{|l|ll}
\hline Topics & The Netherlands & United States \\
\hline Principle & $\begin{array}{l}\text { Facilities for } 1^{\text {st }} \text { and } 2^{\text {nd }} \text { generation } \\
\text { immigrants who wish to resettle in their } \\
\text { country of origin, but have no means to } \\
\text { do so (new law since April 2000) }\end{array}$ \\
Provisions & $\begin{array}{l}\text { Basic allowance (travel and relocation } \\
\text { plus living allowance for 2 months); for } \\
\text { certain categories also health insurance, } \\
\text { liberal visa regime for family visits, } \\
\text { indexation of monthly allowance, return } \\
\text { option after one year }\end{array}$ \\
\hline In April 2000,6000 people entitled to \\
these provisions (mostly in FY and \\
Morocco); in 97 and 98 300 new cases \\
(out of 650 applications); in 1999, 235
\end{tabular}




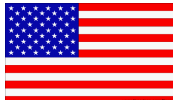

The us does not have a return policy.

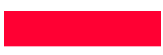

The Netherlands has a liberal return ('remigration') policy. Because of its generous social provisions, the calculation was been made that it would be cheaper to provide migrants with travel and relocation costs to their country of origin and even to send them various allowances there, than to continue to pay all of the Dutch social entitlements in case the migrant would stay in the Netherlands.

\subsection{BILATERAL COMPARISON OF IMMIGRATION RELATED ISSUES}

\section{Governance}

In both the us and the Netherlands, immigration-related issues are entirely governed at the national level of government. However, with the growing European unification, there is discussion about some of the immigration policies moving up to a supranational policy level.

\section{Categories}

With respect to the admission and the enforcement components of immigration policy, the us was found to put relatively more emphasis on the enforcement component, and the Netherlands on the admission component. With respect to 'shaping' it was suggested that both the Us and the Netherlands (the Netherlands especially in an EY context) could benefit from a more conscious 'shaping'-policy.

\section{Regular immigration}

Although both countries restrict entry into their countries, us admission policies for regular immigrants appear to be more liberal than the Dutch ones - with the important exception of extremely liberal provisions for citizens from other EUcountries - both in theory and in practice. Despite these restrictionist policies, both countries are still experiencing historically high (in the case of the Netherlands even unprecedented) immigration levels.

Some striking differences:

- the use of immigration to cover critical high-skill shortages in the us labor market;

- $\quad$ Us policies to stimulate 'diversity' through immigration;

- the relatively much higher emigration rates in the Netherlands.

The Netherlands would probably be well served by a debate on the use of immigration policy as a tool to attract needed human capital (critical skills), and on ways to implement such a policy (through quotas, auctions, etc.). Refocusing attention on labor migration also may make migration movements more con- 
trollable and more subject to regulation (so that people immigrating for economic motives are no longer dependent upon irregular migration groups) - the expectation being that the number of illegals and the number of asylum-seekers without good grounds would decline.

\section{Asylees and refugees}

Both countries adhere to the 1951 Geneva Convention on refugees, and while they apply slightly different criteria to implement it, the principles are very similar. On the other hand, the procedures in both countries differ significantly, with the us generally choosing for a faster and more minimalist approach towards asylumseekers and refugees, and the Netherlands opting for more generous and lengthier provisions. The Netherlands also has significantly higher approval rates and larger number of resident refugees.

Although there is little hard evidence to corroborate this hypothesis, these differences may suggest a link between a state's policy towards regular migration and towards asylum: if regular migration is impeded in a variety of ways, the asylum procedure (and especially a generous one) may be used as an alternative way to gain admission into a country.

\section{Return migration}

The Netherlands implements a remarkable generous return policy, which has no equivalent in the US. It may be worthwhile to observe that this policy might send signals to prospective immigrants that appear to be at odds with the restrictionist nature of the overall policy towards regular immigration.

\section{Naturalization}

Naturalization principles and practices are generally speaking quite similar in both countries. The most striking differences in this area are:

- The difference in dual nationality (at least de iure, where the us accepts, and the Netherlands no longer accept, dual nationality;

- The differences for immigrant children, who automatically receive us citizenship if they are born in the Us, but do not receive Dutch nationality if they are born in the Netherlands

\section{Illegal immigrants}

Illegal immigrants in both countries have officially speaking no rights to stay in the country, although both countries do provide some forms of public assistance.

The us appears to have stricter practices on detection and removal of illegal immigrants. 


\section{NOTES}

1 Other immigrant services include immigrant and non-immigrant sponsorship, adjustment of status, work authorization and other permits, naturalization, and refugee and asylum.

2 The Economic European Area includes the European Union member states and Norway, Liechtenstein and Iceland.

3 Illegal immigrants who have been working in the Netherlands for six years in a row and who were eligible for a residence permit until 1 January 1998.

4 These exceptions include: when the country of original nationality does not accept the loss of nationality; when it can be demonstrated that loss of the other nationality would lead to serious financial losses (e.g. because of inheritance regulations), etc.

5 This would require an amendment to the us Constitution - never an easy accomplishment. 


\section{BILATERAL COMPARISON OF INTEGRATION RELATED} ISSUES

This chapter describes the key problems, government policies and divisions of responsibilities with respect to the social-structural dimensions of integration. It focuses on how immigrants fare in education, the labor market, social welfare, and housing. The degree to which natives and immigrants differ gives an indication about the degree to which immigrants are successfully integrated. However, these variables are not the sole indicators of integration. For a more complete view of integration, other factors, such as acceptance, discrimination, and political participation should also be taken into account. However, these factors fall outside the scope of this current study.

In both the Netherlands and the Us, policies are in place in diverse areas relating to integration of immigrants. These general policies are often supported by groupspecific policies aimed at immigrants. The group-specific policies are justified at the grounds that immigrants have specific problems or that general policies fail to address immigrants. In both the Netherlands and the us general policies are focused on the disadvantaged groups. For the analysis of the us situation, it is extremely important not to confuse the problems of disadvantaged groups, such as African Americans, and the problems of immigrants. For example, the formation of ghettos and the problems related to that are not considered to be an immigrationrelated problem in the Us.

Responsibilities for integration of immigrants in both the Netherlands and the Us, do not only rest with the national government. In the us, the federal government plays only a minor role in integration; in the Netherlands, the national government has the most important role, but provinces and municipalities are also involved. It is outside the scope of this project to describe all integration-related activities of subnational governments, but where state responsibilities in the us correspond to national responsibilities in the Netherlands, we will look to California.

In this chapter, statistics are presented with respect to the social-structural dimensions of integration. It is important to stress that these data should be interpreted with care. In the us and the Netherlands, different definitions are used for who are immigrants, what constitutes higher education, and what welfare state arrangements comprise. In addition, there are large differences between the characteristics of immigrants to the Us and the Netherlands, for example with respect to nation of origin and educational level. Finally, some tables in this chapter give statistics on the us by racial breakdowns, which does not (necessarily) provide a picture of the differences between natives and immigrants. Therefore direct data comparisons are difficult. 


\subsection{EDUCATION}

Section 4.1 focuses on general and group-specific education policies that have an effect on integration of immigrants. In addition, it describes the key problems addressed by these policies, and gives some statistics to give an impression of the degree of integration of immigrants. The problems, policies, and statistics address three key aspects of education, namely access to education, participation of immigrants in different types of education, and performance in the education system.

\section{Table 4.1 Overview of education issues and policies}

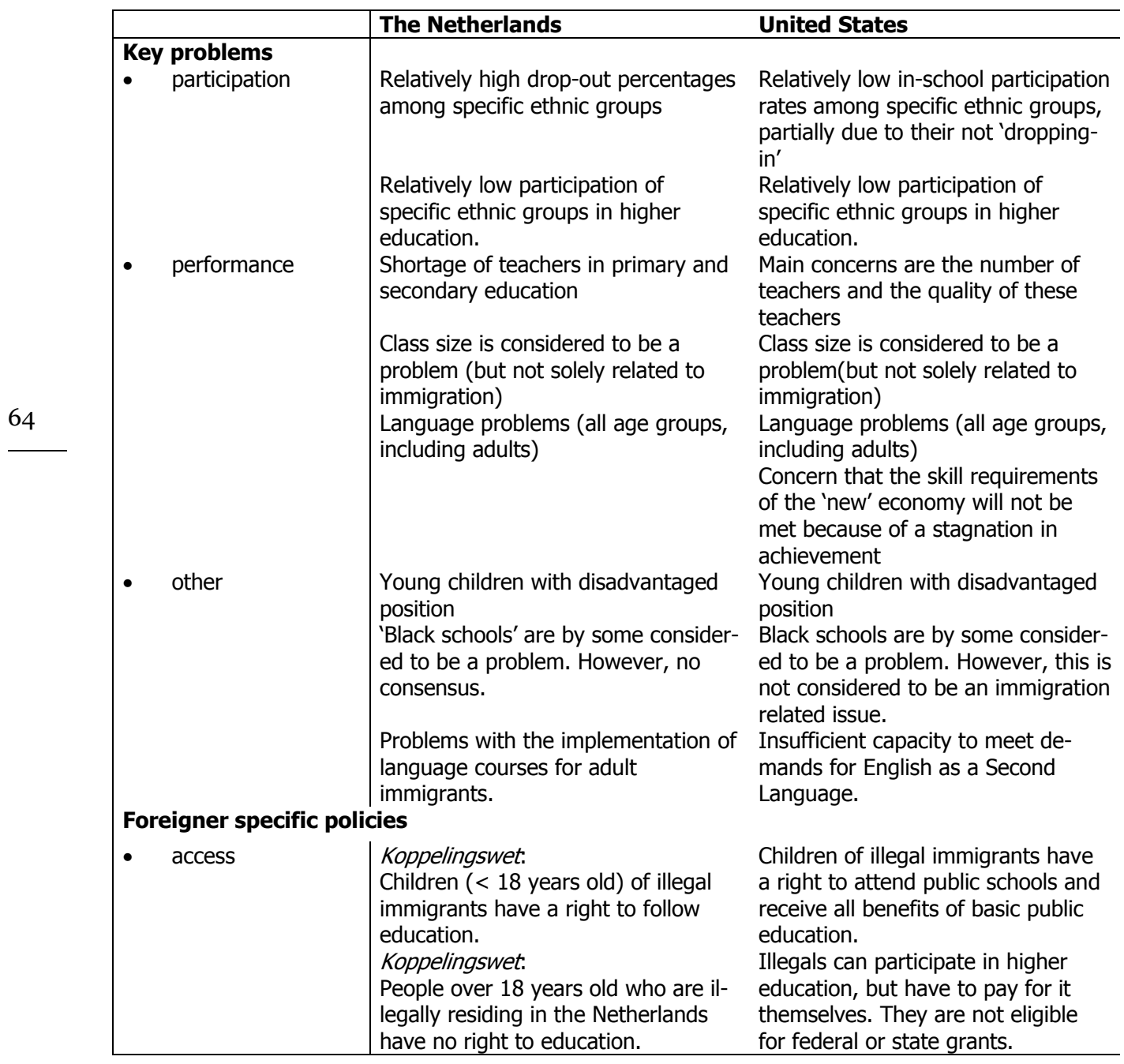




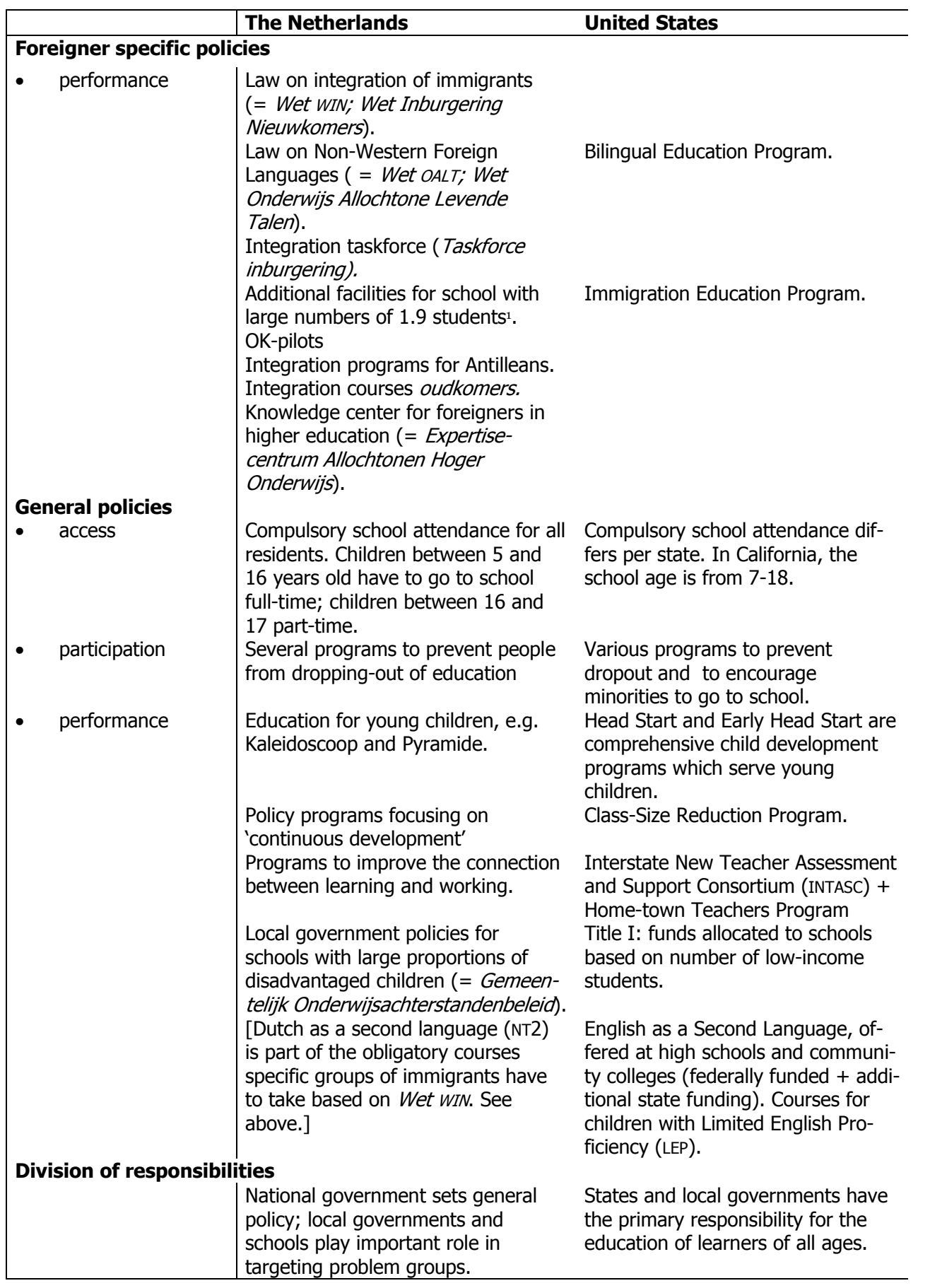




\begin{tabular}{|c|c|c|}
\hline & The Netherlands & United States \\
\hline $\begin{array}{l}\text { Statistics } \\
\text { - participation }\end{array}$ & $\begin{array}{l}\text { In the Netherlands, approximately } \\
13 \% \text { of the students in primary edu- } \\
\text { cation are } 1.9 \text { students. These per- } \\
\text { centages are much higher in the big } \\
\text { cities, e.g. approximately } 50 \% \text { in } \\
\text { Amsterdam and Rotterdam. } \\
\text { Participation of natives in higher } \\
\text { education ( } 24.4 \% \text { of male) is much } \\
\text { higher than that of non-western } \\
\text { foreigners. } \\
\text { Natives ( } 4 \% \text { ) less often drop out of } \\
\text { school than non-western foreigners. } \\
\text { Nine-year old natives perform better } \\
\text { in doing sums ( } 585 \text { points) than } \\
\text { foreign-born students ( } 550 \text { points). }\end{array}$ & $\begin{array}{l}\text { Participation of natives with a } \\
\text { bachelors' degree or higher ( } 25 \%) \\
\text { is much higher than that of Central } \\
\text { Americans, but lower than that of } \\
\text { Asians. } \\
\text { Natives ( } 8 \% \text { ) less often drop out of } \\
\text { school than non-western foreigners. } \\
\text { Nine-year old natives perform better } \\
\text { in doing sums ( } 553 \text { points) than } \\
\text { foreign-born students ( } 518 \text { points). }\end{array}$ \\
\hline
\end{tabular}

\subsubsection{KEY ISSUES}

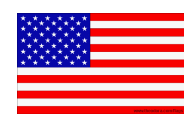

\section{Access}

Dropouts: Immigrant children and youths are as likely as natives to enroll in primary and middle schools (i.e. $1^{\text {st }}$ through $8^{\text {th }}$ grade). Nonetheless, they are somewhat less likely than natives to attend high school ( $9^{\text {th }}$ through $12^{\text {th }}$ grade). For example, in 1990, participation rates were 87 and 93 percent for immigrant children and natives respectively; the differential was accounted for by immigrant youths of Hispanic origin, primarily from Mexico. Recent statistics suggest that one in every four immigrants from Mexico in the 15-17 age group was not in school in 1990 (Vernez 1996: xii).

As such, the relatively low in-school participation rates for Mexican immigrants is partially due to them not 'dropping in' as opposed to 'dropping out'. These youth decide not to enroll in schools for a variety of reasons: by choice, because of inability to catch others their age or native counterparts, or due to economic necessity (Vernez 1996: xiii).

Participation of immigrants in higher education: Conditional on having been enrolled in a us high school by grade 10, immigrant students are more likely than their native counterparts to make choices consistent with pursuing a college education (e.g. taking advanced placement courses). They are more likely to follow an academic track and enroll in mathematics and science courses. These differences in course taking patterns hold both in the aggregate and within each racial/ ethnic group. There are, however, variations within the 'immigrant' category. Asian immigrants typically performed best on indicators of preparation for college, follow- 
ed by White and Black immigrants. Hispanic immigrants performed lowest on nearly all indicators of college preparation. While four out five Asian high school graduates go on to college, merely one in two Hispanic high school graduates do the same (Vernez 1996: xiii).

\section{Performance}

Language problems: Many of the immigrant children entering the us educational system have to overcome poor academic preparation in their country of origin and nearly all have to learn English as well as new institutional and cultural norms. This issue persists even though many schools have developed courses of instruction that are especially designed for the needs of LEP (Limited English Proficiency) students. This may be partially due to the fact that no particular program of instruction is required, as long as the students' needs are effectively met. Courses for LEP students may include disproportionate enrolments of national origin minority students; the caveat being that they must be designed to allow students to move into regular classes within a reasonable period of time. This problem persists, because there is not sufficient capacity to meet current ESL demands.

Class size: Class size is currently a hot topic in the Us. Some studies have been conducted on the potential educational attainment for students in smaller classes. Currently, a growing body of research suggests that students attending small classes in the early grades make more rapid educational progress than students in larger classes. More importantly, it is believed that these achievement gains persist after students move on to larger classes in later grades. Currently, the classes are considered to be too large.

Capacity constraints, shortage of teachers and quality of teachers: Capacity constraints are being experienced in the school system as increasingly larger cohorts of school children are entering the system each year, effectively putting a strain on resources such as books, infrastructure, teachers, etc. These shortages are also present in the secondary school system. Class size limits exacerbate this problem.

Linked to the issue of teacher shortage is the growing concern regarding teacher quality. A perceived decrease in the ability of graduating students (for example in the areas of reading and math) has led to increasing questioning of teacher credentials. There is growing consensus that there is a need for tougher standards for licensing new teachers and more rigorous requirements in hiring teachers.

Currently, states vary widely in the processes and standards used to license classroom teachers.

\section{Other}

Black schools: The issue of 'black schools', i.e. schools with a relatively large percentage of African Americans, is not specifically related to immigration. Black immigrants to the us are generally well educated and their children perform relatively well and better than African Americans. While there is concern about Black 
educational performance, there is now equal concern about the performance of Hispanic students because they are the fastest growing minority in the us and because they do not do well at school.

Dropouts: There is special concern about the relatively high percentage of people (between 15 and 24 years old) leaving secondary school without any qualifications. The problem is especially large among specific ethnic groups, such as Turks (23\%), Antilleans and Arubans (15\%), and Moroccans (14\%).

Low participation in higher education: Relatively low participation of specific ethnic groups in higher education. The main problem groups are Turks and Moroccans.

\section{Performance}

Shortage of teachers in primary and secondary education: One of the major concerns with respect to the Dutch education system is the shortage of teachers, in both primary and secondary education. This is a general problem that is not specifically related to immigration. However, it might effect the performance of immigrants. This problem is closely related to the problem of class size.

Language problems (all age groups, including adults): Students who have difficulties with the Dutch language have difficulties catching up in the Dutch education system.

\section{Other}

Young children with a disadvantaged position: 4-or 5-year-old children of immigrants already have a disadvantaged position as they start school, mainly because of language problems, but also because of relatively low social competencies. This problem continues through their school career as they have difficulties catching up.

'Black schools' are considered to be a problem. An issue that is currently often debated is integration vs. segregation at schools and the ways this effects the quality of the schools. However, there is no consensus on this issue.

Problems with implementation of language courses for adult immigrants: There are several problems with the implementation of language courses for adult immigrants. On the one hand, there are long waiting lists for language courses for immigrants who have been in the Netherlands for quite some time (= oudkomers). On the other hand, the budget available for these courses is not totally spent. In addition, a high percentage of the people enrolled in the courses drop out before they reach the desired level of Dutch. Finally, the Algemene Rekenkamer noted 
that the available sanctions for dropping-out are not optimally applied (Algemene Rekenkamer 2000).

\subsubsection{GOVERNMENT POLICIES}

In the US, states and local governments have the primary responsibility for the education at all ages. It is the individual states and communities (including public and private organizations) that establish schools and colleges, develop curricula, and determine requirements for enrolment and graduation. It is important to mention that the us has an extensive network of private schools, colleges and universities.

\section{Access}

Compulsory education: Without regard to citizenship/immigration status, all children have a constitutional right to attend public schools - Kindergarten through $12^{\text {th }}$ grade - and receive all benefits of 'basic public education' (California Department of Education). This includes both us born children of illegal parents and illegal immigrants' children.

Higher education: Higher education is not free. The price to attend these institutions depends upon the type of school, e.g. is it a community college (2 years), state college, state university, or private college/university. Nonetheless, all immigrants can enroll in higher education, but all illegals are not eligible for federal/ state grants and loans.

\section{Performance}

Class-Size Reduction Program: An initiative to help schools improve student learning by hiring additional (qualified) teachers so that children, especially those in the early elementary grades, can attend smaller classes. The goal of the program is to help schools hire 100,000 new teachers and reduce class size in the early grades ( $\mathrm{K}$ through $3^{\mathrm{rd}}$ ) from 32 to 20 in the next seven years.

Teacher quality: Presently, the Interstate New Teacher Assessment and Support Consortium (INTASC), in collaboration with the Council of Chief State School Officers, is working with more than 30 states to develop high-quality performance assessments of knowledge and skills for beginning teachers. These standards are to be related directly to academic standards for students. Requiring tougher licensing and certification standards for teachers seems to be drawing significant support from those who already are teachers, with 86 percent supporting competency requirements before obtaining certification.

In addition, in 2001 a Hometown Teachers program will be implemented to help school districts develop their own teachers and to 
review and reward quality teachers in high poverty districts,

b provide additional funds to encourage mid-career professionals to become teachers,

c provide additional funding to help train early childhood educators, and

d support for the recruitment and training of school leaders, especially in highpoverty and low-performing districts.

Bilingual education: In 1968, Congress passed the Bilingual Education Act in recognition of the growing number of linguistically and culturally diverse in schools. The Office of Bilingual Education and Minority Languages Affairs, established in 1974 by Congress, helps school districts meet their responsibility to provide equal education opportunity to LEP children (Us Department of Education, Office of Bilingual Education and Minority Language Affairs).

With respect to numbers, there is a large portion of students who fit the LEP category. According to a 1997 study of the National Center for Education Statistics study, over 42 per cent of public school teachers in the us (or just over 1 million teachers) reported having LEP students.

To support the needs of LEP populations, some schools offer bilingual education. In 1995, the Bilingual Education program served some 440,ooo students. Nonetheless, there are differing viewpoints vis-à-vis the need of bilingual education. For example, while the Denver public school district has expressed that there is an historic level of 50 percent unqualified bilingual teachers in their district, the state of California voted to end bilingual education ${ }^{2}$ with Proposition 227 in 1998. In a similar vein, Arizona recently voted to end bilingual education.

Supporters of the measure complained that some Spanish-speaking students in the state have spent over eight years in bilingual classes intended to serve as a transition to mainstream English courses. In both states, children who are not sufficiently fluent in English are to be placed in English immersion classes for one year and then returned to mainstream studies.

Immigrant Education program: There is an Immigrant Education program that provides assistance to local educational agencies with concentrations of recent immigrant students. In FY 1997 allocation was $\$ 100$ million. According to the Budget Service (February 7, 2000), 150 million dollars were appropriated for immigrant education in FY 2000.

English as a Second Language (ESL): ESL is targeted for individuals of all ages who intend to improve their English skills. This section focuses on adult ESL (which is offered at high schools and community colleges).

In 1999, there were 1,695,516 adults enrolled in ESL programs that received funding through the us Department of Education's Office of Vocational and Adult Education (OvAE). This figure represents 47 percent of the overall national adult 
education enrolment of $3,616,391$ learners. There is additional funding from the states.

Other programs: There are several programs that serve large numbers of disadvantaged students, many of whom are recent immigrants, e.g. Head Start and Title I. Head Start and Early Head Start are comprehensive child development programs which serve children from birth to age 5 . The goals is to increase school readiness of young children in low-income families. Title I are funds allocated by districts to schools based on number of low-income students.

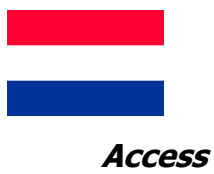

Compulsory school attendance: School attendance is compulsory for all residents (incl. legal immigrants) of the Netherlands. The school age for full-time attendance is from 5-16. From age 16-17, part-time school attendance is compulsory.

Koppelingswet: The Koppelingswet is a law that makes it possible to couple information from the administration of the local government and of the foreigner administration system. Coupling these databases makes it possible to track illegal foreigners. With respect to education, it is noted that children $(<18$ years old) of illegal immigrants have a right to education. The law makes it possible to track illegal students, but this has no consequences for the students. Children over 18 years old have no right to education. Based on this law, universities have to check whether students are legally residing in the Netherlands. If not, they have to be expelled from university.

\section{Performance}

Law on integration of immigrants (= Wet WIN; Wet Inburgering Nieuwkomers): Specific groups of new immigrants (nieuwkomers) have the obligation to follow Dutch language courses (NT2) and courses about Dutch society (cursussen maatschappelijke oriëntatie). During the intake of the immigrants, it is decided whether people have to follow these courses or not.

Law on Non-Western Foreign Languages ( = Wet OALT; Wet Onderwijs Allochtone Levende Talen): Children of immigrants get support to learn Dutch and their own language. These lessons are taking place outside the regular school curriculum.

Integration taskforce (Taskforce inburgering): A government taskforce that is specifically focusing on integration, e.g. on policy measures to reduce waiting lists for adult language education. 
Additional facilities for school with large numbers of 1.9 students: Schools with large numbers of students with disadvantaged position get additional facilities, such as additional budget to buy computers and education programs.

OK-pilots: Policy to attract more non-western foreigners to become teachers and to increase the school success of non-western foreigners.

Integration programs for Antilleans: In the Netherlands Antilles, people who plan to go to the Netherlands can take courses to prepare them for Dutch education.

Language courses for oudkomers: Dutch language course and courses in social competencies for immigrants who have been in the Netherlands for quite some time (= oudkomers), but are not very well integrated.

There are several general programs that serve disadvantaged students, many of whom are recent immigrants.

Education for young children (o-4 years): Currently, some projects are being implemented to make sure that children do not have a deprived position even before they start school, e.g. Kaleidoscoop and Pyramide.

Policy programs focusing on continuous development: Several organizations work together to make sure that people are 'guided' through the education system. Local government policies: Local governments have specific policies for schools with large proportions of children from deprived positions (= Gemeentelijk Onderwijsachterstandenbeleid).

Knowledge center for foreigners in higher education: An institute offering advice to foreigners in higher education (= Expertisecentrum Allochtonen Hoger Onderwijs).

\subsubsection{STATISTICS}

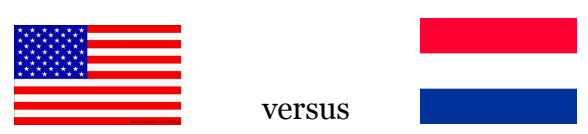

\section{Population in primary education}

Table 4.2 NL: Percentages 1,9-students in primary education

\begin{tabular}{|l|l}
\hline Netherlands & $12.6 \%$ \\
Amsterdam & $50.4 \%$ \\
Rotterdam & $49.9 \%$ \\
The Hague & $40.6 \%$ \\
Utrecht & $38.5 \%$ \\
\hline
\end{tabular}

Source: Oc\&W (2000: 9) 
Table 4.3 NL: Percentage of children from cultural minorities (= cumi-leerlingen) in primary education

\begin{tabular}{|l|r|}
\hline Schools without cumi-leerlingen & $21 \%$ \\
Schools with cumi-leerlingen & $79 \%$ \\
$-0-10 \%$ & $49 \%$ \\
$-11-20 \%$ & $12 \%$ \\
$-21-30 \%$ & $5 \%$ \\
$-31-40 \%$ & $3 \%$ \\
$-41-50 \%$ & $2 \%$ \\
$-51-60 \%$ & $2 \%$ \\
$->60 \%$ & $6 \%$ \\
\hline \multicolumn{2}{|c|}{ Source: CBS (2000: 83$)$} \\
\hline
\end{tabular}

Table 4.4 US: Immigrant contribution to school population (1998; \% with immigrant mothers)

\begin{tabular}{|c|l}
\hline & $\begin{array}{l}\text { School-age } \\
\text { population } \\
(\mathbf{5 - 1 7} \text { years old })\end{array}$ \\
\hline United States & \multicolumn{1}{|c}{$15.9 \%$} \\
\hline \multicolumn{2}{|c|}{ Source: Camarota (1999: 10$)$}
\end{tabular}

Table 4.5 US: 1999/2000 enrolment in California's primary education (racial breakdowns; not necessarily immigrants)

\begin{tabular}{|l|r|}
\hline Hispanic & $42.2 \%$ \\
White & $36.9 \%$ \\
Asian and Pacific Islander & $11.0 \%$ \\
African American & $8.6 \%$ \\
American Indian & $0.9 \%$ \\
\hline
\end{tabular}

Source: www.cde.ca.gov

\section{Participation in tertiary education}

Table 4.6 NL: Higher educational attainment (HBO/wo) by ethnicity and gender (1999)

\begin{tabular}{|l|rr}
\hline & Male & Female \\
\hline Turks & $5,5 \%$ & $2,5 \%$ \\
Moroccans & $5,9 \%$ & $2,1 \%$ \\
Surinamese & $16,3 \%$ & $13,7 \%$ \\
Antilleans & $19,8 \%$ & $11,9 \%$ \\
Southern Europeans & $13,0 \%$ & $15,9 \%$ \\
Other countries & $24,7 \%$ & $19,2 \%$ \\
Western Europeans / Americans & $33,2 \%$ & $29,8 \%$ \\
$\quad$ (US) & & \\
Netherlands & $24,4 \%$ & $18,9 \%$ \\
\hline
\end{tabular}

Source: SCP (1999: 62) 
Table 4.7 US: Higher educational attainment (bachelor's or advanced degree) by region of origin (1999)

\begin{tabular}{|l|r}
\hline Natives & $25.1 \%$ \\
Europe & $30.0 \%$ \\
Asia & $35.3 \%$ \\
Central America * & $5.8 \%$ \\
\hline \multicolumn{2}{|c|}{ * includes Mexico but does not include South America and the Caribbean } \\
Source: us Bureau of the Census Current Population Survey (March 1999)
\end{tabular}

\section{Performance in primary education}

Table 4.8 NL + US: Performance (as measured by the Third International Mathematics and Science Study) of 9-year old in doing sums

\begin{tabular}{|l|rrr}
\hline Country & $\begin{array}{r}\text { Foreign-born } \\
\text { population }\end{array}$ & Natives & Difference \\
\hline Scotland & 529 & 520 & -9 \\
Ireland & 543 & 552 & 9 \\
England & 504 & 518 & 14 \\
Austria & 533 & 566 & 33 \\
United States & 518 & 553 & 35 \\
Netherlands & 550 & 585 & 35 \\
\hline
\end{tabular}

Source: Oc\&W (2000:24)

Drop-out percentages

Table 4.9 NL: Percentage of people (15-24 years) leaving secondary school without any qualifications, by ethnic group

\begin{tabular}{|l|r}
\hline Natives & $4 \%$ \\
Turks & $23 \%$ \\
Moroccans & $14 \%$ \\
Surinamese & $10 \%$ \\
Antilleans/Arubans & $15 \%$ \\
\hline
\end{tabular}

Table 4.10 us: Percentage of drop-outs (16-24 years) from the education system, by ethnic group

\begin{tabular}{|l|r}
\hline Non-Hispanic White & $7.6 \%$ \\
Non-Hispanic Black & $13.4 \%$ \\
Hispanic & $25.3 \%$ \\
\hline
\end{tabular}

\subsection{EMPLOYMENT}

Section 4.2 pays attention to the degree of integration of immigrants into the economy. It focuses on the key problems of immigrants in the labor market, and describes foreigner specific and general policies that are implemented to address 
these problems. Finally, it gives statistics on unemployment, labor market participation and self-employment.

Table 4.11 Overview of employment issues and policies

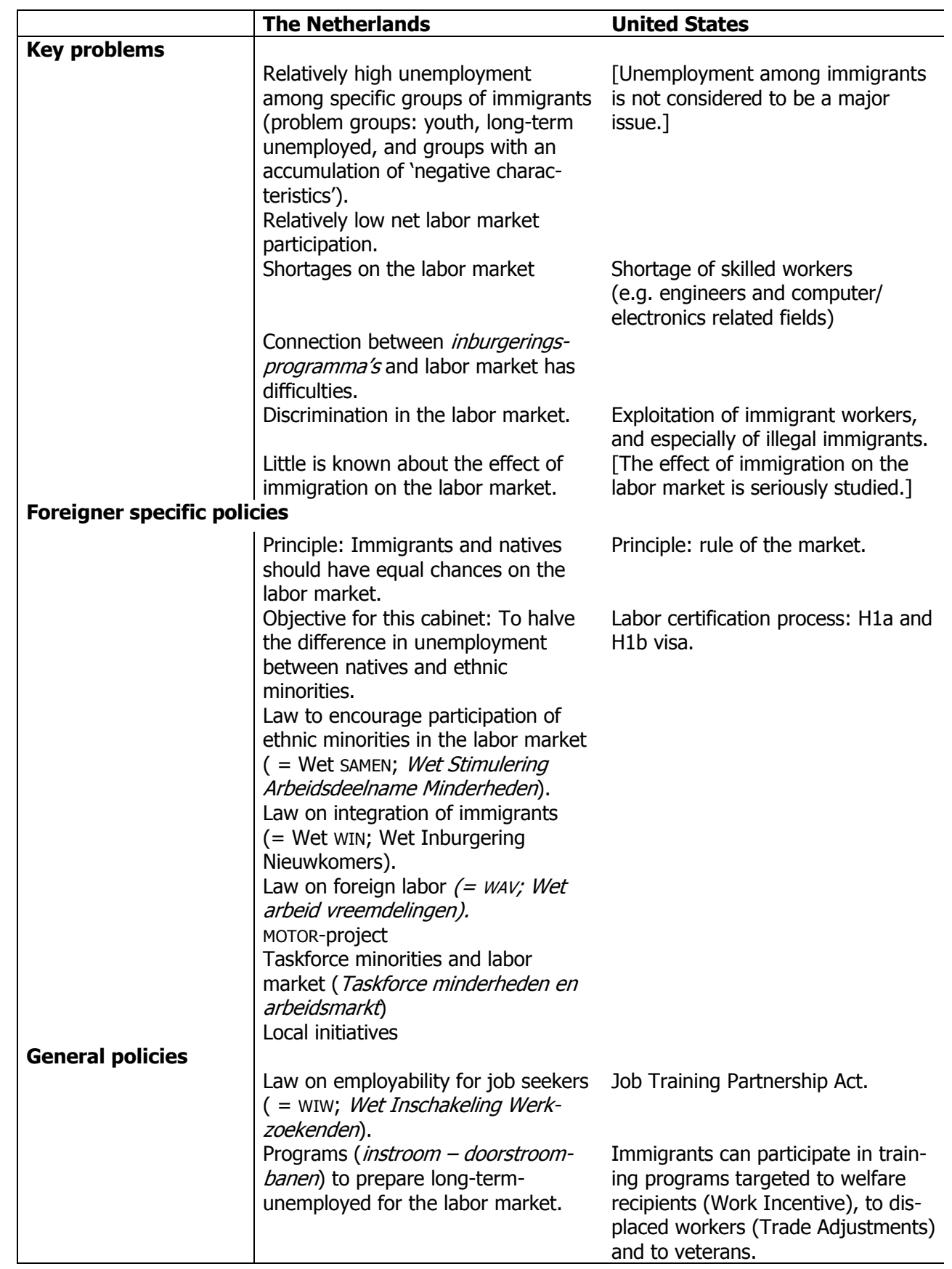




\begin{tabular}{|c|c|c|}
\hline & The Netherlands & United States \\
\hline \multicolumn{3}{|c|}{ Division of responsibilities } \\
\hline & $\begin{array}{l}\text { The national government is respon- } \\
\text { sible for designing labor market pol- } \\
\text { icies. Local government and govern- } \\
\text { mental organizations (such as } \\
\text { Regional education centers (Regio- } \\
\text { nale Opleidings Centra) and Employ- } \\
\text { ment Exchange agencies (Arbeids- } \\
\text { bureaus)) are responsible for the } \\
\text { implementation of these programs. }\end{array}$ & $\begin{array}{l}\text { Federal government programs play } \\
\text { a small role in actual provision of } \\
\text { training. } \\
\text { State and local governments, to- } \\
\text { gether with the private sector, have } \\
\text { primary responsibility for develop- } \\
\text { ment, management, and adminis- } \\
\text { tration of training programs under } \\
\text { JTPA. }\end{array}$ \\
\hline \multirow[t]{3}{*}{ Statistics } & & \\
\hline & $\begin{array}{l}\text { Unemployment among natives ( } 3 \%) \\
\text { is much lower than unemployment } \\
\text { among non-western foreigners } \\
(14 \%) \text {. } \\
\text { Labor force participation among } \\
\text { natives ( } 66 \%) \text { is much higher than } \\
\text { among non-western foreigners } \\
(45 \%) \text {. }\end{array}$ & $\begin{array}{l}\text { Unemployment among natives } \\
(5.4 \%) \text { is slightly lower than unem- } \\
\text { ployment among non-western } \\
\text { foreigners }(6.9 \%) \text {. } \\
\text { Labor force participation for natives } \\
\text { and Hispanics are approximately } \\
\text { similar (resp. } 67 \text { and } 68 \%) \text {. }\end{array}$ \\
\hline & $\begin{array}{l}\text { Self-employment rates among } \\
\text { natives are } 10 \% \text {. For some ethnic } \\
\text { groups these rates are higher; for } \\
\text { other groups lower. }\end{array}$ & $\begin{array}{l}\text { Self-employment rates among } \\
\text { natives are } 13 \% \text { for male and } 7 \% \\
\text { for female population. For some } \\
\text { ethnic groups these rates are } \\
\text { higher; for other groups lower. }\end{array}$ \\
\hline
\end{tabular}

\subsubsection{KEY ISSUES}

Unemployment: In March 1997, the unemployment rate was higher for the foreign-born labor force as a whole (6.9\%) when compared to the native labor force (5.4 \%). In spite of these statistics, unemployment is not a major immigration related issue in the Us - especially given the strength of the economy in the past years.

Shortage of skilled workers: According to us employers, it is difficult to get qualified workers for several specialized occupations (e.g. engineers and computer/ electronics related fields). This is one of the foundations for the $\mathrm{H}-1 \mathrm{~B}$ program described earlier. There currently are programs being executed to bridge this gap so that there is less reliance on foreign workers. For example, in July 200o, the Us Department of Labor announced a second of three rounds of demonstration grants for training American workers for high-skill jobs in areas where companies are facing labor shortages. The $\$ 29$ million round is part of nearly $\$ 80$ million the Labor Department will invest during 2000 in fees received through the $\mathrm{H} 1-\mathrm{B}$ visa program. The funds are geared to enable American workers to receive high-tech training in areas such as network design, digital media, systems analysis, telecommunications, programming, nursing, bioscience, and animation. 
Labor exploitation: There is evidence to suggest that some immigrant workers are exploited - almost to the point of indenture. This happens more frequently with illegal immigrants who are at the mercy of employers for employment. Without the ability to place demands, they may end up earning below minimum wage in a sweatshop type environment (raising human rights issues).

Wage effects: In the us many studies addressed the question whether immigrants complement us workers and raise their average wage, or whether immigrants substitute for natives, thus lowering native wages. Research on this topic has been on going since the early eighties. Most studies reveal only small national-level effects of all immigrants on the wages of us residents in the 1980. Rather, immigrants have a large impact on the bottom end of the labor market (people with less than 12 years education). The wage impact had been to decrease both the wages of the native underclass and the wages of the foreign-born population already in the Us. In addition, there is a downward effect on the rate of employment among nativeborn and immigrants, again at the lower end of the labor market. (The Triennial Comprehensive Report on Immigration, INS 1999).

Relatively high unemployment and relatively low labor force participation: Generally, the unemployment among non-western foreigners (14\%) is very high compared to the unemployment of the native population (3\%). A same tendency is visible with respect to labor force participation; $66 \%$ of the native population participates in the labor market as opposed to $45 \%$ of the non-western foreigners. Within the unemployed group, youth, long-term unemployed, and groups with an accumulation of negative characteristics, deserve specific attention because of their relatively bad position in the labor market.

Shortages on the labor market: Currently, employers in many sectors have difficulties finding the right people for their vacancies. This holds, for example, in the sectors information technology and nursing. It is currently debated whether these shortages could be filled by labor migration.

Connection between 'inburgeringsprogramma's' and labor market has difficulties: Although many non-western foreigners have participated in integration programs, they still have difficulties finding a job. The programs do not prepare them well enough for the labor market.

Discrimination on the labor market: There is a suspicion that some employers prefer natives over non-western foreigners when they fill job vacancies.

Limited knowledge: There is little knowledge available with respect to the effects of immigration on the Dutch labor market. 


\subsubsection{GOVERNMENT POLICIES}

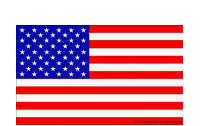

The main principle behind employment related immigration is that "immigrants should not displace native-born workers". Hence, the establishment of a labor certification process, by which an employer decides to bring in an immigrant permanently or temporarily, must show that there are no native workers available to fill the position.

Labor certification: Issued by the Department of Labor, a labor certification contains attestations by us employers as to the number of us workers available to undertake the employment sought by an applicant. It also attests to effects of the alien's employment on the wages and working conditions of us workers similarly employed. The determination of labor availability is made at the time of a visa application and at the location in which the applicant wishes to work. Again, employers seeking to hire a foreign worker must show that they have unsuccessfully attempted to recruit us workers for the job in question and that they will pay the foreign worker at least the prevailing wage for the job. To bring in someone permanently can take up to three years. The preference system outlined in the Immigration Act of 1990, is described in section 3.2.

Job training: Typically, immigrants receiving some training in the us receive it from the same programs, location, and form as native-born workers. Overall, federal government programs play a small role in the actual provision of training, mostly because these programs are targeted to disadvantaged groups and those at the lower end of the labor market.

At the national level, there is the Job Training Partnership Act (JTPA) which provides job-training services for economically disadvantaged adults and youth, dislocated workers and others who face significant employment barriers. The main objective of the act, which became effective on October 1, 1983, is to move jobless individuals into permanent self-sustaining employment. While there is no specific aim of targeting immigrants, it is likely that many fall under the category of disadvantaged.

State and local governments, together with private sector, have primary responsibility for development, management and administration of training programs under JTPA.

Immigrants can also participate in training programs targeted to welfare recipients (Work Incentive or WIN), to displaced workers (Trade Adjustments) and to veterans. Participation of immigrants in these programs is typically very low (Vernez 1999: 165). 
Immigrants and natives should have equal chances on the labor market. The objective for this cabinet is to halve the difference in unemployment between natives and ethnic minorities. Several policies are implemented to reach this objective.

Law to encourage participation of ethnic minorities in the labor market ( = Wet SAMEN; Wet Stimulering Arbeidsdeelname Minderheden): Companies with more than 35 employees are obliged to register the number of ethnic minorities among their employees. If they have than the proportional number of people from ethnic minority groups, they have to explain why this is the case and what they do to change the situation.

Law on integration of immigrants (= Wet WIN; Wet Inburgering Nieuwkomers): In addition to the obligatory courses, this law also provides support to find a job. Law on foreign labor (= WAV; Wet arbeid vreemdelingen): Employers need a license (tewerkstellingsvergunning) when they want to hire foreign labor. Based on this same law, asylum seekers are allowed to work when they have been in the Netherlands for more than 6 months (under specific conditions).

Job training: Immigrants can participate in all training programs for unemployed. They can benefit from the Law on employability for job seekers (= wIw; Wet Inschakeling Werkzoekenden). This law prepares people that have been long-termunemployed for a job in the regular labor market by offering them work experience. In addition, there are programs (instroom - doorstroombanen) to prepare long-term-unemployed for the labor market by improving their access to the labor market and make it easier for them to move on to a better job.

MOTOR-project: A project to stimulate ethnic entrepreneurship.

\subsubsection{STATISTICS}

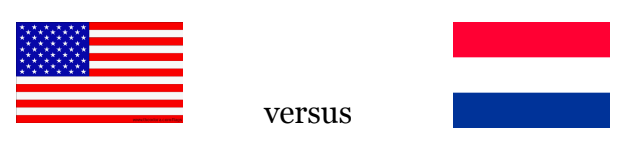

\section{Unemployment rates}

Table 4.12 NL: Unemployment rate, by ethnic group (1999)

\begin{tabular}{|l|r}
\hline Natives & $3 \%$ \\
Western foreigners & $5 \%$ \\
Non-western foreigners & $14 \%$ \\
- Turks & $13 \%$ \\
- Moroccans & $18 \%$ \\
- Surinamese & $10 \%$ \\
\hline
\end{tabular}

Source: CBS (2000: 81) 
Table 4.13 US: Unemployment rate, by racial group (1999)

\begin{tabular}{|l|c|}
\hline Total population & $4.1 \%$ \\
- White & $3.5 \%$ \\
- Black & $7.9 \%$ \\
- Hispanic & $5.9 \%$ \\
Total population & \\
- Natives (1997 data) & $5.4 \%$ \\
- Foreign-born (1997 data) & $6.9 \%$ \\
\hline \multicolumn{2}{|c|}{ Source:www.bls.gov }
\end{tabular}

\section{Labor force participation rates}

Table 4.14 NL: Labor force participation rates, by ethnic group (1999)

\begin{tabular}{|l|l}
\hline Natives & $66 \%$ \\
Western foreigners & $62 \%$ \\
Non-western foreigners & $45 \%$ \\
- Turks & $40 \%$ \\
- Moroccans & $37 \%$ \\
- Surinamese & $58 \%$ \\
- Antilleans/Arubans & $53 \%$ \\
\hline
\end{tabular}

Source: CBS (2000: 81)

Table 4.15 US: Labor force participation rate (1999)

\begin{tabular}{|l|l|}
\hline Total population & $67 \%$ \\
- Hispanics & $68 \%$ \\
\hline \multicolumn{2}{|c|}{ Source:www.bls.gov }
\end{tabular}

\section{Self-employment rates}

Table 4.16 NL: Self-employment rates by country/region of origin (1997)

\begin{tabular}{|l|r}
\hline Natives & $10 \%$ \\
Turks & $12 \%$ \\
Moroccans & $6 \%$ \\
Surinamese & $5 \%$ \\
Antilleans/Arubans & $6 \%$ \\
\hline
\end{tabular}

Source: SCP (1999: 31)

Table 4.17 US: Self-employment rates by country/region of origin (1990)

\begin{tabular}{|l|rr}
\hline & Men & Women \\
\hline Natives & $13.1 \%$ & $7.2 \%$ \\
Foreign-born & $13.1 \%$ & $8.3 \%$ \\
- Europeans & $18.4 \%$ & $10.2 \%$ \\
- Asians & $15.9 \%$ & $9.8 \%$ \\
- Mexicans & $7.2 \%$ & $5.7 \%$ \\
\hline
\end{tabular}

Source: Smith 1997: 163) 


\subsection{SOCIAL WELFARE}

Section 4.3 focuses on the access of immigrants to social welfare programs and the degree to which immigrants benefit from these programs. A relatively high use of social welfare programs is often considered to be a sign of poor integration in society. This section mainly focuses on key problems, policies, and the division of responsibilities between different levels of government.

Table 4.18 Overview of social welfare issues and policies

\begin{tabular}{|c|c|c|}
\hline & The Netherlands & United States \\
\hline Key problems & $\begin{array}{l}\text { Relatively high use of social welfare } \\
\text { programs. } \\
\text { More low-income families among } \\
\text { non-western foreigners than among } \\
\text { natives. }\end{array}$ & $\begin{array}{l}\text { Relative intense use of some wel- } \\
\text { fare programs by immigrants. } \\
\text { More low-income families among } \\
\text { non-western foreigners than among } \\
\text { natives. } \\
\text { Without a history of work in the US, } \\
\text { the immigrant parents of uS citizens } \\
\text { are not eligible to receive Social } \\
\text { Security benefits. }\end{array}$ \\
\hline General policies & $\begin{array}{l}\text { Immigrants are generally eligible for } \\
\text { public social welfare programs. } \\
\text { Koppelingswet. } \\
\text { Zorgwet WTV(VVTV = Provisional } \\
\text { Residence Permit). } \\
\text { Foreigners' law } 2000 \\
\text { (Vreemdelingenwet } 2000 \text { ) } \\
\text { Local governments sometimes offer } \\
\text { specific benefits to low income } \\
\text { groups. }\end{array}$ & $\begin{array}{l}\text { Immigrants are to some extent } \\
\text { eligible for public social welfare } \\
\text { programs. } \\
\text { PRWORA August 22, } 1996 \text { (= Per- } \\
\text { sonal Responsibility and Accounta- } \\
\text { bility Act, often referred to as the } \\
\text { federal welfare reform law). } \\
\text { BBA } 1997 \text { (= Balanced Budget Act) } \\
\text { contains several provision affecting } \\
\text { non-citizens in Supplemental Se- } \\
\text { curity Income program. } \\
\text { Agricultural Research Reform Act } \\
\text { (February } 11,1998 \text { ). } \\
\text { In addition to federal programs, } \\
\text { states supply additional welfare } \\
\text { programs. } \\
\text { The states are given little flexibility } \\
\text { in serving illegal immigrants. }\end{array}$ \\
\hline Division of resp & $\begin{array}{l}\text { ties } \\
\text { Major decisions with respect to } \\
\text { social welfare are taken at a national } \\
\text { level. }\end{array}$ & $\begin{array}{l}\text { PRWORA } 1996 \text { increased state control } \\
\text { over much of the nation's welfare } \\
\text { system from the federal govern- } \\
\text { ment to the individual states. States } \\
\text { have some discretion in deciding } \\
\text { about social welfare programs. }\end{array}$ \\
\hline Statistics & $\begin{array}{l}\text { Natives ( } 9 \%) \text { rely much less on } \\
\text { social welfare than all studied groups } \\
\text { of non-western foreigners. } \\
\text { Among the native population (14\%) } \\
\text { much fewer households belong to } \\
\text { the low-income households than } \\
\text { among the non-western foreign } \\
\text { households }(43 \%) \text {. }\end{array}$ & $\begin{array}{l}\text { Natives benefit less from means- } \\
\text { tested cash and non-cash benefits } \\
\text { than most groups of non-western } \\
\text { foreigners. } \\
\text { Non US citizens are more often } \\
\text { living below the poverty line ( } 28 \%) \\
\text { than US citizens (14\%). }\end{array}$ \\
\hline
\end{tabular}




\begin{tabular}{|c|c|c|}
\hline & The Netherlands & United States \\
\hline Statistics & $\begin{array}{l}\text { The whole population is covered by } \\
\text { some kind of health insurance. } \\
\text { Natives }(23 \%) \text { receive less regularly } \\
\text { rent assistance than the largest } \\
\text { groups of non-western foreigners in } \\
\text { the Netherlands. }\end{array}$ & $\begin{array}{l}\text { Of the native population } 86 \% \text { is } \\
\text { covered by a health insurance as } \\
\text { opposed to } 66 \% \text { of the foreign-born } \\
\text { population. } \\
\text { Refugees more often benefit from } \\
\text { housing support programs than } \\
\text { natives and non-refugees. }\end{array}$ \\
\hline
\end{tabular}

\subsubsection{KEY ISSUES}

The key issue is the use of social welfare programs by immigrants. Nonetheless, this concern is mostly present during times of economic recession. At present, with a growing economy, this is no longer an issue. Data show that immigrants use some welfare programs relatively intensely: bilingual education, Supplemental Security Income (SSI), public assistance and Medicaid. However, other programs are relatively little used: Social Security and Medicare.

Without a history of work in the Us, the immigrant parents of us citizens are not eligible to receive Social Security benefits. SsI becomes an alternative source of income for some elderly people with few other resources.

Relatively high use of social welfare programs: Non-western foreigners make relatively intense use of social welfare programs, such as unemployment benefits (WW), welfare (ABW), and disability benefits (WAO). A relatively large proportion of the immigrants population are dependent upon public benefits.

More low income families among non-western foreigners than among natives: Non-western foreigners belong more often to the group of low income families than natives, which is of course partly a consequence of their high dependence upon public benefits.

\subsubsection{GOVERNMENT POLICIES}

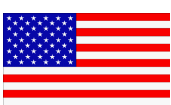

A main guiding principle is that immigrants should not be likely to become 'public charges' and to discourage immigrants to come to the us for the welfare benefits it offers. 


\section{Federal social welfare arrangements}

President Clinton signed The Personal Responsibility and Accountability Act (PRWORA) of 1996 (Welfare Act) on 22 August 1996. It transferred control of much of the nation's welfare system from the Federal Government to the individual states. It also imposed several new restrictions on aid to legal immigrants.

PRWORA institutionalized the concept of immigrant exceptionalism - treating noncitizens differently from similarly situated citizens - to a new and unprecedented degree in Us social welfare policy. PRWORA restricted access to and use of public assistance programs for legal immigrants who are not citizens, during the first 5 years of residence in the Us. It also bars non-citizen immigrants who have been in the us for more than 5 years from some general welfare programs. After 5 years, coverage of non-citizens is at the discretion of the states and after 5 years noncitizens can naturalize and be eligible for assistance. Finally, it sets a lifetime limit of 5 years on the use of public assistance by any individual (not only immigrants). The law entailed an unprecedented federal devolution of authority to states to determine immigrants' access to public assistance.

In some instances, the states have followed the Congress's lead by imposing new types of restrictions on immigrants' access to benefits. In other instances, however, states created new substitute programs for immigrants. In addition, some federal laws were enacted to restore eligibility of specific groups for specific social welfare programs. The Balanced Budget Act of 1997 (вВА) contained several provisions affecting non-citizens in the Supplemental Security Income program. Serving to ease some of the restrictions imposed by PRWORA in 1996, the new law expanded the categories of aliens who may be eligible for SsI while extending the timeframes for receiving ssI for certain aliens subject to time-limited benefits. In addition, the Agricultural Research Reform Act 1998 partially restored eligibility to legal aliens benefits that had been restricted by PRWORA. The main provision is a continued eligibility to receive Food Stamps for qualified aliens 65 or over by 22 August 1996, subsequently disabled, and/or while under 18.

However, overall the social safety net remains weaker than before the 1996 welfare reform and non-citizens have generally less access to assistance than citizens (Zimmerman 1999: 5). The table below describes the eligibility of non-citizens to means-tested social welfare programs.

The devolution of authority to states to determine immigrants' access to public assistance, led to increased inequality across state immigrant safety nets. The states with the strongest existing safety nets (such as California) made the most generous decisions for immigrants. The states making the fewest efforts to replace benefits tend to be the states with the weakest safety nets (such as Texas). The increased variation across state safety nets raises interesting questions, such as "Will the patterns of state decisions lead to interstate migration, with more immigrants moving to California and other states with more generous safety 
nets?" (Zimmerman 1999: 49). The answers to these questions for the 1996 welfare reform are not yet known. However, the effect of differential coverage and/or level of benefits on interstate migration patterns has been addressed in past research.

This research showed no effect.

Table 4.19 US: Non-citizen eligibility3 for means-tested social welfare programs

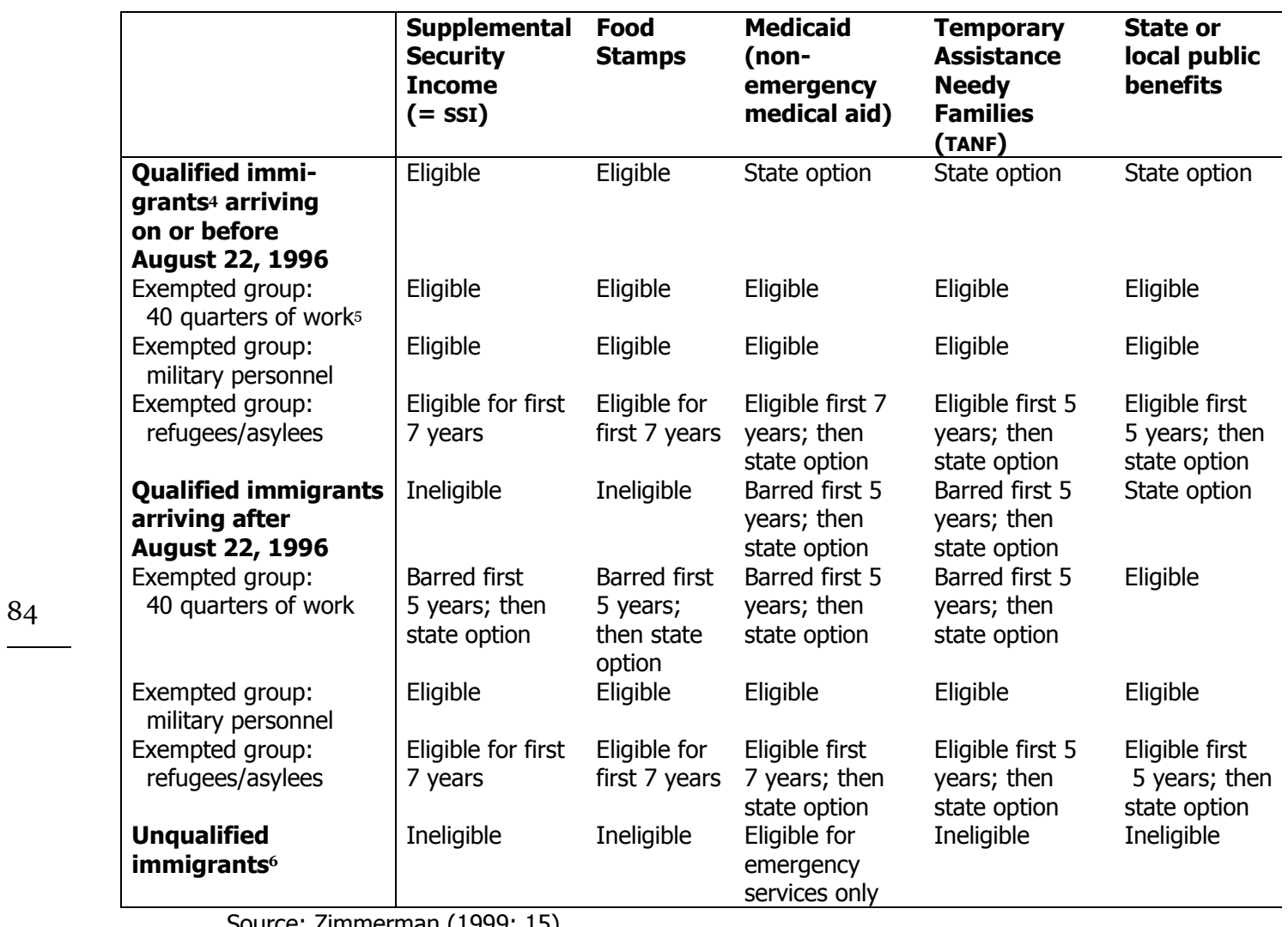

Source: Zimmerman (1999: 15)

\section{State social welfare arrangements : the California case}

Despite its anti-immigrant reputation, California provides substantial benefits to its qualified immigrant population. It is one of the most generous states in providing assistance to qualified immigrants. At the same time, it is most aggressive in trying to bar the unqualified from state public benefits. While a few other states have restricted unqualified immigrants from state assistance, none has cast its net as widely as California.

California has a recent history of restricting public benefits for undocumented immigrants. At least 20 California state agencies have now issued regulations barring unqualified immigrants from various federal and state benefits and state-issued professional licenses, such as assistance provided by the Department of Housing and Urban Development, and the issuance of commercial driver's licenses. These 
regulations had not been implemented as of September 1998, however, primarily because of successful court challenges and the state legislature's refusal to authorize funding for state agencies to pay for verification systems.

This divided approach reflects the unique politics of immigration in California, where increasing numbers of immigrants are naturalizing in order to vote and immigrant advocacy organizations are growing in size (Zimmerman 1999: 40).

\section{Table 4.20 California: Non-citizen benefit eligibility for social welfare programs}

\begin{tabular}{|l|l}
\hline Cash assistance & YES \\
TANF to pre-enactment immigrants7 & YES \\
State-funded TANF during the five-year bar & YES \\
- Sponsor-deeming8 & YES \\
Provision of TANF following the five-year bar & YES \\
SSI substitute for immigrants & Pre- and certain post-enactment \\
- Eligible group(s) & immigrants \\
& NO \\
- Sponsor-deeming & YES \\
General assistance or similar cash program & All qualified immigrants \\
- Immigrant eligibility & \\
Food assistance & YES \\
State-funded food program for immigrants & Pre- and certain post-enactment \\
- Eligible group(s) & immigrants \\
- Sponsor-deeming & YES \\
Health care & \\
Medicaid to pre-enactment immigrants & YES \\
State-funded Medicaid during the five-year bar & YES \\
- Sponsor-deeming & NO \\
Provision of Medicaid following the five-year bar & YES \\
Provision of Medicaid to certain unqualified immigrants & YES \\
Medicaid generosity level (scale 1-8) & 4 \\
State health insurance program & YES \\
- Immigrant Eligibility & All qualified immigrants \\
Naturalization initiative & YES \\
\hline
\end{tabular}
Source: Tumlin (1999: 13)

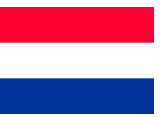

Immigrants are generally eligible for public social welfare programs. With respect to access to these programs, different criteria apply to different types of immigrants (see table below). This is regulated in different laws.

Koppelingswet: Foreigners that have not (yet) been admitted to the Netherlands do not have a right to welfare services, except for education, necessary medical care, and legal aid. The aim of the Koppelingswet was to discourage illegal stay in the Netherlands.

Zorgwet VVTV (VVTV = Provisional Residence Permit): Local governments receive a lump-sum payment for each VVTV-statushouder in their community. From this 
money, they provide an income, housing, health insurance, a liability insurance, and possibly extraordinary costs.

Vreemdelingenwet 2000 (Foreigners' law 2000): This law will change access to services. For people with an A-status or VTV-status, the situation hardly changes. People holding a VVTV-status will get the same right as the first groups; they will have access to, e.g., Algemene Bijstandswet (ABW), health insurance, individual rent assistance, etc. All holders of a status have access to student grants.

Local governments sometimes offer specific benefits to low income groups: Lowincome groups generally include a substantial proportion of the immigrant population. Examples of benefits provided by local government are exemption from local fees and reduced prices for specific local services (such as subscriptions to a library, swimming pool, etc.).

Table 4.21 NL: Access to the Dutch social welfare system (and related public benefits) for specific groups of immigrants

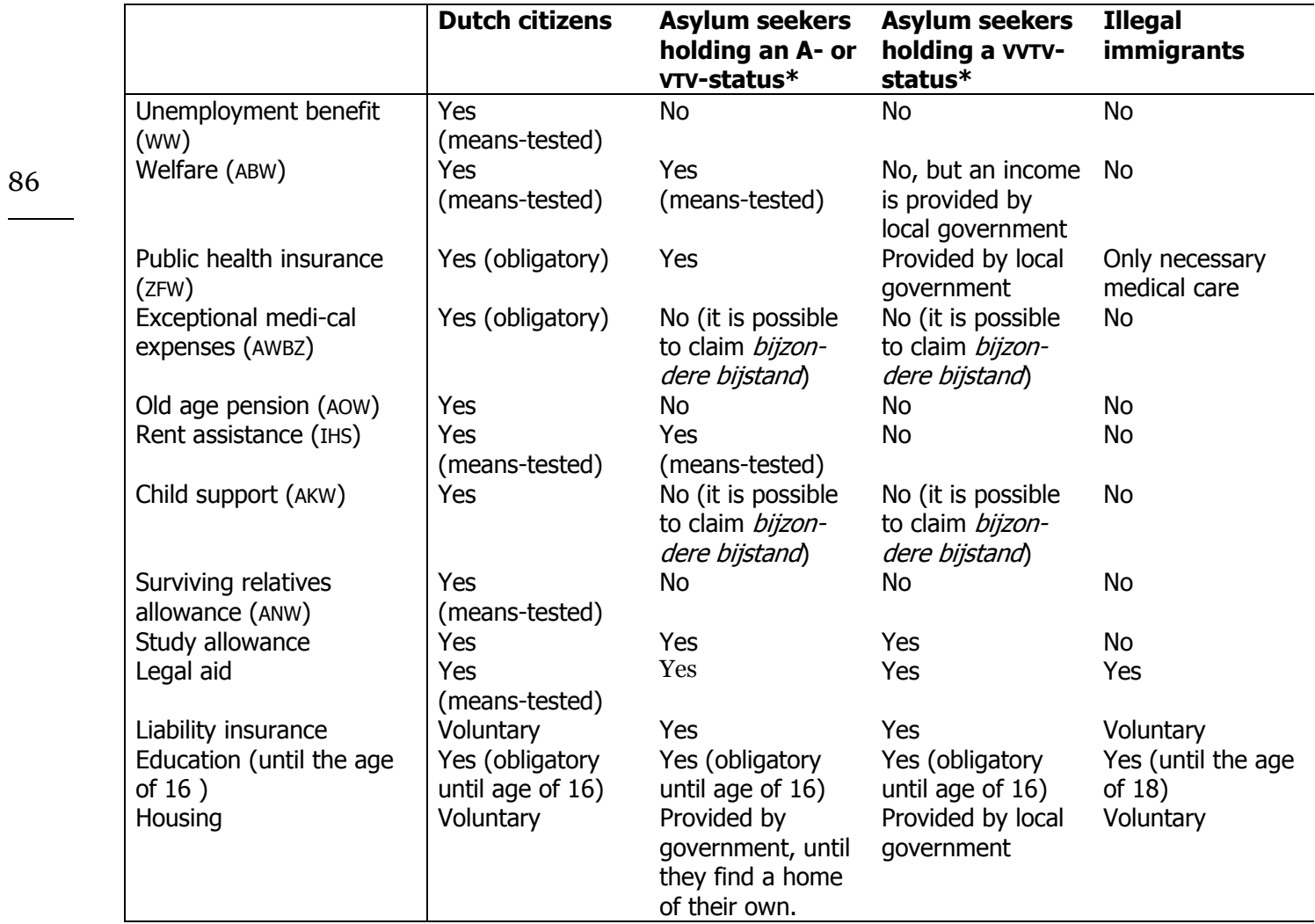

* After the introduction of the Foreigners' Law 2000, the difference between A-, VTV-, and VVTV-status will disappear. The people who currently have a VVTV-status will then get the same benefits as holders of an A- or VTV-status are currently receiving. Another change is that people with a status will be eligible for AWBZ. 


\subsubsection{STATISTICS}

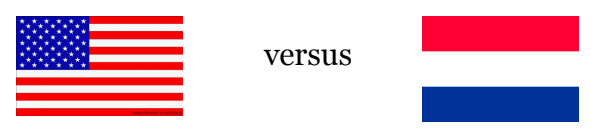

Main sources of income

Table 4.22 NL: Main sources of income

\begin{tabular}{|l|rrr}
\hline & Labor & Allowances* & Other \\
\hline Turks & $58 \%$ & $33 \%$ & $9 \%$ \\
Moroccans & $51 \%$ & $35 \%$ & $14 \%$ \\
Surinamese & $70 \%$ & $21 \%$ & $9 \%$ \\
Antilleans/ Arubans & $62 \%$ & $25 \%$ & $12 \%$ \\
Afghans & $15 \%$ & $68 \%$ & $17 \%$ \\
Iranese & $39 \%$ & $48 \%$ & $14 \%$ \\
Somalis & $32 \%$ & $51 \%$ & $16 \%$ \\
Ethiopians & $60 \%$ & $21 \%$ & $19 \%$ \\
Natives & $68 \%$ & $9 \%$ & $23 \%$ \\
\hline \multicolumn{2}{c|}{ Source: ISEO (2000: 68-69) } & & \\
\end{tabular}

Table 4.23 US: Households receiving selected means-tested non-cash or cash benefits (1996)

\begin{tabular}{|l|rr}
\hline & Selected non-cash benefits & Selected cash benefits \\
\hline Natives & $17 \%$ & $7.5 \%$ \\
Foreign-born & $24.1 \%$ & $10.6 \%$ \\
- Europeans & $13.9 \%$ & $6.4 \%$ \\
- Asians & $17.5 \%$ & $7.9 \%$ \\
- Africans & $25.5 \%$ & $11.7 \%$ \\
- Latin Americans & $32.9 \%$ & $14.1 \%$ \\
- Southern Americans & $21.4 \%$ & $9.0 \%$ \\
- Northern Americans & $15.6 \%$ & $5.3 \%$ \\
\hline
\end{tabular}

Source: Current Population Reports, Special Studies pp. 23-195

\section{Health insurance coverage}

NL: Close to $100 \%$ for all groups

Table 4.24 US: Households receiving selected means-tested non-cash or cash benefits (1996)

\begin{tabular}{|l|l|}
\hline Natives & $86.3 \%$ \\
Foreign-born population & $66.4 \%$ \\
\hline
\end{tabular}

Source: Current Population Reports, Special Studies pp. 23-195 


\section{Low income households}

Table 4.25 NL: Households with a low income, by country of origin (1996)

\begin{tabular}{|l|r}
\hline & Low-income households \\
\hline Natives & $14 \%$ \\
Non-western foreigners & $43 \%$ \\
- Turks & $41 \%$ \\
- Moroccans & $49 \%$ \\
- Surinamese & $37 \%$ \\
- Antilleans/Arubans & $41 \%$ \\
- Vluchtelingenlanden* & $61 \%$ \\
Former Yugoslavians & $48 \%$ \\
Southern Europeans & $20 \%$ \\
\hline
\end{tabular}

* Iran, Iraq, Somalia, Ghana, Ethiopia, Vietnam,Sri Lanka and Afghanistan Source: ISEO (2000: 73)

Table 4.26 US: Population below poverty level (1996)

\begin{tabular}{|l|r}
\hline Citizens US & $13.7 \%$ \\
Non-citizens US & $27.7 \%$ \\
Non-citizens California & $31 \%$ \\
\hline
\end{tabular}

Source: Zimmerman (2000: 58)

\section{Rent assistance}

Table 4.27 NL: Percentage of people receiving rent assistance, by ethnic group (?)

\begin{tabular}{|l|l}
\hline Natives & $23 \%$ \\
Turks and Moroccans & $37 \%$ \\
Surinamese and Antilleans & $34 \%$ \\
Southern Europeans & $20 \%$ \\
\hline \multicolumn{2}{|c|}{ Source: WPRB (2000: 234) }
\end{tabular}

Table 4.28 US: Participation in housing support programs (1990-1993)

\begin{tabular}{|l|rrr}
\hline & Public assistance & Rent assistance & Energy assistance \\
\hline Natives & $1.3 \%$ & $2.1 \%$ & $1.1 \%$ \\
Foreign-born population & $1.8 \%$ & $2.5 \%$ & $1.1 \%$ \\
- Refugees & $4.9 \%$ & $4.5 \%$ & $3.2 \%$ \\
- Non-refugees & $1.6 \%$ & $2.3 \%$ & $0.9 \%$ \\
\hline
\end{tabular}

Source: Survey of Income and Program Participation of the Bureau of the Census, in Vernez (1999)

\subsection{HOUSING}

This section focuses on housing of immigrants, and especially on the housing situation of non-western foreigners. The housing situation for non-western foreigners is different from the housing situation for Dutch citizens and western foreigners, and therefore deserves special attention. However, it needs to be stressed that we should not confuse problems related to housing of non-western foreigners with the housing problems of disadvantaged groups (such as African Americans) in general. 
Table 4.29 Overview of housing issues and policies

\begin{tabular}{|c|c|c|}
\hline & The Netherlands & United States \\
\hline Key problems & $\begin{array}{l}\text { Geographic concentration in housing } \\
\text { of non-western foreigners. } \\
\text { Homeownership rate for non- } \\
\text { western foreigners is relatively low. } \\
\text { Long waiting lists for housing for } \\
\text { asylees; shortage of available places. } \\
\text { Difficulties finding housing for single } \\
\text { asylees. }\end{array}$ & $\begin{array}{l}\text { Clustering pattern in many uS cities. } \\
\text { Homeownership rate for non- } \\
\text { western foreigners is relatively low. }\end{array}$ \\
\hline Foreigner specifi & $\begin{array}{l}\text { Housing Law (Huisvestingswet) and } \\
\text { Zorgwet VVTV } \\
\text { Foreigner's law } 2000 \text { will make } \\
\text { housing available to all people with } \\
\text { an A-, VTV- or VVTV-status. Currently, } \\
\text { free choice of housing is not avail- } \\
\text { able for VVTV-holders. } \\
\text { Some local governments have } \\
\text { specific programs providing housing } \\
\text { to specific ethnic groups. }\end{array}$ & $\begin{array}{l}\text { No government policies; some } \\
\text { private initiatives, such as refugee } \\
\text { resettlement programs by Catholic } \\
\text { Social Services. }\end{array}$ \\
\hline General policies & $\begin{array}{l}\text { In general, rule of the market. } \\
\text { However, incentives are given to } \\
\text { avoid too homogeneous neighbor- } \\
\text { hoods. } \\
\text { Rent assistance. }\end{array}$ & $\begin{array}{l}\text { Rule of the market. However, in- } \\
\text { centives are given to avoid too } \\
\text { homogeneous neighborhoods. } \\
\text { Public housing assistance, rent } \\
\text { assistance, and energy assistance. }\end{array}$ \\
\hline Statistics & $\begin{array}{l}\text { Segregation in big cities; the index } \\
\text { of dissimilarity is highest in The } \\
\text { Hague. } \\
\text { Natives ( } 54 \% \text { ) more often own a } \\
\text { house than non-western foreigners } \\
(19 \%) \text {. }\end{array}$ & $\begin{array}{l}\text { Segregation in big cities in } \\
\text { California; the index of dissimilarity } \\
\text { is highest in Los Angeles } \\
\text { Natives ( } 68 \%) \text { more often own a } \\
\text { house than foreign-born households } \\
(47 \%) \text {. }\end{array}$ \\
\hline
\end{tabular}

\subsubsection{KEY ISSUES}

Segregation: Segregation is the physical separation of members of one racial, ethnic, social, or economic group from members of another group. The us data mostly measure the separation of black from non-blacks, and of Hispanics from non-Hispanics. No single measure can fully characterize segregation. However, several indices attempt to capture important aspects. An often-used one, is the Index of Dissimilarity which measures the extent to which specific groups are concentrated within specific parts of cities. It ranges between zero and one, and can be interpreted as the fraction of, e.g. blacks (Us) or ethnic minorities (Netherlands), that would have to switch areas to achieve an even racial distribution citywide. Zero indicates perfect integration, and one perfect segregation. A value above 0.6 is 
generally considered to be high (www.pubpol.duke.edu). For data on the Californian indexes of dissimilarity, see the statistics section.

The people living in ghettos are typically black and poor, many are on welfare, and even those who work tend to receive salaries that place them beneath the poverty line. In the last 30 years, the number of blacks financially able to leave the ghettos increased significantly, thanks to, among others, general growth of the economy and to a number of civil rights strategies. Although moving out of the ghetto presumably improved the quality of life of those who moved, it had an unfortunate effect on the economic and social profile of the community they left. It turned the black ghetto into a community of the most disadvantaged. The contemporary urban ghetto can be seen as the home of the black underclass, a class that suffers from a multitude of disadvantages - above all, joblessness and poverty - that relegate its members into the lowest stratum in society and lock them into it. The concentration of this social group in one relatively compact geographic area intensifies both the deprivation and the barriers to upward mobility.

It has to be stressed that segregation is not considered to be an immigrationrelated issue.

Segregation: Most non-western foreigners live in the four big cities, and especially within specific parts of these cities. For data on the Dutch indexes of dissimilarity, see the statistics section.

Homeownership rate for non-western foreigners is relatively low: The home ownership rate for natives $(54 \%)$ is much higher than the rate for non-western foreigners (19\%).

Waiting lists for housing for asylees: There are waiting lists for housing for asylees, especially housing for single asylees. This shortage is mainly caused by a shortage of available places.

\subsubsection{GOVERNMENT POLICIES}

Segregation: In the housing arena, the guiding principle is the rule of the market (supply and demand). However, incentives are given too avoid too homogeneous neighborhoods:

- The most promising remedies are those that seek to deal with the spatial mismatch between workers and jobs, i.e. the fact that jobs have moved to the suburbs while the workers remained in the inner city. An example of such a reme- 
dy, is the creation of 'enterprise zones' and 'empowerment zones' in the inner city, which provide economic incentives for businesses to relocate or simply remain there. The overall goal of these programs is to transform a poverty community into a mixed-income community.

- Civil rights strategies.

- Other related policies are the enlargement of educational opportunities for blacks (by offering them access to some of the better elementary and seconddary schools), and the 1996 welfare reforms that were designed to create incentives or pressure for welfare recipients to find work.

Housing assistance: Specific programs include public housing assistance, rent assistance, and energy assistance. Data from 1990-93 (pre-PRWORA) suggest a low immigrant participation rate in these programs. Highest percentage participation corresponded to refugees (see statistics).

Geographic spread: In general, the market rules. However, the government implements policies to avoid too homogeneous neighborhoods. Policies are, for example, investments in disadvantaged areas and 'diverse building', i.e. mixing of cheap and expensive houses in one neighborhood.

When asylum seekers enter the Netherlands, they are assigned to a reception center. After being granted an A- or vTV- status, they are offered a house. However, if they do not want that house they are free to settle wherever they wish.

Housing Law (Huisvestingswet) and Zorgwet VVTV: The first three months, asylum seekers are accommodated in 'reception and investigation centers'. Thereafter they move to asylum seekers' residence centers. There are specific policies to shorten the waiting lists and reduce the shortage of available places. Asylum seekers that have been in NL for $>6$ months, are allowed to stay with relatives or friends. After admission, they are offered a house, but they are free to settle wherever they wish.

Foreigner's law 2000: This new law, to be implemented in 2001, will make housing available to all asylum seekers with an A-, VTV-, or VVTV- status. Currently, free choice of housing is not available for asylum seekers with a VTVV-status.

Rent assistance: Low-income families have a right to rent assistance. Legal immigrants are also eligible for this program.

Specific local government programs: Some local governments have specific programs providing housing to specific ethnic groups, e.g. the city of Almelo has a specific program to develop and improve housing for elderly Turks. 


\subsubsection{STATISTICS}

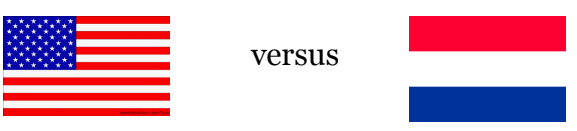

\section{Homeownership rate}

Table 4.30 NL: Homeownership rate (1999)

\begin{tabular}{|l|r|}
\hline Natives & $54 \%$ \\
Western foreigners & $47 \%$ \\
Non-western foreigners & $19 \%$ \\
- Turks & $15 \%$ \\
- Moroccans & $3 \%$ \\
- Surinamese + Antilleans & $24 \%$ \\
- Other & $24 \%$ \\
\hline \multicolumn{2}{|c|}{ Source: CBS (2000: 99) }
\end{tabular}

Table 4.31 US: Homeownership rate (1997)

\begin{tabular}{|l|l|}
\hline Native householders & $67.8 \%$ \\
Naturalized householders & $65.7 \%$ \\
Foreign-born householders & $47.1 \%$ \\
- Europeans & $62.6 \%$ \\
- Africans & $33.2 \%$ \\
- Asians & $50.5 \%$ \\
- Latin Americans & $38.0 \%$ \\
- Southern Americans & $41.5 \%$ \\
- Northern Americans & $63.3 \%$ \\
\hline
\end{tabular}

Source: Current Population Reports, Special Studies

\section{Dissimilarity index}

Table 4.32 NL: Index of dissimilarity (1999)

\begin{tabular}{|l|l}
\hline Rotterdam & 0,35 \\
The Hague & 0,44 \\
Amsterdam & 0,30 \\
Utrecht & 0,25 \\
Helmond & 0,33 \\
Enschede & 0,14 \\
\hline
\end{tabular}

Source: ISEO (2000: 130)

Table 4.33 US: Index of dissimilarity (1990; blacks versus non-blacks)

\begin{tabular}{|l|r}
\hline Los Angeles & 0,64 \\
San Francisco & 0,58 \\
San Diego & 0,50 \\
San Jose & 0,32 \\
Santa Cruz & 0,43 \\
\hline
\end{tabular}

Source: www.pubpol.duke.edu 


\subsection{BILATERAL COMPARISON OF INTEGRATION RELATED ISSUES}

\subsubsection{EDUCATION}

There are many similarities between the issues with respect to Dutch and American education. Although sometimes there are subtle differences in the focus of the discussion, many of the issues discussed in the Netherlands are also discussed in the us. The main issues in both countries are relatively low participation of specific ethnic groups in high education (although which groups are problematic differ between countries), high dropout percentages, language problems, too large classes, young children with a disadvantaged position, and 'black schools'. 9 In the Netherlands, the shortage of teachers is considered to be a major problem. In the Us, shortage of teachers is also considered to be a problem. The shortage of teachers partly results from policies aimed at reducing class size and raises issues about the quality of the teachers.

In the Netherlands and the Us, similar approaches are also chosen to address the identified issues. In both countries, language courses are considered to be important (in the Netherlands they are even compulsory for some types of immigrants) and speaking the language of the new home country is considered to be a prerequisite for successful integration. However, the expenditures on language courses do not match the high priorities assigned to them. In the us, for example, the English as a Second Language programs are woefully underfunded relative to demand. Further, many similar programs are implemented to improve school performance of children of immigrants. Finally, both countries allow children of immigrants and impose barriers with respect to access to higher education.

\subsubsection{EMPLOYMENT}

The Dutch and American issues and policies with respect to the labor market have some similarities, but also differences. The major differences are described below.

In the Netherlands, there are big differences between natives and non-western foreigners in employment and labor force participation rates. These differences continue to exist despite several policies focused on encouraging non-western foreigners to participate in the labor market. In the Us, however, natives and non-western foreigners have approximately equal employment and labor force participation rates, and there are only few policies that are specifically focusing on immigrants. It is hard to explain these differences between the us and the Netherlands, because many variables play a role. Possible explanatory variables are differences in educational background of the immigrants, differences in functioning of the us and the Dutch labor market, the relative lack of social welfare arrangements in the US, etc. 
In the Netherlands, labor migration formed a very substantial of total immigration in the sixties, when Turks and Moroccans migrated to the Netherlands and filled job vacancies for low-skilled jobs. Since then, labor migration has been on a lower level. However, currently the issue of labor migration gets renewed attention, because of shortages in the labor market, notably for low-skilled, but also for highskilled jobs. The us in general, and California specifically, have been faced with a continuous influx of labor migrants in both high-skilled and low-skilled jobs.

The effects of immigration flows on the us labor market have been seriously studied. In the Netherlands, only limited knowledge on the labor market effects of immigration is available. Such studies would be valuable to improve future decision-making on labor migration. [However, it should not be forgotten that, in addition to economic factors, social and humanitarian values play a role in decision-making about labor migration].

\subsubsection{SOCIAL WELFARE}

The us and the Netherlands have more or less similar problems with respect to social welfare. In both countries, the use of social welfare programs by specific groups of immigrants is relatively high. However, in the us this is currently not considered to be a problem. The use of public services by immigrants was one of the main reasons for PRWORA. The high use of public services is not an issue at the moment, because it is considered fixed for now. The rosy economic picture is a second factor and the reason why the federal government and the states have restored eligibility for some services. In the Netherlands, the relative high use of social welfare programs is currently considered to be problematic and is regularly discussed in the media. In both the us and the Netherlands, the poverty among immigrants is relatively high. Because different definitions are used to define poverty, it is difficult to figure out whether poverty is relatively larger among US immigrants than among immigrants to the Netherlands.

Although a wide range of social welfare programs exists in both the Netherlands and the Us, the benefit levels of these programs vary between the two countries. For example, in the Netherlands net welfare benefits equal NLG 2317,91 (ca. USD 1000,-) for couples, NLG 1622,54 (ca. USD 675,-) for single parents, and NLG 1158,96 (ca. USD 485,-) for singles. The most comparable program in the US, Temporary Assistance to Needy Families (TANF), offers a benefit level of USD 565,in California for a family of three. The us benefit levels vary between states. In Alaska, for example, TANF benefits are USD 923,- and in Kentucky USD 262,-TANF benefits are provided for a maximum of 60 months in a lifetime. In general, it can be concluded that the welfare benefits in the us are lower than the benefits in the Netherlands, and that they are offered for a shorter period of time. The Netherlands has a far more generous welfare policy than the us and, consequently, in the Netherlands many more immigrants are fully dependent on public benefits than in 
the Us. This raises questions with respect to the accessibility and maintainability of social welfare programs in the Netherlands.

In the Netherlands, the primary responsibility for social welfare lies with the national government. In the us, however, authority for decision-making on social welfare has been devolved the states since 1996; the states determine immigrants' assistance to citizens. As said, this led to inequality across state immigrant safety nets, which raises interesting questions, such as "Will the patterns of state decisions lead to interstate migration, with more immigrants moving to California and other states with more generous safety nets?" Since the devolution of authority took place fairly recently, it is not yet possible to answer these questions. However, it would be very interesting and valuable to monitor the effect of variation across state safety nets, especially when thinking about European integration. The ongoing integration of the European Union makes it necessary to consider what social welfare programs to offer to immigrants, and the degree to which variation between member states is acceptable.

\subsubsection{HOUSING}

In the us very little is done with respect to housing; the market rules. There are some rent assistance programs, but very few people benefit from these programs. In the Netherlands, many more people (including immigrants) benefit from rent assistance programs. In addition, the Netherlands has a wide range of policies with respect to housing for asylum seekers. This is unknown in the Us. Finally, both the us and the Netherlands implement policies to stimulate geographical spread of low-income groups across cities. It is important to stress that the issue of segregation focuses on African Americans and not on immigrants. Black neighborhoods are not considered to be an immigration-related problem. 


\section{NOTES}

1 1,9-students are foreign students with relatively low educated parents. These students are called 1.9-students because schools get an additional payment of 0.9 of the capitation payment per student that fits into this category.

2 California's system still allows parents the option of placing a child in a bilingual program.

3 The eligibility rules alone do not guarantee that immigrants receive the assistance for which they qualify. Recent studies of immigrants' use of public benefits indicate that many citizens are not seeking the assistance for which they are eligible (Zimmerman 1999: 6).

4 Qualified immigrants are: (a) immigrants who are lawful permanent residents; (b) refugees/asylees; (c) persons paroled into the us for at least one year; and (d) battered spouses and children (with a pending or approved spousal visa or a petition for relief under the Violence Against Women Act).

5 Lawful permanent residents who have worked at least 40 qualifying quarters as defined by the Social Security Act are exempt from certain bars on immigrant's eligibility.

6 Unqualified immigrants are immigrants not falling within the qualified immigrants group (such as undocumented immigrants, asylum applicants, etc.).

7 Pre-enactment immigrants are immigrants admitted to the us on or before August 22, 1996, the date federal welfare reform was enacted.

8 Sponsor deeming is the attribution of the income and resources of an immigrant's sponsor(s) - the person who signs a legally enforceable affidavit of support - to the immigrant for purposes of determining eligibility for public benefits.

9 Although the term has very different meanings in the two countries. 


\section{FINDINGS}

\section{Three populations of immigrants $=$ three flavors of policy}

The objective of the present project was to compare the immigration and integration policies of the Netherlands and the us. A first finding of our review of the information is that there is no 'policy' for newcomers to either country. Instead, there are different, sometimes overlapping, policies for addressing three separate populations of people who desire to relocate to a new country: 'regular' legal immigrants (largely people who come for reasons of seeking employment or reunification with families), refugees and asylees (people who are fleeing dangerous situations in their home countries), and illegal immigrants (people who, for whatever reason, illegally enter the country or stay beyond their period of admission). Because these populations are treated differently in both the Netherlands and the us, and because they are very different proportions of the immigrant flows in the two countries, overall statistics based upon whether or not people are foreign-born or of foreign citizenship can be deceiving. In particular, asylees and refugees number proportionally far more in the Netherlands than in the US, and it is this category that often presents the greatest need for integration. Perhaps in response, the Dutch have developed a far more elaborated integration set of policies and programs than the Americans.

Put another way, a magic bullet for best immigration and integration practices cannot be derived from a comparison between the us and the Netherlands. Al-

hough we compared both countries on a wide range of aspects, large differences in the context generally make it inadvisable - even if it were possible - to copy policies of one country into the other. It is very hard to forecast what would happen if a us policy were implemented in the Netherlands. What would, for example, happen if the standard of the Dutch social welfare system were lowered to the American level: would the number of immigrants go down, would labor market participation go up, would the number of illegal immigrants grow?

In the remainder of this final chapter, we will first make a small number of general observations and then separately compare Dutch and American policies and practices of immigration and integration for regular immigrants, asylees and refugees, and illegal immigrants. Then, we will close with a discussion of what lessons can be learned from our comparison, to some extent in terms of policy, but more in terms of what information must be gathered in order to better inform policy.

\section{American and Dutch approaches towards immigration and integration}

With the strong caveat stated immediately above in mind, there are a few overall generalizations that are useful to mention. One difference between the two countries is in the underlying attitude towards citizenship. Americans view their country as the land of opportunity, and immigrants who wish to better their lives are welcomed to compete against both natives and other immigrants alike in taking advantage of the opportunities offered. us citizenship is viewed as a privilege and 
as conferring a superior status on an individual. This does not, however, mean that Americans have an attitude of exclusivity; overall, the us seems to be more receptive to immigrants than the Netherlands. The fact that the us has traditionally been a nation of immigrants, and that almost everyone has grandparents or greatgrandparents who were immigrants may not be unrelated to that observation. One implication of this difference, especially in the light of the increasing unification of European countries, is that the Dutch might consider easing somewhat the restrictions on obtaining Dutch citizenship in order to better compete in obtaining immigrants who can add value to Dutch society. A concrete example of this is the question of dual citizenship. The us, confident in the value of American citizenship, permits immigrants to retain their previous nationalities, while the Dutch do not. In this light, the benefits of not permitting dual nationality are open to question and might be a policy worth reconsidering.

In the Us, immigration policy is entirely governed at the federal level; the individual states have no control over the number of immigrants (either foreign or from other states) entering their territory. With respect to integration, the us federal government designs some of the policies and funds others, especially regarding asylees and refugees. But the bulk of activity and funding occurs at the state or lower level; individual states can and do have very different policies with respect to major integration issues such as bilingual education, provision of various assistance benefits, and access to higher education. 'Welfare shopping' for social benefits is a concern among the states that goes well beyond immigrants, but could dictate what state they choose to settle in. By contrast, in the Netherlands the policies on both immigration and integration are designed at a national level and are pretty much consistent throughout the country. Even when specific programs are implemented at the provincial or municipal level, the source of the funding is likely to be national. However, with growing European unification, there is discussion about some of the immigration policies moving up to a supranational policy level. The American experience urges caution here - separation of authority for immigration and responsibility for integration can yield discontinuities in policy that do not serve newcomers well.

The American attitude towards welfare is different from the Dutch and leads to differences in integration. Welfare in the us is widely regarded (at least in the ideal) as a fall-back position for people who have failed to compete successfully for the opportunities offered them (preferably through no fault of their own), and is not offered readily to newcomers, who have almost by definition not yet attempted to enter the competition. Hence, in the us, welfare that might help (re)integrate citizens is not available to recent immigrants. In the Netherlands, on the other hand, admission as a resident to the country carries the implication that the newcomer is now part of Dutch society, and therefore entitled to the full set of benefits all members of society may obtain. This includes programs that are targeted to special needs (e.g., language training, more intensive education, assistance in housing or job seeking) that help integrate foreigner and citizen alike. Our exami- 
nation of American vs. Dutch statistics on some measures of integration (e.g., unemployment, home ownership, engagement in higher education) showed that in spite of many integration programs, the Dutch might be viewed as lagging behind the Americans in integration. However, this conclusion is based upon aggregated statistics across all three of the Dutch immigrant populations compared to the largely regular us immigrant population. Better breakdowns of Dutch immigrant groups and studies of factors facilitating or impeding integration are needed before one could conclude that Dutch integration efforts are ineffective or counterproductive.

In both the Netherlands and the us, a number of social programs for disadvantaged native minorities are available to immigrants; these (e.g., bilingual education, supplementary money for schools in poor neighborhoods, job training programs) often are major sources of integration. What is not known is the extent to which these general social programs are effectively designed for the specific needs of immigrants. For such programs with a heavy proportion of immigrant use, needs assessments and evaluations could help illuminate where integration could be made more efficient.

\section{Immigration and integration policy should be linked more closely}

The relationship between immigration and integration policy works in two directions. On the one hand, a successful integration policy demands a degree of restriction in immigration policy. The larger the immigration flows, the more difficult it will be for the responsible agencies to manage the integration of the new immigrants.

On the other hand, an integration policy demands that those who arrive in the Netherlands are rapidly given a clear statement of their resident status, so that the integration process is not delayed or interrupted. Furthermore, integration policy can make an important contribution to the long-term objectives of immigration policy by ensuring that immigrants become and remain employable on the labor market (Doormerik 1997).

The interconnecting nature of these two forms of policy further implies that it would seem desirable from an organizational point of view to link them. Both in the Netherlands and the us, immigration and integration are managed by different (sets of) organizations. A closer linking of immigration and integration policy would, in our view, improve the potential for policy planning, especially in the field of integration.

\section{Regular immigrants}

The Dutch and the Americans approach the issue of regular immigrants from slightly different perspectives, but in the end, there are many similarities in the policies that are employed in their immigration and integration. In both countries, the entry of regular immigrants is highly regulated. The us uses a system of quotas, 
while the Netherlands has strict sets of qualifying requirements (except for immigration from European Union countries under the auspices of the free movement of people within the EU). For both countries, qualifications are for the most part assessed before the candidate enters the country. Because most regular immigrants arrive with employment in hand or a family network to support them, immediate steps for integration take a secondary role. Regular immigrants are generally not viewed as social problems in either country - at least status as an immigrant is not viewed as an element of the problem.

The recent debate in the Netherlands on the use of immigration policy as a tool to attract needed human capital (critical skills) has already yielded some important policy initiatives, such as relaxing the entry of skilled labor in areas of acute demand. This is indeed an adoption of the us. policy regarding the immigration of skilled labor. Perhaps, what is needed is a consolidation of this policy through enhancing and streamlining the ways in which it is implemented (e.g. through quotas, auctions, etc.). This is in order to make it more of a core policy for attracting talent rather than an ad hoc policy in response to an ad hoc situation. Furthermore, refocusing attention on labor immigration might make immigration movements more controllable. As the regular routes to labor immigration become clearer, labor demand outside those routes could decrease, and the number of illegal immigrants or falsely claiming asylum seekers might decline.

Although Dutch foreign and security policy affects migratory flows, the Dutch external relations apparatus does not appear to have a direct function with respect to immigration policy. Whereas the country's size limits the possibilities in this field, we would still suggest that more explicit integration of the 'shaping' factor (a direction the us State Department seems to be taking) in overall immigration policy, and in the country's (and European) foreign policy in particular, could be of some interest to Dutch policymakers. One such important area where policy can be advanced is cooperation with the countries of origin. This could be done through Dutch and/or EU external policies. Cooperation can include overseas development aid and other policies to stimulate: economic cooperation, technology transfer, respect for human rights, education, and a responsible use of natural resources. Intelligent use of all the available external policy instruments (diplomatic, economic and multilateral initiatives) will lead to a more comprehensive immigration policy in the Netherlands.

Many people come to both the Netherlands and the us for a temporary stay of several years duration, either to attend educational institutions or to fill critical jobs. Some of these people desire to remain and become immigrants. The us has a varied set of policies regarding such people. For example, students who come to the us under the auspices of a Fulbright or other federally-funded scholarship are obliged to leave the us after obtaining their degrees, but students pursuing an identical course of study who are supported by their home countries may apply for permanent residence status as their studies end. The $\mathrm{H}-1$ temporary work visa 
holders may apply for permanent EB status once they are in the us; indeed a large proportion of them do so. In general, there is an attitude of implicit encouragement for temporary valued foreigners to stay in the us. The Netherlands has a different set of policies. On the one hand it has no formal length of stay for people who come to the Netherlands to work, but student visas are difficult to translate into work permits. Very much unlike the us, the Netherlands has a deliberate return policy, encouraging foreigners to return to their home countries. The reasons for the return policy can be varied. On the one hand, sending people who are burdens on the Dutch welfare system home with benefits might lower the total costs of social support. On the other hand, a mindfulness of the negative effects of 'brain drain' on source countries might lead to incentives for people who hone their skills in the Netherlands to return home. What is true of both countries is that the policies regarding who should or should be encouraged to return home are inconsistent; a rethinking of these policies would probably be of benefit.

\section{Asylees and refugees}

Compared to the us, the Netherlands admits many more refugees and asylum seekers. Caring for these immigrants is therefore the dominant issue in the Dutch immigration debate, and a number of the integration policy tools have been formulated with this group specifically in mind. As we noted earlier, the Dutch return policy appears to be in part a reflection of this attitude - after immigrants have been brought to a standard of well-being in the Netherlands, perhaps they and the Dutch are better off if this well-being is retransferred to the native country.

The federal government of the us provides more guidance and services for the integration (or at least the temporary care) of asylees and refugees than for any other population of immigrants. This said, the American effort falls far short of that of the Netherlands. However, given the relative size of the proportion of asylees and refugees in the total immigration in the two countries, we are hesitant to recommend that either can provide exemplary practices for the other.

It is widely viewed that some people seek refugee or asylum status in order to immigrate to the Netherlands because other avenues for immigration are not open to them. Dutch policy holds - appropriately in our view - that the entry of asylees and refugees should not be linked to the immigration needs of the receiving society, nor should it be restricted by any problems of reception capacity; policy should remain a reflection of the humanistic tradition of the Dutch society and should not be confused with other immigration policies. However, in view of the perceived problem, there is a need for a better understanding of the links between asylees and refugees on the one hand and regular immigration on the other hand (see above). As discussed earlier, keeping asylum as a dominant 'port of entry' to the Netherlands risks undermining asylum laws and makes them fall more under the pressure of abuse. A more comprehensive regular immigration policy will help restoring the integrity of asylum and refugee policies in the country. 


\section{Illegal immigrants}

The question of illegal immigration dominates the us. debate. Each year, more than one and a half million people are caught attempting to enter the us; even if border enforcement is 80 percent effective, more than 25 percent of immigrants are illegal. Expenditures for controlling illegal entry dominate the budget of the INS and are growing. Integration opportunities for illegal immigrants in the us are very few; schooling for children stands out as the most prominent one. In the Netherlands, illegal immigration is a lesser concern, but not entirely absent. In recent years, the problem slowly seems to gain prominence. But as of the present writing, there are no firm figures on the extent of illegal immigration. Predicting the extent of illegal immigration and controlling it pose difficulties for the Dutch government, and the us experience offers more in the way of negative object lessons than practices to alleviate the problem. Enforcement efforts are hampered by the openness of Dutch borders to Schengen countries, so they are largely internal, through checks of legal residence registration and employment. Resistance in such efforts are to be expected, as employers resist discovery of possibly illegal workers, families conceal illegal relatives, and society is unwilling to tolerate a level of interference that would be necessary to be highly effective (e.g., verifying the status of all children in schools).

\section{The limits to immigration and integration policy}

Immigration and integration policy react to external developments that are difficult, if not impossible to control. In the conduct of our research, several developments were mentioned during the interviews or found in the literature that might lead to reconsiderations of the us and Dutch immigration and integration policies. Examples of such developments are:

- $\quad$ the state of the world: the number of people applying for admission to a specific country is strongly influenced by the number and size of armed conflicts, natural disasters, hunger, or turbulent political instabilities in the world. This may affect immigration policies, such as the admission criteria, which may in its turn effect integration policies, such as the number of language courses provided.

- economic developments: the economies of most countries with a positive net migration are currently doing very well. A period of economic downturn might lead to reconsideration of the practices and principles of both admissions policies and efforts to integrate newcomers.

- pace of European unification: increasing European integration, both in terms of number of countries and supranational authority, leads to questions with respect to the division of responsibilities for immigration and integration. It needs to be decided what should be done at which level and how much variation between the individual member states is acceptable. As we inferred earlier, part-measures may be less effective than either the status quo or largescale changes. Additionally, we note that increasing European unification will have effects on the definition of what constitutes 'immigration'. 
- aging of the population: the European Commission estimates that the EU working population will start to fall in the next ten years and decrease from 225 million people in 1995 to 223 million in 2025. During the same period, the number of people greater than 65 years of age will increase from 15 to 22 percent of the population. ${ }^{1}$ This might lead to a situation in which there are not enough workers to pay for retired people's pensions.

Current immigration policies do not only affect current integration processes, but also have an effect on future integration processes. Therefore, it would be wise to consider possible external developments when defining immigration and integration policies.

\section{Toward the assessment of immigration and integration policies}

Although both countries have done remarkably little systematic evaluation of the effectiveness or efficiency of various immigration-related policies, there appear to be more holes in the state of the art on the impact of immigration in the Netherlands than in the Us. In part this is because the us has a strong cost/benefit character to its policy debates. Many us studies have tried to quantify the real costs of the 'new Americans' for us society - whether demographic, social, economic, political or fiscal, and these quantitative results enter the policy debate. In the Netherlands, such cost/benefit analyses play a secondary role in the debate to cultural and identity issues; as a consequence, analyses of the consequences of policy are less influential and fewer in number.

Both the us and the Netherlands have experienced an explosion in public expenditures on immigration. In both countries, these expenditures have been attempts to deal with backlogs in processing of immigrants and perceived ineffectiveness in enforcement against illegal immigrants. Surprisingly enough, there are remarkably few studies on the effectiveness and the efficiency of those expenditures. Although the us General Accounting Office (some 39 reports in the last 5 years) and the Algemene Rekenkamer (some 5) have examined some various aspects of immigration policy, there exist few yardsticks to evaluate the effectiveness of expenditures in immigration policy. ${ }^{2}$ The analyses that have been performed suggest that the increased expenditures have not produced a commensurate improvement in performance in either country.

The meaning of integration is subject to differences of opinion. There are no commonly accepted measures of successful integration. A broad definition of successful integration would be that it is no longer possible to distinguish the immigrant population from the native population. Integration has both social-structural (such as education, employment, social welfare and housing) and social-cultural dimensions (such as acceptance, discrimination, and political participation). As the various integration policies affect different dimensions of integration at the same time, it is very difficult to measure the effects of single policies. Our analysis showed that a one-to-one matching of policies and outcomes was not possible. This is not only 
because of context effects, but because adequate information for teasing out likely effects of single policies from the combined effects of the entire package of policies is not possible.

Another complicating factor is that integration takes place over a generation at a minimum. Integration is, by definition, a process that cannot take place from one day on the next. Therefore, it is difficult to determine after which period of time the effectiveness of integration policy should be assessed. Both the United States and the Netherlands face a continuous and ever more diverse influx of immigrants and successful integration of these immigrants cannot be expected on short term. It would be valuable to develop measures for integration that could be used across countries and across generations of immigrants. Improved monitoring of integration processes in different countries might make it easier to define best practices of integration. Based on the currently available information, it is hardly possible to measure to which integration policies are effective.

We believe that the Netherlands could benefit from examining the us approach to the collection and analysis of information regarding immigration and integration, and indeed going a step further than that to develop new measurements of policy effectiveness. This effort would not only be of practical benefit in the assessment of current policy, but it would be an impetus for making more explicit what the goals of immigration and integration policy are. If policy goals are made more explicit, then the public debate can be conducted on more of a rational basis. This, in turn, can lead to the development of policy tools whose chances of success are increased. 
NOTES

$1 \quad$ Panis, C.W.A., J.A.K. Cave, E. Charlier, J.P. Kahan (1996) Life expectancy projections for European Union member countries, Delft, the Netherlands: RAND/European-American Center for Policy Analysis Report.

2 The INS has repeatedly been chided for its lack of rigorous evaluation systems. In recent years, (and especially in its FY 2001 Summary Performance Plan), the us Department of Justice has made special efforts in this field. For the relevant section of the plan, see http://www.usdoj.gov/ag/o1core4.htm. 



\title{
BIBLIOGRAPHY
}

\section{Books, articles, reports}

Algemene Rekenkamer (2000) Inburgering en taalonderwijs allochtonen, Den Haag.

Algemene Rekenkamer, Integratiebeleid etnische minderheden, Den Haag.

Arbeidsinspectie (2000) De positie van allochtonen en autochtonen in het bedrijfsleven en bij een deel van de overheid 1998, Den Haag.

Centraal Bureau voor de Statistiek (2000) Allochtonen in Nederland 200o, Voorburg/Heerlen.

Doomernik, J., R. Penninx, and H. van Amersfoort (1997) A Migration Policy for the Future: Possibilities and Limitations, Migration Policy Group/Instituut voor Migratie- en Etnische Studies, Brussels/Amsterdam.

Foblets, M.C., and B. Hubeau (1997) Nieuwe burgers in de samenleving? Burgers en inburgering in Nederland en België, Leuven/Amersfoort: Acco.

Martens, E.P., \& Y.M.R. Weijers (2000) Integratiemonitor 200o, ISEO, Rotterdam.

Ministerie van Binnenlandse Zaken en Koninkrijksrelaties (2000) Rapportage integratiebeleid etnische minderheden, Den Haag.

Ministerie van Onderwijs, Cultuur en Wetenschappen (2000, februari) Onderwijskansen: Ruimte voor kwaliteit bij de aanpak van onderwijsachterstanden, Zoetermeer,.

Ministerie van Onderwijs, Cultuur en Wetenschappen (2000, juni) Aan de slag met onderwijskansen: Gerichte aanpak onderwijsachterstanden, Zoetermeer.

Sociaal en Cultureel Planbureau (1999) Rapportage minderheden 1999, Den Haag.

Tweede Kamer, Kansen pakken, kansen krïgen.

Werkverband Periodieke Rapportage Bevolkingsvraagstukken (2000) Bevolkingsvraagstukken in Nederland anno 2000 , Nederlands Interdisciplinair Demografisch Instituut, Rapport no. 58, Den Haag.

\author{
Websites \\ www.cbs.nl \\ www.foquz.nl/allochtonen \\ www.immigratiedienst.nl \\ www.minbzk.nl \\ www.minjust.l \\ www.minocw.nl \\ www.minszw.nl \\ www.nidi.nl \\ www.rekenkamer.nl \\ www.vluchtelingenwerk.nl
}




\section{Books, articles, reports}

Bean, F.D., Edmonston B., and J. Passel (eds.) (1990) Undocumented Migration to the United States, JRI-07, RAND and the Urban Institute, Washington DC.

Camarota, S.A. (1999) Immigrants in the United States - 1998. A Snapshot of America's Foreign-born Population, Center for Immigration Studies.

Goldsborough, J. (2000) ‘Out-of-Control Immigration', Foreign Affairs, Council of Foreign Relations, Washington DC, September/October.

Luciani, G (ed.) (1993) Migration Policies in Europe and the United States, Dordrecht, Netherlands: Kluwer Academic Publishers.

McCarthy, K. and G. Vernez (1997) Immigration in a Changing Economy -California's Experience, Center for Research Immigration Policy. RAND MR-854, Santa Monica, CA.

Rolph, E. (1991) Immigration Policies-Legacy from the 1980s and Issues for the 1990s, Program for Research on Immigration Policy, RAND, Santa Monica, CA.

Smith, J.P., and B. Edmonston (eds.) (1997) The New Americans: Economic, Demographic, and Fiscal Effects of Immigration, Washington DC: National Academy Press.

Statistical Yearbook of the Immigration and Naturalization Service (1997) Immigration and Naturalization Service, us Government Printing Office, Washington DC, January.

The Triennial Comprehensive Report on Immigration (1999) Us. Department of Justice, Immigration and Naturalization Service, and us Department of Labor, us Government Printing Office, Washington DC.

Tumlin, K.C., W. Zimmerman, and J. Ost (1999) State Snapshots of Public Benefits for Immigrants: A Supplemental Report to "Patchwork Policies", The Urban Institute, Occasional Paper No. 24 Supplemental report, Washington DC.

Vernez. G. and L. Mizell (2000) Monitoring the Education Progress of Hispanics, PM-1045, Santa Monica, CA, March.

Vernez. G. and A. Abrahamse (1996). How Immigrants Fare in US Education. Institute on Education and Training, MR-718-AMF, Santa Monica, CA.

Vernez, G. R. Krop and C.P. Rydell (1999) Closing the Education Gap, RAND MR1036-EDU, Santa Monica, CA.

Vernez, G. and K. F. McCarthy (1996) The Costs of Immigration to TaxpayersAnalytical and Policy Issues. RAND MR-705-FF/IF, Santa Monica, CA.

Vernez, G. (1994) Comparison of Immigration and Refugee Policy Regimes Among Major Western Nations, RAND DRU-757-FF/CC, Santa Monica, CA, June.

Vernez, G. (1999) Immigrant Women in the Us Workforce, New York: Lexington Books. 
Zimmerman, W., and K.C. Tumlin (1999) Patchwork Policies: State Assistance for Immigrants under Welfare Reform, The Urban Institute, Occasional Paper No. 24, Washington DC.

\section{Websites}

www.bls.gov

www.census.gov

www.ed.gov

www.hhs.gov

www.hud.gov

www.house.gov

www.ins.gov

www.mla.org

www.ncbe.gwu.edu

http://thomas.loc.gov 



\section{LIST OF ABBREVIATIONS}

General
EEA
EU
FY
NAFTA
UNECE
UNHCR
US
WRR

\section{United States}

APIS

ASC

BBA

$\mathrm{BCI}$

EB

ESL

EWI

IIRIRA

INA

INS

INTASC

IRCA

IRP

ISIS

JTPA

JPATS

LEP

OVAE

PRWORA

QRT

SENTRI

SSI

TANF

WIN

\section{Netherlands}

\section{ABW}

AKW

AMA'S

ANW

AOW

AWBZ

COA

CUMI

$\mathrm{HBO}$

IHS

IND

MTV

MVV
Economic European Area

European Union

Fiscal Year

North American Free Trade Agreement

United Nations Economic Council of Europe

United Nations High Commission for Refugees

United States

Wetenschappelijke Raad voor het Regeringsbeleid

(Netherlands Scientific Council for Government Policy)

Advanced Passenger Information System

Application Support Center

Balanced Budget Act

Border Co-ordination Initiative

Employment Based preferences

English as a Second Language

Entry Without Inspection

Illegal Immigration Reform and Immigration Responsibility Act

Immigration and Nationality Act

Immigration and Naturalization Service

Interstate New Teacher Assessment and Support Consortium

Immigration and Reform and Control Act

Institutional Removal Program

Integrated Surveillance Intelligence System

Job Training Partnership Act

Justice Prisoner and Alien Transportation System

Limited English Proficiency

Office of Vocational and Adult Education

Personal Responsibility and Accountability Act

Quick Response Team

Secure Electronic Network for Travelers Rapid Inspection

Supplemental Security Income

Temporary Assistance Needy Families

Work Incentive

Algemene BijstandsWet (welfare act)

Algemene KinderbijslagWet (child support act)

Alleenstaande Minderjarige Asielzoekers (asylees under the age of 18 present without their family)

Algemene NabestaandenWet (surviving relatives allowance act)

Algemene OuderdomsWet (old age pension)

Algemene Wet Bijzondere Ziektekosten (exceptional medical expenses act)

Centraal Orgaan Opvang Asielzoekers (reception center for asylees)

Culturele minderheid (cultural minority)

Hoger Beroeps Onderwijs (high-end vocational education

Individuele HuurSubsidie (rent assistance)

Immigratie- en Naturalisatiedienst (immigration and

naturalization service)

Mobiel Toezicht Vreemdelingen (mobile oversight of foreigners)

Machtiging tot Voorlopig Verblijf (authorization for temporary

stay) 
NT2

OALT

OC\&W

SAMEN

VTV

VVTV

WAO

WAV

WIN

WIW

WO

WW

ZFW
Nederlands als Tweede Taal (Dutch as a second language) Onderwijs in Allochtone Levende Talen (education in nonwestern foreign languages)

Ministerie van Onderwijs, Cultuur en Wetenschappen (Dutch Ministry of Education, Culture and Science)

Stimulering Arbeidsdeelname Minderheden (stimulation of labor participation of ethnic minorities)

Vergunning Tot Verblijf (residence permit)

Voorlopige Vergunning Tot Verblijf (temporary residence

permit)

Wet op de ArbeidsOngeschiktheid (disability benefits act)

Wet Arbeid Vreemdelingen (foreign Labor act)

Wet Inburgering Nederlanders (integration of immigrants act)

Wet Inschakeling Werkzoekenden (employability for job

seekers act)

Wetenschappelijk Onderwijs (scientific education)

Werkloosheidswet (unemployment benefits act)

ZiekenFondsWet (public health insurance act) 